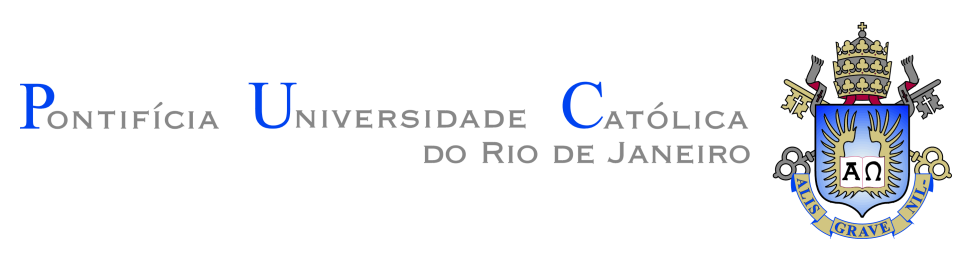

Clarissa Costalonga e Gandour

Forest Wars: A Trilogy on Combating Deforestation in the Brazilian Amazon

Tese de Doutorado

Thesis presented to the Programa de Pós-graduação em Economia of PUC-Rio in partial fulfillment of the requirements for the degree of Doutor em Economia.

Advisor: Prof. Juliano Junqueira Assunção 


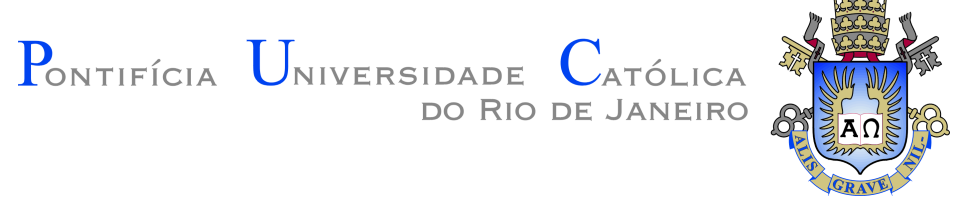

Clarissa Costalonga e Gandour

\section{Forest Wars: A Trilogy on Combating Deforestation in the Brazilian Amazon}

Thesis presented to the Programa de Pós-graduação em Economia of PUC-Rio in partial fulfillment of the requirements for the degree of Doutor em Economia. Approved by the undersigned Examination Committee.

Prof. Juliano Junqueira Assunção

Advisor

Departamento de Economia - PUC-Rio

Prof. Alexander Pfaff

Sanford School of Public Policy - Duke University

Prof. Carlos Augusto Klink

Departamento de Ecologia - UnB

Prof. Eduardo Augusto de Souza-Rodrigues

Department of Economics - University of Toronto

Prof. Francisco Junqueira Moreira da Costa

Escola Brasileira de Economia e Finanças - FGV

Prof. Augusto Cesar Pinheiro da Silva

Vice Dean of Graduate Studies

Centro de Ciências Sociais - PUC-Rio

Rio de Janeiro, September 3rd, 2018 
All rights reserved.

\section{Clarissa Costalonga e Gandour}

Completed her Bachelor of Arts degree in Economics from Pontifícia Universidade Católica do Rio de Janeiro in 2009, having spent one year in the University of California, Berkeley. Obtained her Master of Science degree in Economics from Pontifícia Universidade Católica do Rio de Janeiro in 2011. Works as a Senior Researcher in Climate Policy Initiative / Núcleo de Avaliação de Políticas Climáticas da PUC-Rio, where she conducts applied research on conservation policy evaluation.

Bibliographic data

Gandour, Clarissa Costalonga e

Forest Wars: A Trilogy on Combating Deforestation in the Brazilian Amazon / Clarissa Costalonga e Gandour; advisor: Juliano Junqueira Assunção. - Rio de Janeiro: PUC-Rio, Departamento de Economia, 2018.

120 f: il. color. ; $29,7 \mathrm{~cm}$

Tese (doutorado) - Pontifícia Universidade Católica do Rio de Janeiro, Departamento de Economia, 2018.

Inclui bibliografia.

1. Economia - Teses. 2. Desmatamento. 3. Regeneração. 4. Monitoramento e Aplicação da Lei. 5. Áreas Protegidas. 6. Externalidades. I. Assunção, Juliano Junqueira. II. Pontifícia Universidade Católica do Rio de Janeiro. Departamento de Economia. III. Título. 


\section{Acknowledgments}

To Juliano Assunção, whom I have greatly admired as a researcher for over a decade, for giving me the opportunity to rediscover that I belong in applied research;

To the members of the Examination Committee, for their extremely valuable contributions, but even more so for sharing my enthusiasm for the topic;

To Climate Policy Initiative and the CAPES Foundation Program for Academic Excellence, for the generous financial support;

To Dalton Valeriano, Luis Maurano, and Marcos Adami, from Brazil's National Institute for Space Research (Inpe), for so kindly and patiently helping an economist navigate the wonders of remote sensing data;

To Cristina Leme, for tirelessly answering my legal doubts in what were always enlightening and engaging conversations;

To my very own Dr. Nefario, Ana "Aninha" Ribeiro, and my minions, Diego Menezes, Helena Arruda, João Vieira, and Tomás Valle, for their sincere interest, remarkable dedication, and unquenchable desire to learn;

To the friends Amanda Schutze, Larissa Faria, and Maína Celidônio, for being there when I needed the wisdom of soothing words, firm reality checks, and tight hugs;

To my family, for their unwavering support, and specially to my parents, for setting the foundations that allowed me to get to where I am today;

To Bonnie Tyler, for teaching me more about myself than I ever thought possible coming from wagging tails and furry snuggles;

To Vinícius Segura, for everything. Again. 


\section{Abstract}

Gandour, Clarissa Costalonga e; Assunção, Juliano Junqueira (Advisor). Forest Wars: A Trilogy on Combating Deforestation in the Brazilian Amazon. Rio de Janeiro, 2018. 120p. Tese de doutorado - Departamento de Economia, Pontifícia Universidade Católica do Rio de Janeiro.

This dissertation assesses policy effects of conservation efforts adopted within the scope of the federal action plan to combat Amazon deforestation in Brazil. Chapter 1 provides a description of key policy changes and surveys the associated effectiveness literature. It finds evidence that supports the action plan's efficacy in reducing aggregate deforestation levels, but notes that indirect impacts of conservation policies have received little attention. The remaining chapters explore direct and indirect impacts of action plan policies using a georeferenced ten-year panel dataset to account for spatial dynamics. Chapter 2 tests whether legal territorial protection grants actual protection against advancing deforestation. Using a measure of neighboring clearing activity to capture local deforestation risk, the analysis compares forest clearing outcomes in unprotected and protected territory under equivalent deforestation pressures. The empirical strategy draws on the dataset's raster structure to mitigate concerns of potentially confounding unobservables via the use of raster cell fixed effects. Results document protection's efficacy in a high-risk context, with significantly less forest being cleared in protected cells than in unprotected ones. Yet, although protected territory effectively shields vegetation under its domain from advancing deforestation, it appears to deflect clearings to unprotected areas. Protection therefore affects regional forest clearing dynamics, but not the overall level of deforestation. Chapter 3 investigates whether changes in tropical regeneration constituted a spillover effect from law enforcement targeting forest loss. Secondary vegetation was vulnerable during the first decade of the action plan, which neither promoted tropical regeneration nor sought to conserve existing secondary vegetation. Moreover, regeneration remained undetected in satellite-based forest monitoring systems. Still, during this period, the extent of Amazon secondary vegetation increased by nearly 7 million hectares. The final part of this dissertation examines whether law enforcement contributed to this growth, albeit unintentionally. The empirical 
strategy uses a ten-year cross-sectional difference in observed regeneration outcomes to address the intrinsically time-consuming nature of this phenomenon. Results are shown to be robust to the inclusion of a host of raster cell-level controls, mitigating concerns about omitted variable bias. Findings indicate that the intensity of enforcement in a location's close surroundings is associated with both increased probability of secondary vegetation expansion and increased area of secondary vegetation in that location. This lends support to the hypothesis that environmental offenders, once faced with a higher perceived cost of engaging in illegal deforestation, abandoned the area they were operating in and thereby allowed a natural process of forest regrowth to occur. The spillover effect of enforcement on regeneration appears largest in places that have undergone neither too much nor too little deforestation: in the former, forest clearings and non-forest land use are probably more consolidated, and regrowth is therefore less likely; in the latter, there is still relatively little area for the forest to grow back in. Counterfactual exercises shed light on the magnitude of this effect. An enhanced satellite-based monitoring system for targeting enforcement would have resulted in nearly 300 thousand additional hectares of secondary vegetation.

\section{Keywords}

Deforestation; Regeneration; Monitoring and Law Enforcement; Protected Areas; Spillovers. 


\section{Resumo}

Gandour, Clarissa Costalonga e; Assunção, Juliano Junqueira. Guerra na Floresta: Uma Trilogia sobre o Combate do Desmatamento na Amazônia. Rio de Janeiro, 2018. 120p. Tese de Doutorado - Departamento de Economia, Pontifícia Universidade Católica do Rio de Janeiro.

Esta tese avalia políticas de conservação adotadas no âmbito do plano de ação federal para combate ao desmatamento na Amazônia brasileira. O Capítulo 1 descreve as principais mudanças institucionais e discute suas avaliações de efetividade. A revisão de literatura corrobora a eficácia das medidas para a redução do desmatamento, mas indica também que efeitos indiretos das políticas de conservação foram pouco estudados. Os demais capítulos conduzem análises empíricas sobre efeitos diretos e indiretos dessas políticas, utilizando um painel de dez anos de dados georreferenciados para contemplar dinâmicas espaciais ao longo do tempo. O Capítulo 2 testa se proteção territorial legal confere real proteção contra desmatamento. Tomando a intensidade do desmatamento no entorno de uma área como uma medida do risco de desmatamento local, o estudo compara a perda florestal em territórios protegidos e não protegidos sujeitos a riscos de desmatamento equivalentes. Aproveitando o formato raster dos dados, a estratégia empírica inclui efeitos fixos de célula para mitigar preocupações sobre possível viés oriundo de não-observáveis. Os resultados documentam a eficácia da proteção: células protegidas tiveram significativamente menos perda florestal do que células não protegidas, mesmo quando expostas ao mesmo risco de desmatamento. Contudo, ainda que o território protegido sirva como um escudo contra o avanço do desmatamento, a perda florestal por ele desviada parece seguir para áreas não protegidas. A proteção, portanto, afeta a dinâmica regional do desmatamento, mas não seu nível agregado. O Capítulo 3 investiga se variações na regeneração tropical configuram uma externalidade de medidas de aplicação da lei voltadas para o desmatamento. A vegetação secundária esteve vulnerável durante a primeira década do plano de ação, que não direcionou esforços para a promoção da regeneração tropical e tampouco para a conservação de vegetação secundária existente. Além disso, a regeneração permaneceu invisível ao sistema de monitoramento da floresta. Mesmo assim, a área de vegetação secundária na Amazônia 
aumentou em 7 milhões de hectares durante esse período. A última parte desta tese averigua se a aplicação da lei contribuiu para esse fenômeno, ainda que não intencionalmente. Os resultados são robustos à inclusão de uma série de controles em nível da célula, que mitigam preocupações sobre viés de variável omitida. A análise indica que uma maior intensidade de aplicação da lei no entorno de um local está associada a maior probabilidade de expansão da vegetação secundária e também maior área por ela coberta naquele local. Isso apoia a hipótese de que infratores ambientais, diante dos maiores custos associados à atividade ilegal, abandonaram as regiões onde operavam e, assim, permitiram que ocorresse um processo natural de regeneração. A força dessa externalidade varia conforme o grau de desmatamento local: regiões mais desmatadas provavelmente abrigam atividades não florestais mais consolidadas, dificultando o ressurgimento da floresta; regiões menos desmatadas ainda oferecem uma área relativamente pequena para regeneração em escala. Exercícios contrafatuais ilustram a magnitude desse efeito, mostrando que melhorias no sistema de monitoramento do desmatamento resultariam em quase 300 mil hectares adicionais de vegetação secundária.

\section{Palavras-chave}

Desmatamento; Regeneração; Monitoramento e Aplicação da Lei; Áreas Protegidas; Externalidades. 


\section{Table of Contents}

$\begin{array}{ll}\text { Introduction } & 14\end{array}$

Chapter 1 A New Plan 16

1.1 Amazon Deforestation and the Action Plan 16

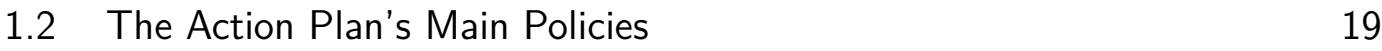

$\begin{array}{ll}\text { 1.2.1 Monitoring and Law Enforcement } & 19\end{array}$

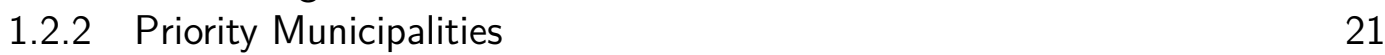

$\begin{array}{ll}1.2 .3 & \text { Conditional Rural Credit } \\ 1.2 .4 & 23\end{array}$

1.2.4 Protected Territory 24

1.2.5 Environmental Registry 25

1.2.6 Other Contributions 27

1.3 Policy and Academic Challenges 29

Chapter 2 The Deforestation Menace 32

2.1 Introduction 32

2.2 Institutional Context 34

2.2.1 Amazon Deforestation as an Illegal Activity 35

2.2.2 Monitoring and Law Enforcement 36

2.2.3 Protected Territory 36

2.2.4 Rationale for Individual Land Use Decision 40

2.3 Empirical Strategy $\quad 42$

2.4 Data 44

2.4.1 Main Variables $\quad 44$

2.4.2 Controls 45

2.4.3 Descriptive Statistics 46

2.5 Results 48

2.5.1 Main Results: Pressure and Protection 49

2.5.2 Robustness: Extended Neighborhoods 51

2.5.3 Heterogeneity: Protection Type and Transportation Infrastructure $\quad 52$

2.5.4 Counterfactual Exercises: Aggregate Deforested Area 56

2.6 Final Remarks $\quad 59$

$\begin{array}{lll}\text { Chapter } 3 \text { The Forest Awakens } & 60\end{array}$

$\begin{array}{ll}3.1 \text { Introduction } & 60\end{array}$

3.2 Institutional Context 64

3.3 Empirical Strategy 66

$\begin{array}{lll}3.3 .1 & \text { Identification } & 67\end{array}$

$\begin{array}{ll}\text { 3.3.2 Implementation } & 68\end{array}$

$\begin{array}{ll}3.4 \text { Data } & 71\end{array}$

$\begin{array}{lll}3.4 .1 & \text { Main Variables } & 71\end{array}$

$\begin{array}{ll}3.4 .2 \text { Controls } & 72\end{array}$

$\begin{array}{lll}3.4 .3 & \text { Descriptive Statistics } & 73\end{array}$

$\begin{array}{lll}3.5 & \text { Results } & 76\end{array}$

3.5.1 Main Results: Policy Spillovers 76 
3.5.2 Robustness: Alternative Dependent Variables and Samples 81

3.5.3 Robustness: Additional Controls $\quad 85$

3.5.4 Counterfactual Exercises: Monitoring Capacity 89

3.6 Final Remarks 94

$\begin{array}{ll}\text { Bibliography } & 95\end{array}$

$\begin{array}{ll}\text { Appendix A Spatial Setup } & 107\end{array}$

A.1 Georeferenced Raster Structure 107

$\begin{array}{ll}\text { A.2 Geographical Regions } & 108\end{array}$

$\begin{array}{ll}\text { Appendix B Data Sources and Descriptions } & 109\end{array}$

B.1 Land Cover and Land Use 109

B.1.1 Measuring Deforestation 109

B.1.2 Monitoring Deforestation and Degradation 113

B.1.3 Mapping Land Use in Deforested Areas 114

$\begin{array}{lll}\text { B.2 Protected Territory } & 115\end{array}$

$\begin{array}{ll}\text { Appendix C Data Construction } & 117\end{array}$

$\begin{array}{ll}\text { C.1 Non-Decreasing Secondary Vegetation } & 117\end{array}$ 


\section{List of Figures}

Figure 1.1 Brazilian Amazon Deforestation, Historical Through $2004 \quad 17$

Figure 1.2 Brazilian Amazon Deforestation, Annual Rate 2000-2014 18

Figure 2.1 Extent of Protected Territory, 2004-2014 37

Figure 2.2 Deforestation and Protection Before the Action Plan 39

Figure 2.3 Targeted Expansion of Protected Territory 41

Figure 2.4 Amazon Spatial Boundaries and Sample Definition 46

Figure 2.5 Sample Protection and Deforestation 47

Figure 2.6 Impact Accounting for Distance to Transport Infrastructure 56

Figure 2.7 Counterfactual Exercise - No Protection 57

Figure 2.8 Counterfactual Exercise - No Protection, by Type 57

Figure 3.1 Brazilian Amazon Deforestation and Regeneration, 2000-2014 61

Figure 3.2 Law Enforcement Spillover on Regeneration 80

Figure 3.3 Density Histogram for Difference in Secondary Vegetation Area 82

Figure 3.4 Robustness - Alternative Dependent Variables 84

Figure 3.5 Robustness - Alternative Samples, Probability-Based Outcome 87

Figure 3.6 Robustness - Alternative Samples, Area-Based Outcome 88

Figure 3.7 Counterfactual Exercise - Enhanced Monitoring System 92

Figure 3.8 Counterfactual Exercise - No Monitoring System 93

Figure A.1 Raster Grid, Cell, and Minicell 108

$\begin{array}{lll}\text { Figure A.2 Raster Cell Neighborhoods } & 108\end{array}$

Figure B.1 Satellite Systems for Detecting Forest Disturbances 110

Figure B.2 Detected Forest Disturbances 112

Figure B.3 Regeneration by Amazon State, 2014

Figure C.1 Satellite-Based Classification of Regeneration 118

Figure C.2 Non-decreasing Secondary Vegetation Classification Algorithm 120 


\section{List of Tables}

Table 2.1 Sample Protection and Deforestation by Year 46

Table 2.2 Descriptive Statistics for Regression Variables 48

Table 2.3 Neighborhood Clearing Activity and Local Deforestation Outcomes 50

Table 2.4 Protected Territory as a Shield to Advancing Deforestation 51

Table 2.5 Robustness - Extended Neighborhoods 52

Table 2.6 Heterogeneity - Protection Types 53

Table 2.7 Heterogeneity - Distance to Transport Infrastructure 55

Table 2.8 Counterfactual Exercise - No Protection, Full Sample Impact 58

$\begin{array}{lll}\text { Table 3.1 Sample Deforestation and Regeneration } & 74\end{array}$

Table 3.2 Descriptive Statistics for Regression Variables 75

Table 3.3 Catchment Area for Law Enforcement Spillover on Regeneration 78

Table 3.4 Law Enforcement Spillover on Regeneration 79

Table 3.5 Robustness - Alternative Dependent Variables 83

Table 3.6 Deforestation and Regeneration Across Alternative Samples 85

Table 3.7 Robustness - Alternative Samples 86

Table 3.8 Robustness - Additional Controls $\quad 90$

Table 3.9 Recorded Areas in Monitoring and Measuring Systems 91 


\section{Introduction}

Climate change is a topic of global relevance. Greenhouse gas emissions, the leading driver of rising temperatures, are not constrained by national borders, and are therefore a stark example of global externalities (Stern, 2008; Greenstone and Jack, 2015). With most of the increase in greenhouse gas emissions over the coming decades projected to originate in developing countries, Greenstone and Hanna (2014) state that "the planet's well-being rests on the ability of these countries to successfully enact and enforce environmental policies". Yet, they also note that weak institutional and regulatory frameworks in these same developing countries often hinder the effective implementation and enforcement of policies. Moreover, with the bulk of research on climate change and environmental policy focused on developed economies, little is actually known about effects and workings of climate policy where it currently matters most (Burke et al., 2016).

Brazil's action plan to combat Amazon forest clearings is an environmental policy that was both enacted in and entirely enforced by a developing country with large potential to contribute to global greenhouse gas emissions reductions. At the beginning of the $21^{\text {st }}$ century, the forestry sector accounted for nearly a fifth of total worldwide greenhouse gas emissions, mostly due to tropical deforestation (IPCC, 2007). The clearing of Amazon forest in Brazil played a large role in this (Hansen and DeFries, 2004; Hansen et al., 2008). Home to nearly two thirds of the Amazon Forest, the planet's largest standing tropical forest tract, the Brazilian Amazon originally extended over 400 million hectares. By the mid-2000s, Brazil had lost more than $15 \%$ of its Amazon forest area. Around this time, growing awareness that tropical forests play a fundamental role in conserving biodiversity, protecting hydrological resources, and stocking carbon pushed the fight against tropical clearings to the top of the global policy agenda (Stern, 2008; Burgess et al., 2012). Hence, in a context of historically high deforestation rates (Inpe, 2017) and mounting international pressure, Brazil launched an innovative action plan that proposed a new approach towards combating forest clearings. The plan inaugurated integrated action across government spheres and institutions, and introduced novel procedures for monitoring, environmental control, and territorial management. 
With this dissertation, I aim to take stock of action plan efficacy assessments, and propose new empirical evidence regarding policy effectiveness and spillovers. Chapter 1 provides a detailed description of the plan's main policy efforts, followed by a comprehensive survey of their empirical evaluation. This literature review offers ample evidence to support the action plan's effectiveness in reducing aggregate deforestation levels, but also reveals that the indirect impacts of action plan policies have received little attention. Chapter 2 investigates the effectiveness of protected territory, presenting empirical evidence that protection served as a shield against forest clearing pressures. Chapter 3 looks at regeneration as a spillover effect of enforcement that targeted deforestation, showing that it contributed to tropical regrowth. These findings yield relevant policy implications that could strengthen Brazil's ongoing effort to further reduce Amazon forest loss and boost tropical conservation. 


\section{Chapter 1 A New Plan}

\section{1}

\section{Amazon Deforestation and the Action Plan}

By 2004, nearly 62 million hectares of Brazilian Amazon forest had been cleared (Inpe, 2017) (see Figure 1.1). Although Brazil had been responsible for a large share of the loss of tropical vegetation observed globally through the beginning of the $21^{\text {st }}$ century (Hansen and DeFries, 2004; Hansen et al., 2008), Amazon deforestation was not only a thing of the past. The early 2000s bore witness to intense forest clearing activity, with the annual deforestation rate rising through 2004 (see Figure 1.2). During this period, Brazil stood out as the country that cleared most tropical forest, both in absolute area and as share of year-2000 forest cover (Hansen et al., 2008). Nationally, deforestation also took its toll, with forest conversion and land use change accounting for about $70 \%$ of Brazil's total annual $\mathrm{CO}_{2}$-equivalent emissions (MCTI, 2013).

Within a context of escalating deforestation rates and mounting international pressure, the Brazilian federal government sought a new approach towards combating Amazon deforestation. Thirteen key ministries were brought together under the coordination of the Presidential Chief of Staff Office to propose actions aimed at reducing tropical clearings. In mid-2004, the group presented the operational project for the Action Plan for the Prevention and Control of Deforestation in the Legal Amazon (PPCDAm). ${ }^{1}$ Comprising a large set of strategic conservation measures, the plan operated along three main pillars: territorial management and land use; monitoring and law enforcement; and promotion of sustainable practices (Casa Civil, 2004). ${ }^{2}$ These measures were to be executed as part of a collaborative effort between federal, state, and municipal governments. Although integration across numerous ministries and government spheres to combat deforestation was innovative in and of itself, the decade that followed

\footnotetext{
${ }^{1}$ The Brazilian Legal Amazon is a geopolitical administrative subdivision of the country covering Acre, Amapá, Amazonas, Mato Grosso, Pará, Rondônia, Roraima, and Tocantins states, as well as the western part of Maranhão state.

${ }^{2}$ The PPCDAm 2016-2020 operational plan added economic instruments as a fourth pillar (MMA, 2016).
} 
Figure 1.1: Brazilian Amazon Deforestation, Historical Through 2004

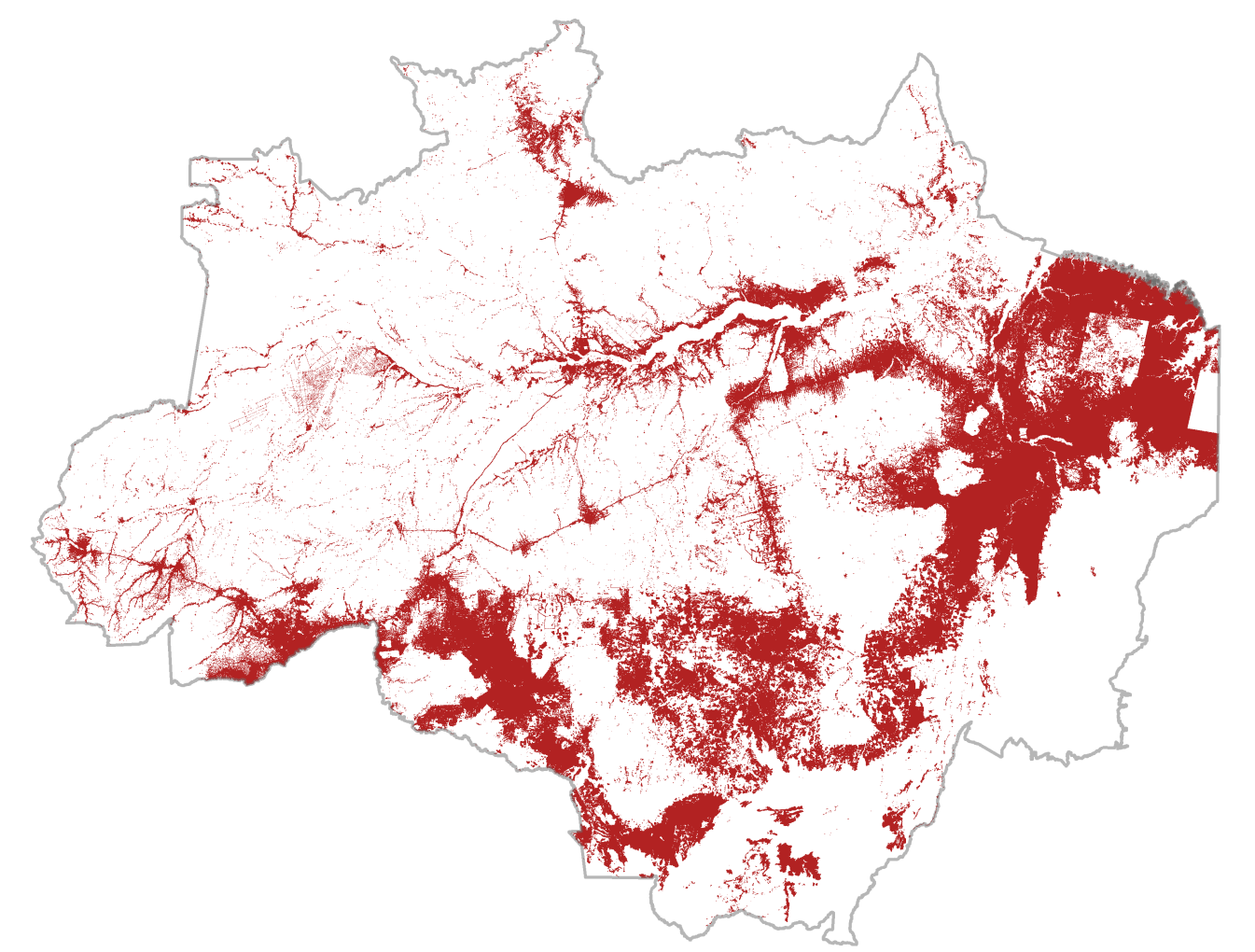

Notes: The map shows accumulated deforestation through 2004. Data sources: PRODES/Inpe (deforestation); IBGE (Legal Amazon).

the launch of the action plan saw the adoption of several novel conservation policies. Section 1.2 discusses these.

When the action plan was adopted, the economic literature had already established empirical associations between tropical deforestation and a variety of its drivers. These included, but were not limited to, population pressures, economic growth, local biophysical characteristics, infrastructure development, and agricultural prices (Cropper and Griffiths, 1994; Chomitz and Gray, 1996; Chomitz and Thomas, 2003; Foster and Rosenzweig, 2003). ${ }^{3}$ Among studies that looked specifically at the Brazilian Amazon, Pfaff (1999) was the first to assess tropical clearings by building on a theoretical microeconomic framework and using remote sensing data to empirically estimate the relative effects of different determinants of clearing activity. Yet, by the mid-2000s, existing empirical evidence remained largely centered around natural and economic drivers of tropical deforestation, with relatively little attention being given to policy's potential to curb clearings.

\footnotetext{
${ }^{3}$ See Angelsen and Kaimowitz (1999) and Barbier and Burgess (2001) for surveys of the literature through the early 2000s, and Busch and Ferretti-Gallon (2017) for a recent meta-analysis.
} 
Figure 1.2: Brazilian Amazon Deforestation, Annual Rate 2000-2014

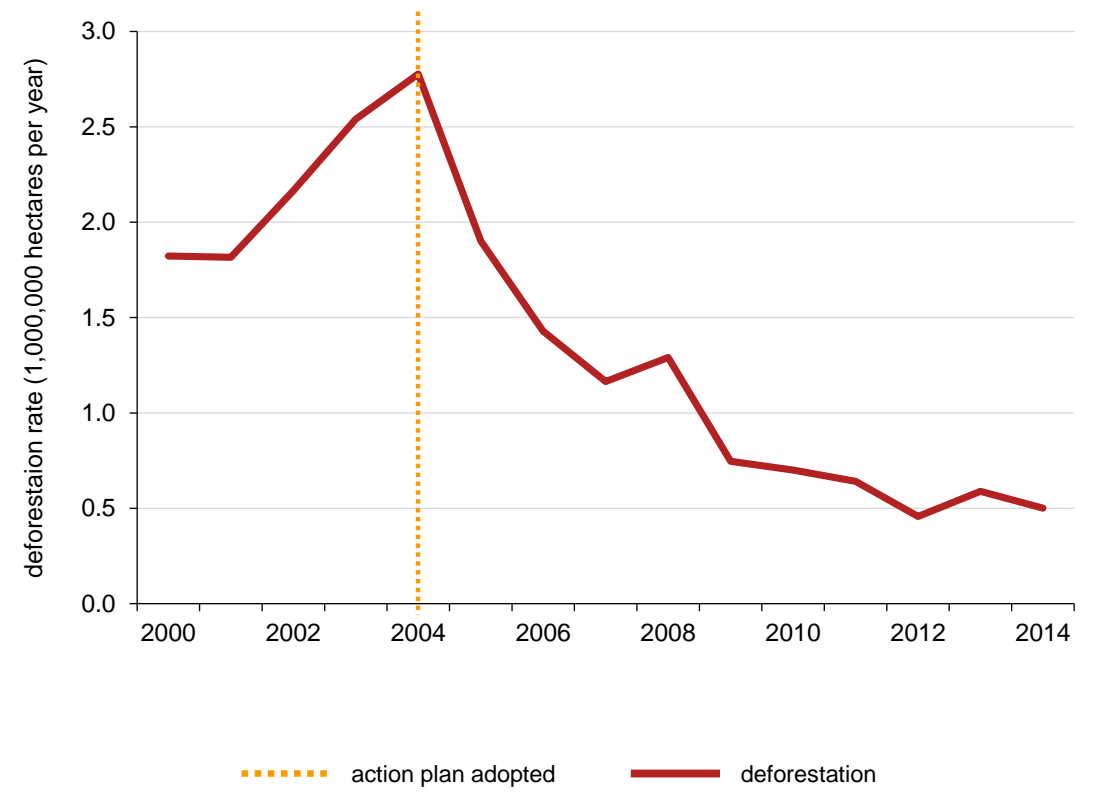

Notes: The graph plots the Brazilian Amazon annual deforestation rate and marks the year the PPCDAm was launched. Data sources: PRODES/Inpe (deforestation).

The sharp downturn in Amazon deforestation rates observed in the years following the launch of the action plan prompted a shift in research focus. Over the course of a decade, Brazilian Amazon clearing rates rapidly fell from 2.8 million hectares to about 600 thousand hectares per year (see Figure 1.2). The timing of this deforestation slowdown, which started immediately after the onset of the action plan, strongly hints at policy having played an important role. In face of such stark visual correlation, a (still) growing part of the literature started to investigate if and how policy efforts adopted within the scope of the PPCDAm contributed to the acute reduction in clearing rates. Hargrave and Kis-Katos (2013) and Assunção et al. (2015) were among the first to empirically test the action plan's impact on Amazon deforestation. Using municipality-level data, the studies document that variations in agricultural commodity prices drove observed variations in forest clearings during the early years of the PPCDAm; but both also find that conservation policy adopted from 2004 onwards significantly contributed to the deforestation slowdown. Specifically, Hargrave and Kis-Katos (2013) indicate that environmental law enforcement activity had a strong negative impact on forest clearings, while Assunção et al. (2015) assess the action plan's overall effectiveness. In the latter, the authors estimate that total Amazon deforested area through the end of the decade would have been more than twice as large had it not been for PPCDAm conservation policies. More recently, Burgess et al. (2018) 
explore spatially explicit data in a regression discontinuity design to show that stricter conservation policies contained deforestation even along Brazil's remote international Amazon borders. This, the authors argue, serves as evidence of both the action plan's role in reducing forest clearings, and the Brazilian state's capacity to influence environmental conservation in remote parts of its national territory.

\section{2}

\section{The Action Plan's Main Policies}

This section describes key policies adopted under the PPCDAm and surveys the associated effectiveness literature. It does not intend to be fully exhaustive, but rather to cover the efforts that garnered most attention from policymakers and/or academics within the first decade of the action plan.

\subsection{1}

\section{Monitoring and Law Enforcement}

Amazon deforestation can be legal if the clearing of a specific area has been duly authorized or licensed by subnational (usually state) environmental authorities in accordance with the area's land tenure regulations. ${ }^{4}$ However, the vast majority of forest areas cleared in the mid-2000s - and, in fact, still today - are done so under illegal circumstances (Börner et al., 2014; Schmitt, 2015). ${ }^{5}$ Tackling illegal clearings was thus a priority for the PPCDAm, and monitoring and law enforcement became one of the plan's three main pillars. In the plan's official evaluation, Maia et al. (2011) argue that this was, in fact, the most successful pillar from both implementation and effectiveness viewpoints through the early 2010s.

The action plan sought to strengthen monitoring and enforcement capacity in both institutional and technical spheres. From a legal standpoint, the PPCDAm promoted regulatory change. Brazil's Law of Environmental Crimes had, in 1998, already set criminal charges and applicable penalties for illegal clearings (Brasil, 1998). Yet, it was only with the passing of

${ }^{4}$ See Section 2.2.1 for a detailed description of conditions under which Amazon deforestation is legal.

${ }^{5}$ Despite a general consensus among scholars, policymakers, and members of the civil society that most Amazon deforestation activity is illegal, there is no official figure for legal versus illegal clearings. In informal conversations, law enforcement personnel have estimated that less than $10 \%$ of deforested areas in the Amazon are legal. Several ongoing efforts are expected to contribute to refining this figure in the near future. Most notably, the soonto-be universal and compulsory adoption of the Rural Environmental Registry (CAR, see Section 1.2.5) is regarded as a powerful instrument for the identification of environmental irregularities inside rural properties. The construction of the National Public Forest Registry (CNFP) by the Brazilian Forest Service (SFB) will likely also help detect irregularities in public lands. 
Presidential Decree 6,514 ten years later that directives for the administrative investigation and punishment of environmental infractions were defined in greater detail than had been previously incorporated in legislation (Brasil, 2008a). Aiming at increasing both clarity and speed of administrative processes, the decree regulated the use of penalties including fines, embargoes, and seizure and destruction of production goods, tools, and materials. It also established the public release of a list identifying landowners of areas under environmental embargo. Overall, these measures brought greater robustness and regulatory stability to administrative processes regarding environmental infractions.

Yet, it was technological innovation that enabled the major leap forward in monitoring and law enforcement capacity within the scope of the action plan: high-frequency remote sensing-based monitoring of recent forest clearing activity. Developed by Brazil's National Institute for Space Research (Inpe), the System for Real-Time Detection of Deforestation (DETER) is a satellitebased system used to locate recent deforestation hot spots. DETER uses satellite imagery to regularly scan the full extent of the Brazilian Amazon, looking for changes in land cover. Upon detection, forest disturbances map onto georeferenced alerts signaling areas in need of attention. Inpe forwards these alerts to the Brazilian Institute for the Environment and Renewable Natural Resources (Ibama), which operates as the national environmental police and law enforcement authority. Ibama then uses these alerts to target Amazon law enforcement activities.

When adopted in 2004, DETER produced biweekly maps of deforestation alerts. Since 2011, Inpe processes satellite imagery on a daily basis, providing Ibama with updated information on recent forest clearing activity every weekday. Prior to the implementation of DETER, intelligence regarding recent deforestation hot spots largely depended on voluntary and anonymous reports of threatened areas, seldom allowing law enforcers to locate and reach these spots in a timely manner. In Brazil's institutional setup, timing is fundamental. Law enforcers can more easily punish offenders for illegal forest clearings when catching them red-handed, as offenders can thereby be held directly accountable for the crime. ${ }^{6}$ DETER therefore represented a major improvement in Amazon environmental enforcement capacity, allowing authorities to better identify, more closely monitor, and more quickly act upon areas being illegally cleared. Throughout the first decade of the PPCDAm, the system served as the main tool for targeting

\footnotetext{
${ }^{6}$ Brazilian environmental legislation allows for punishment of past deforestation, but effective sanctioning of past clearings in the Amazon, where land and production property rights are knowingly unclear (Mueller et al., 1994; Alston et al., 2000), is far less feasible.
} 
Amazon enforcement efforts and thereby became the cornerstone of tropical deforestation monitoring and law enforcement.

The main challenge in empirically assessing the impact of law enforcement on Amazon forest clearings is to adequately address endogeneity between police presence and illegal activity. Hargrave and Kis-Katos (2013) offer a first attempt at estimating enforcement effectiveness using panel data at the municipality level. The authors use a state-level measure of environmental fine intensity to instrument for the municipal intensity of law enforcement, and further test whether effects hold in a generalized method of moments estimation framework. Results indicate that municipalities with more intense law enforcement saw a significant reduction in deforestation. Using satellite cloud cover as an arguably more exogenous instrument for the local presence of law enforcers, Assunção et al. (2017b) corroborate this finding for the post-DETER period. They estimate that, from 2006 through 2011, monitoring and law enforcement helped avoid an average of about 2.2 million hectares of Amazon forest clearings per year, making it the policy effort that most contributed to the observed post-PPCDAm deforestation slowdown. In an analysis restricted to the 2009 through 2011 time period, Börner et al. (2015) recover heterogeneous impacts for law enforcement. The authors assess sub-municipal effects of enforcement using spatially explicit data on field inspections and matching to address endogeneity. They conclude that enforcement curbed large-scale clearings, but was ineffective in containing small ones. Combined, these results indicate that monitoring and law enforcement were effective in combating Amazon deforestation within the scope of the action plan.

\subsection{2}

\section{Priority Municipalities}

The creation of the priority municipalities list was one of the most innovative policies proposed by the PPCDAm. In late 2007, Brazil established the legal basis for singling out municipalities with intense recent deforestation activity and taking differentiated action towards them (Brasil, 2007). These municipalities are classified as in need of priority action to prevent, monitor, and combat deforestation — in practice, they are blacklisted. Differential action taken in priority municipalities largely consists of more rigorous environmental monitoring and law enforcement. In addition to concentrating a large share of Ibama's attention and monitoring efforts, priority municipalities anecdotally became subject to a series of additional non-policy penalties, including economic sanctions applied by commodity 
supply chains and compromised political reputations for mayors. An updated list of municipalities has been announced annually since 2008. Exiting the list is conditioned upon significantly reducing deforestation. As of mid-2018, a total of fifty-two Amazon municipalities have received priority status, and only eleven of these have been unlisted.

Among PPCDAm policies, priority municipality listing appears to have received most attention in the evaluation literature. Arima et al. (2014) provide one of the earliest assessments of the policy's direct impact. Using municipality-level matching and a difference-in-differences design, the authors estimate that priority municipalities saw a significant reduction in forest clearings. This finding is corroborated by Assunção and Rocha (2014) in a panel analysis that controls for municipal fixed effects. To explore potential mechanisms through which priority status led to falling deforestation, the authors test whether the policy influenced agricultural production, credit concessions, and environmental fines. Results indicate that only fines were significantly affected by priority status and that, when adequately controlling for law enforcement, the priority municipalities policy had no significant impact on deforestation. This, the authors argue, suggests that the policy's effect can be fully explained by stricter monitoring and law enforcement. Cisneros et al. (2015) challenge this conclusion based on results from municipality-level matching and net average treatment analysis. They, too, find that priority status had a negative impact on deforestation, but estimate a relatively small contribution from environmental fines. The authors interpret this as evidence that non-enforcement mechanisms, such as jeopardized political reputation and supply chain penalties, account for the impact of priority municipalities. Abman (2015) further supports the role played by reputational risk with evidence that, after the adoption of the priority municipalities policy, voters punished local politicians. By exploring binding term limits, the author shows that deforestation did not differ across municipalities with mayors eligible versus ineligible for reelection prior to the existence of the priority list. After 2008, however, forest clearings saw a greater decline in municipalities where mayors could be reelected, and voters penalized incumbent candidates at the ballot at a higher rate in priority municipalities.

Beyond measuring direct effectiveness, the literature has also investigated potential policy spillovers. Although Cisneros et al. (2015) find no significant impact of priority status on neighboring municipalities, Andrade (2016) documents a significant and economically large reduction in forest clearings in non-priority municipalities around priority ones. Using a spatial difference-in-differences estimator, the author shows that this 
deterrent spillover effect decreases as the distance to the priority municipality increases. Assunção et al. (2018b) also explore spillovers, but within a context of optimal policy design. To allow for heterogeneous treatment effects in this optimization framework, the authors estimate both direct and spillover effects of the priority municipality policy via a changes-in-changes model. Again, results indicate a strong causal reduction in deforestation in priority municipalities, as well as a significant (but smaller) influence on non-priority ones. Finally, Koch et al. (2018) address spillovers from a different perspective, focusing on the policy's impact on agricultural production. Although the negative effect of priority status on forest clearings remains significant, neither matching difference-in-differences nor synthetic control estimators point to a decrease in agricultural measures. This suggests that priority municipalities did not face a trade-off between agricultural production and forest conservation.

\section{2 .3}

\section{Conditional Rural Credit}

In an attempt to restrict financial resources to agricultural producers who did not abide by conservation policy, the Brazilian Central Bank conditioned the concession of rural credit for agricultural activities in the Amazon upon proof of borrowers' compliance with legal titling procedures and environmental regulation (Brasil, 2008b). The condition applied to all activities in rural establishments inside the Amazon biome as of mid-2008, and was compulsory across public banks, private banks, and credit cooperatives. Requirements included property registration in federal registries and state-issued documentation attesting the rural establishment's environmental regularity. Exemptions were immediately granted to small-scale producers and, over time, were extended to additional groups of allegedly vulnerable borrowers. Following its adoption, the policy was subject to a series of qualifications that eased conditions for credit concession targeting specific groups, who were henceforth allowed to present self-declaratory environmental documentation instead of state-issued ones.

Restricting financial resources does not unambiguously favor forest conservation (Angelsen and Kaimowitz, 1999). If resources are used to promote clearings, deforestation might decrease in response to the restriction. However, if resources fund land-sparing agricultural practices or provide borrowers with an alternative to clearing forest, a policy that reduces the availability of these resources might contribute to increased deforestation. Which of these mechanisms prevails in practice is a matter of empirical 
investigation. To the best of my knowledge, the only study to directly measure the impact of the 2008 Amazon credit policy is that of Assunção et al. (2018a). The authors explore the policy's inherent discontinuity along the biome border to create arguably comparable treatment and control groups composed of municipalities within a set distance on either side of this border. Using exclusive panel contract-level data and difference-in-differences methodology, they find a significant post-policy reduction in the concession of rural credit inside the Amazon biome. Estimated effects are only significant for large- and medium-sized loans, which is consistent with the exemptions granted to small-scale producers. Moreover, Assunção et al. (2018a) argue that the policy-induced restriction serves as an exogenous source of variation in credit and, using it as an instrument for credit concession, show that the policy helped contain deforestation. Its impact is particularly relevant in municipalities where cattle ranching is the leading economic activity, indicating that rural credit in these municipalities had been used in forest clearing activities.

\subsection{4}

\section{Protected Territory}

Brazilian protected territory consists of protected areas and indigenous lands. ${ }^{7}$ Forest clearing inside these areas is typically strictly prohibited, though some deforestation may be permitted if duly licensed and/or associated with native people's traditional way of life. The PPCDAm promoted the expansion of protection, which covered about $38 \%$ of Amazon biome territory in 2004, and more than $50 \%$ six years later. Yet, the novelty in the action plan's protected territory policy was not in extending protection, but in targeting it with the explicit goal of containing deforestation pressures. Before the plan, although protected territory spread throughout the Amazon, much of it was located in remote hinterland, far from actual forest clearing threats (DeFries et al., 2005; Joppa et al., 2008; Joppa and Pfaff, 2011). In contrast, under the PPCDAm, protection was allocated based not only on biological and ecological factors, but also on strategic ones - these areas were to serve as shields that stood in the way of advancing deforestation.

The literature documents mixed results regarding protection impacts. Part of it, although recent, focuses on protection assigned prior to the action plan. These analyses often use matching to build a comparable control group for protected territories, and find that protection effectiveness varies across the Amazon landscape, typically with proximity to deforestation pressures

\footnotetext{
${ }^{7}$ See Section 2.2.3 for a detailed explanation of Amazon protected territory policy.
} 
like cities and roads (Pfaff et al., 2014, 2015b). The relationship between protection and regional development is further explored by Herrera (2015). After documenting reduced deforestation in the immediate vicinities of protected territory, the author proposes and empirically investigates potential mechanisms through which these local spillovers might depend on local development dynamics. Findings point towards increased outmigration from and decreased infrastructure development in regions under more extensive protection.

In one of the first assessments of PPCDAms-specific protection, Soares-Filho et al. (2010) model deforestation trajectories and find that forest clearings inhibited by protection accounted for large share of the observed reduction in deforestation through 2006. Nolte et al. (2013) also look at the action plan's earliest phase. They use matching techniques to estimate impacts on deforestation through 2010, distinguishing across protection types and assignment periods. Results indicate that indigenous lands were systematically effective in containing forest clearings, but that strictly protected areas created in the first half of the 2000s were more effective than their sustainable use counterparts. The authors suggest this might have been driven by the creation of a few strictly protected areas in particularly high-pressure areas. These effects contrast with those estimated by Anderson et al. (2016), who apply a spatial regression discontinuity technique to evaluate protected territory created from 2004 through 2010. Their analysis finds no significant impact of protection on forest clearing. Although there is less deforestation in protected versus unprotected territories, the authors argue these differences were already in place before the assignment of protection. Again, this suggests that protection is often granted in areas that are intrinsically subject to less deforestation pressure. Anderson et al. (2016) corroborate this interpretation by presenting null difference-in-differences estimates, alongside empirical evidence that protection is assigned to areas with comparatively low agricultural profitability.

\section{2 .5}

\section{Environmental Registry}

The Rural Environmental Registry (CAR) is a public, electronic, and (once completed) universal registry of rural properties throughout Brazil. It aims at integrating key administrative and environmental data about each property in a single platform for use in monitoring and law enforcement efforts, territorial management, and environmental and economic planning. In addition to administrative data on landholders and land titling documentation, 
registered properties must also inform georeferenced boundaries for property limits and within-property areas of native vegetation. The latter include Legal Reserves and Areas of Permanent Protection, both of which are legal obligations of private landholders as per the Brazilian Forest Code (Brasil, 2012). Registration starts with self-reported data, granting landholders a temporary CAR. State-level authorities are then responsible for verifying compliance with environmental regulation, typically by cross-checking these data against relevant documentation, other existing databases, and satellite imagery; landholders only receive a permanent CAR after due verification.

The CAR is currently a centralized federal system, but it draws on previously existing state systems that date back to the mid-2000s. ${ }^{8}$ With the passing of the new Brazilian Forest Code in 2012, registration in the federal CAR system became compulsory for all rural properties in the country. Landholders were originally given until mid-2015 to complete registration; this deadline has been repeatedly postponed and is now set for late 2018.

Originally conceived as an instrument for environmental regularization of rural properties, the CAR also serves to promote tenure security. Property rights insecurity is a serious problem throughout Brazil, but it is particularly salient in the Amazon. The region is marked by a long history of irregular occupations, land grabbing, and squatting, all of which appear to foster tenurerelated rural conflict (Mueller et al., 1994; Alston et al., 2000; Pacheco, 2009; Chiavari et al., 2016; Fetzer and Marden, 2017). Although the CAR as a policy tool is not unique to the PPCDAm, its development has been so intertwined with the fight against deforestation in the Amazon that I consider it a policy effort within the scope of the action plan.

Empirical assessments of property registration on deforestation practices must tackle selection bias, as properties that registered early are likely intrinsically different to those that either registered later or remain unregistered. As such, most analyses to date are only descriptive (Richards and VanWey, 2016; Assunção et al., 2017a). Two recent attempts to document causal effects of registration are provided by L'Roe et al. (2016) and Alix-Garcia et al. (2017). For Pará state, L'Roe et al. (2016) find no significant impact of CAR registration on forest clearing inside properties, but note that their empirical strategy, which includes property-level fixed effects, is not fit to capture aggregate program impacts. Additionally, they argue that the null effect might be expected in the early registry phase, as the state's use of CAR data during their sample period was largely oriented

\footnotetext{
${ }^{8}$ Some states still run state-level systems that feed into the federal system, while others have no intermediary system of their own. Requirements at the federal level are homogeneous across states.
} 
towards data collection for future monitoring and enforcement efforts. In contrast, looking at Pará and the Amazon biome portion of Mato Grosso state, Alix-Garcia et al. (2017) find that CAR registration significantly reduced deforestation. They restrict their analysis to forested areas that eventually enrolled properties in the CAR, but explore variation in the timing of registration to estimate impacts.

\subsection{6}

\section{Other Contributions}

Since its inauguration, the PPCDAm became an overarching backdrop for Amazon conservation action. Yet, not all efforts to combat tropical forest clearings during the (still ongoing) action plan period were actual components of the federal policy. This section surveys empirical assessments of such efforts, but is restricted to those that look at Amazon deforestation outcomes in the post-plan period.

One of the most high-profile local initiatives was implemented by Paragominas, a municipality in Pará state included in the first priority municipalities listing. In the same year it was blacklisted, Paragominas launched the Green Municipalities Program (PMV) to orchestrate local stakeholders in an effort to reduce deforestation. Two years later, it was the first municipality to be removed from the list. Sills et al. (2015) estimate the impact of PMV conditional on having been blacklisted using a synthetic control method to separate the effect of local governance efforts from those of being targeted as a priority municipality. They provide empirical evidence that PMV reduced deforestation, but only starting in 2012. This lag, the authors argue, is consistent with the finding in Assunção and Rocha (2014) that stricter monitoring and law enforcement were the main drivers of the priority municipality policy impact, leaving little room for other effects. Today, under coordination of the State Secretariat for the Environment, the PMV has extended over more than 100 municipalities in Pará.

Although payment for environmental services schemes (PES) have been widely used in conservation policy throughout the world, they are relatively new in the Brazilian Amazon. ${ }^{9}$ Amazonas state implemented one such scheme in 2007 with the Forest Transfer (BF) program. Payments are made to families living inside protected areas for sustainable use conditional upon compliance with stricter conservation requirements than would typically apply within the protected area. Cisneros (2017) provides one of the first

\footnotetext{
${ }^{9}$ Examples of PES in other countries include Mexico (Alix-Garcia et al., 2013), Costa
} Rica (Robalino et al., 2015), and Uganda (Jayachandran et al., 2017). 
assessments of BF, using spatial matching to test for the program's impact on forest loss, degradation, and fires. The author does not find a significant average conservation effect for $\mathrm{BF}$, but notes that significance varies across combinations of deforestation pressures inside and outside protected areas.

While the post-PPCDAm deforestation slowdown helped draw the attention of the impact evaluation literature to tropical conservation policy effectiveness, several studies that look at deforestation outcomes during this period focus on non-policy contributions. Commodity markets present themselves as key influences on Amazon forest clearing. Hargrave and Kis-Katos (2013) and Assunção et al. (2015) show that, even when accounting for PPCDAm policy impacts, agricultural and timber prices significantly affect deforestation. While logging of high-value timber has been associated with deforestation in the Brazilian Amazon (Chimelli and Soares, 2017), cleared areas are largely used for agricultural production, specifically pasture - from 2004 through 2014, pasture covered about $70 \%$ of deforested area, and cropland only 5\% (Inpe and Embrapa, 2016a). In light of this, the role of prices as determinants of deforestation is an intuitive result, as commodity prices directly affect the expected profitability of expanding production over previously forested areas. Despite being relatively small in comparison to pasture, cropland can be regionally relevant, and the interaction between commodity prices can affect land use. Exploring exogenous variation in crop-to-beef prices, Bragança (2018) finds that a relative increase in crop prices promotes an expansion in farmland for soybean production alongside reductions in cattle ranching and deforestation. The author interprets this pasture-to-cropland conversion as evidence that land use changes that are input-intensive from an agricultural perspective can have local environmental externalities.

Supply-chain conservation initiatives have also sparked much debate. ${ }^{10}$ Two such initiatives stand out in the Amazon. First, the 2006 soy moratorium, which formalized a zero-deforestation agreement for soybean production among retailers, traders, and the civil society. Compliance with the agreement, which is still in place, has been monitored via satellite imagery since 2009. The moratorium is often lauded as one of the main conservation efforts of the 2000s, but the empirical evidence on its effectiveness remains only descriptive. Although the literature documents that direct clearing for soybean production declined following the moratorium, causality has not been established, and there is still uncertainty regarding both indirect impacts inside the Amazon and potential leakage into other soy-producing biomes (Rudorff et al., 2011;

\footnotetext{
${ }^{10}$ See Lambin et al. (2018) for an overview of supply-chain conservation initiatives.
} 
Macedo et al., 2012; Gibbs et al., 2015; Gollnow et al., 2018). Second, legal- and zero-deforestation agreements also exist for Amazon meatpacking companies, but their impacts are only starting to be analyzed. Alix-Garcia and Gibbs (2017) combine property-level data from CAR and acquisitions of Amazon slaughterhouses bought by signatories of these agreements to quantify their effect. They estimate a null average impact on forest cover by 2014, but find that the agreements had a significant reduction in deforestation in properties that registered early in the CAR. The authors conclude that leakage and strategic responses from producers and companies might undermine avoided deforestation from the agreements.

Finally, a growing number of studies is starting to look at forest clearings as a means for local politicians to extract rents. ${ }^{11}$ Cisneros et al. (2013) explore randomized public fiscal audits unrelated to deforestation outcomes to test the association between corruption and forest clearing. Results suggest that, after learning that audits do not target deforestation, corrupt politicians shift their rent-seeking activities towards segments that are less likely to be detected in these audits and thereby contribute to increased clearings. Pailler (2018) corroborates these findings with empirical evidence that municipalities with corrupt mayors running for reelection see more deforestation in election years than those where mayors are not eligible for reelection.

\section{3}

\section{Policy and Academic Challenges}

Today, the PPCDAm is widely regarded as having successfully met its goal of combating Amazon deforestation. The evaluation literature supports this view, providing ample empirical evidence for the effectiveness of Brazil's conservation policy efforts within the scope of the PPCDAm. Yet, important hurdles stand in the path of further reductions in Amazon deforestation and sustainable practices.

From a policy perspective, the action plan must tackle known limitations in both technological and institutional spheres. Brazil's DETER-based tropical monitoring technology, although regarded as the most advanced in the world (Tyukavina et al., 2017), cannot detect deforested areas smaller than 25 ha, due to the spatial resolution in the satellite imagery it uses. In the early 2000s, less than a quarter of total forest area lost per year was cut down in these small patches; ten year later, more than half of annually deforested area occurred in small increments (Inpe, 2017). Several studies document this

\footnotetext{
${ }^{11}$ Burgess et al. (2012) provide one of the first systematized empirical assessments of the political economy of tropical deforestation, but in the context of Indonesia.
} 
change in forest clearing composition, and some suggest it might have been a strategic response of potential offenders seeking to evade monitoring and law enforcement (Rosa et al., 2012; Godar et al., 2012, 2014; Assunção et al., 2017a). In acknowledgment of this, Inpe launched DETER-B in the mid-2010s. The new system also serves to issue alerts for recent forest clearings, but it detects changes in land cover in patches larger than 1 ha, albeit at lower temporal frequency (Diniz et al., 2015). While this is a welcome improvement, overcoming existing institutional barriers is also a challenge in the continuing fight against illegal Amazon deforestation. Enforcement capacity, although substantially enhanced within the PPCDAm, is still hindered by very low fine collection rates, long legal procedures, high execution costs, and insufficient financial and human resources (Börner et al., 2014, 2015; Schmitt, 2015). Furthermore, new empirical evidence should be incorporated into the design of future policy actions. Efforts that were once effective in reducing aggregate deforestation across the Amazon now need to be tailored to regional and local needs to best target location-specific goals (Godar et al., 2014; Richards and VanWey, 2016; Assunção et al., 2017a), and forest degradation, which has become increasingly relevant as compared to clear-cut deforestation, must be directly accounted for and combated (Souza Jr. et al., 2013; Rappaport et al., 2018).

From an academic perspective, policy design could greatly benefit from research that directly addresses spatial dynamics of land use phenomena and associated socioeconomic processes. Empirical evidence has shown that ignoring this spatial dimension can severely influence estimation results, introducing bias (Nelson and Chomitz, 2011; Robalino and Pfaff, 2012; Pfaff et al., 2015a; Miranda et al., 2016) and limiting the understanding of underlying causal mechanisms for policy impact (Herrera, 2015; Pellegrina, 2015). Moreover, until recently, computational capacity was an important limiting factor for empirical analysis, restricting researchers to the use of aggregate units of observation that often concealed relevant sub-unit spatial dynamics (Avelino et al., 2016; Donaldson and Storeygard, 2016). With recent improvements in data processing power and the increasing availability of high-resolution georeferenced data, a growing number of scholars now highlight the need to take a closer look at spatially explicit deforestation processes at the sub-municipal level (Avelino et al., 2016; Busch and Ferretti-Gallon, 2017; Pfaff and Robalino, 2017).

Furthermore, in a recent review of the conservation program effectiveness literature, Pfaff and Robalino (2017) document that evaluation efforts are largely focused on estimating only direct impacts. As most of the PPCDAm- 
related literature surveyed in this chapter falls into this category, little is currently known about the action plan's indirect impacts. ${ }^{12}$ Baylis et al. (2016) argue that indirect impacts are part of the actual treatment effect and should therefore be incorporated into empirical evaluations. Existing research provides useful examples of what can be learned from these impacts, including, but not limited to: how the interaction between overlapping policies can either enhance or limit individual policy impacts (Robalino et al., 2015; Sims and Alix-Garcia, 2017); how conservation spillovers vary across the landscape and how this can be used to shed light on underlying policy mechanisms (Robalino et al., 2017); and how optimal policy design and allocation are influenced by spillovers and complementarities across policies (Assunção et al., 2018b). Finally, accounting for externalities is key for cost-effectiveness analysis, which, in turn, is a valuable tool for policymaking. ${ }^{13}$

Efforts that address these research gaps could contribute to inform policymakers and thereby improve policy design. The remaining chapters aim at taking a step in this direction by exploring direct and indirect impacts of action plan policies using a georeferenced ten-year panel dataset to account for spatial dynamics.

\footnotetext{
${ }^{12}$ Evaluations of the priority municipalities policy are a notable exception to the extent that many consider policy spillovers, though typically at the municipality level.

${ }^{13}$ Souza-Rodrigues (2018) provides an example of one such policy- and cost-effectiveness assessment framework, demonstrating how it could be used to inform policy.
} 


\section{Chapter 2 \\ The Deforestation Menace}

\section{1 \\ Introduction}

Territorial protection is one of the leading conservation policies worldwide (Nolte et al., 2013; Pfaff and Robalino, 2017). It has long been used in the Brazilian Amazon, well before the onset of the PPCDAm. By 2004, nearly two fifths of Amazon biome territory were already under protection. Yet, the action plan introduced a novel siting strategy for protection. Henceforth, although biological and ecological factors remained important allocation criteria, current and future deforestation risks were to be taken into account when granting protection. In addition to their original goals of conserving biodiversity and protecting natural habitats, Amazon protected territories in high-risk zones were also meant to serve as shields against advancing forest clearings.

In theory, protection's shielding capacity stems from its ability to deter environmental offenders. Amazon protected territory is under greater scrutiny and monitoring attention, which increases an offender's chance of getting caught. Moreover, Brazil's regulatory framework allows for harsher punishment of environmental infractions committed within protected territory. As such, because there is a higher cost of clearing protected versus unprotected forest, legal protection could grant actual protection against deforestation to the extent that offenders refrain from acting within protected territory. However, shielding is only effective if the forest under protection faces an actual threat of deforestation - areas that are not under forest clearing pressure are unlikely to see deforestation with or without protection. This is one of the main challenges in evaluating protection effectiveness, since protected territory is often located in remote areas (DeFries et al., 2005; Joppa et al., 2008; Joppa and Pfaff, 2011). In light of this, the empirical setting of the post-PPCDAm Brazilian Amazon, in which protection was intentionally allocated in high-risk areas, offers a unique opportunity to assess protection effectiveness against deforestation.

This chapter uses a spatially explicit panel dataset to empirically test the shielding capacity of protected territory. It starts by establishing a means of capturing areas under greater deforestation pressure. The satellite-based 
monitoring system adopted under the PPCDAm issued alerts for recent changes in forest cover, such that regions with greater alert intensity typically held more intense clearing activity. As forest clearings exhibit spatial persistence, it seems reasonable to posit that areas close to deforestation are under greater threat of being themselves deforested. Drawing on the dataset's raster structure to mitigate concerns of potentially confounding unobservables via the use of cell fixed effects, the analysis shows that this relationship indeed holds in the data. For a given cell and year, greater alert intensity within $50 \mathrm{~km}$ of the cell is associated with increased forest clearings inside the cell the following year. Thus, neighborhood alert intensities serve as a measure of local deforestation risk.

The empirical strategy then builds on this measure of exposure to compare forest clearing outcomes in unprotected and protected territory under equivalent deforestation pressures. Results document protection's efficacy in a high-risk context, with significantly less forest being cleared in protected cells than in unprotected ones. Estimates indicate that, under an increase of one standard deviation in the intensity of neighborhood alerts, the difference in clearings for unprotected and protected cells amounts to $3 \%$ of the sample standard deviation, or $26 \%$ of the sample mean. Findings therefore corroborate protected territories' effectiveness in shielding vegetation within their domain from deforestation activity.

To shed light on the economic significance of this effect, observed aggregate forest clearing trends are compared to counterfactual ones in which protection has been revoked. Annual deforestation trends for cells that lose protection in the hypothetical scenarios are significantly affected. Particularly in high-pressure periods, protected cells saw less forest clearings than if they had not been granted legal protection. This pattern holds across protection types, but is weaker for indigenous lands than for protected areas. Yet, counterfactual exercises that estimate deforestation outcomes across both protected and unprotected cells reveal that aggregate deforested area does not change when protection is revoked. Protected territory therefore seems to affect spatial forest clearing dynamics, but not the overall level of deforestation. I interpret this as evidence that, although protected territories effectively shield forests under their domain, they essentially deflect deforestation to unprotected regions.

This chapter is closely related to the literature that assesses the effectiveness of protected territory. Being one of the most widely used conservation policies in the world, protection has long been the subject of empirical impact evaluation. Cross-country assessments typically find that 
protected areas see less deforestation than unprotected ones, but highlight that protection is often located in remote areas that are not subject to high deforestation pressures (DeFries et al., 2005; Joppa and Pfaff, 2011; Nelson and Chomitz, 2011; Abman, 2018). Similar results are found in country-specific analyses, many of which try to account for varying forest clearing pressures to mitigate bias when estimating protection impact. Examples include studies for protected territory in Chile (Arriagada et al., 2016), Costa Rica (Andam et al., 2008; Pfaff et al., 2009), Indonesia (Gaveau et al., 2012; Shah and Baylis, 2015), Mexico (Honey-Rosés et al., 2011), Peru (Miranda et al., 2016), and Thailand (Sims, 2010, 2014).

Several works have looked specifically at protection in the Brazilian Amazon, albeit not necessarily within the scope of the PPCDAm. Protection is typically shown to work as a means of conserving forest cover, though authors have found relevant variations in effectiveness across time and space (Nepstad et al., 2006; Nolte et al., 2013; Pfaff et al., 2014, 2015b). Anderson et al. (2016) is an exception to the extent that it finds no significant impact of protection on forest preservation in the Amazon. The authors speculate that this null average effect might result from protection being assigned mostly to remote areas that are not under significant deforestation pressure. This study advances the literature on protection effectiveness by proposing an empirical approach that focuses on assessing protected territory's shielding capacity specifically in areas that face actual threats of suffering forest loss.

The chapter proceeds as follows: Section 2.2 describes the institutional context for environmental monitoring and protection in the Amazon; Section 2.3 details the empirical strategy; Section 2.4 presents dataset and variable construction procedures; Section 2.5 reports and discusses estimation results and counterfactual simulations; and Section 2.6 concludes with policy implications.

\section{2}

\section{Institutional Context}

This section provides background information on the legality of Amazon deforestation, the satellite-based monitoring system, and protected territory policy. It closes with a discussion on how this institutional context might influence a potential offender's land use decision-making process. 


\subsection{1}

\section{Amazon Deforestation as an Illegal Activity}

Brazil's 1988 Federal Constitution determined that offenders who engage in actions that are harmful to the environment can be held thrice responsible, being subject to legal penalties in civil, administrative, and criminal spheres (Brasil, 1988). These penalties need not be mutually exclusive and accumulate across spheres. The illegal clearing of native vegetation is thus punishable by law.

Regulations setting the legality of forest clearing in the Amazon vary across private and public lands. Inside private properties, deforestation is only legal if the clearing of a specific area has been duly authorized or licensed by subnational (usually state-level) environmental authorities. Landholders must also comply with the Brazilian Forest Code, which sets legal guidelines for land cover conversion and protection of native vegetation inside private properties. ${ }^{1}$ For properties inside the Amazon biome, the Forest Code is particularly restrictive. It requires landholders to preserve at least $80 \%$ of their property as native vegetation, and determines areas of permanent protection, such as riparian forests, which cannot be cleared in any circumstance (Brasil, 2012). Public lands in the Amazon are largely composed of protected territory or undesignated lands. In the former, forest clearing is either fully prohibited or is permitted only under strict licensing; in the latter, it is always prohibited.

Existing data on Amazon deforestation do not allow legal clearings to be distinguished from illegal ones. There is compelling, albeit only anecdotal or localized, evidence that the vast majority of areas deforested since the launch of the PPCDAm were cleared under illegal circumstances. The Brazilian Amazon biome extends over more than 420 million hectares. By 2014, protected territory, where forest clearing practices are mostly illegal, covered nearly half of this area. The remaining unprotected territory is a combination of as-of-yet undesignated public lands and private properties. Clearing in the former is also illegal. Recent estimates for the extent of private property in the Amazon biome set total private land area at approximately 180 million hectares (SFB, 2017). While clearings inside these properties could be legal if both duly authorized/licensed and in accordance with Forest Code requirements, property-level assessments indicate compliance with the Forest Code in the Amazon is generally very poor (Michalski et al., 2010; Godar et al., 2012; Börner et al., 2014). Because forest clearings in non-compliant properties are carried out in irregular circumstances from an environmental legislation standpoint, they are deemed illegal. In light of this, although some deforested

\footnotetext{
${ }^{1}$ See Chiavari and Lopes (2015) for an explanation of the Brazilian Forest Code.
} 
areas captured in this analysis may refer to legal clearings, I assume that they represent only a small fraction of total sample deforestation. ${ }^{2}$ Hence, forest clearings detected by the monitoring system most likely capture illegal activity punishable by law.

\subsection{2}

\section{Monitoring and Law Enforcement}

Since its implementation in the mid-2000s, DETER has served as the main tool for targeting law enforcement efforts in the Amazon. The system regularly scans the full extent of the Brazilian Amazon for signs of tropical degradation or deforestation, which, when detected, generate georeferenced alerts. Law enforcers visit alert locations and, upon finding evidence of illegal clearing activity, charge offenders. Criminal charges are later processed via the public prosecution system, but on-site law enforcement personnel can apply administrative penalties.

Although law enforcement operations need not be exclusively based on DETER alerts, the system is the official cornerstone of Amazon deforestation monitoring (Börner et al., 2015; Schmitt, 2015). In addition to providing fast, frequent, and spatially far-reaching information on recent degradation and deforestation activity, DETER also increased law enforcers' capacity of catching offenders red-handed and, thus, of punishing them. ${ }^{3}$ Anecdotal evidence provided by Ibama personnel support the idea that the new monitoring system effectively captured recent forest clearing hot spots and allowed for more efficient targeting of enforcement operations. It is therefore plausible to argue that areas with greater intensity of DETER deforestation alerts are also areas that are currently undergoing more intense forest clearing activity.

\subsection{3}

\section{Protected Territory}

Brazilian protected territory is composed of protected areas and indigenous lands. Although both categories fall into the larger public lands domain, protected areas and indigenous lands are governed by separate

${ }^{2}$ In informal conversations, law enforcement personnel have suggested that less than $10 \%$ of deforested areas are actually legal. Souza-Rodrigues (2018) reports a similar estimate, also based on informal interactions.

${ }^{3}$ Catching offenders red-handed enhances punishment capacity to the extent that it enables law enforcers to hold someone accountable for the illegal activity. This is particularly relevant in the Amazon's context of unclear and insecure property rights (Mueller et al., 1994; Alston et al., 2000), and for a subset of sanctioning instruments - namely the establishment of embargoes and seizure of machinery, tools, and production goods - whose use essentially depends on law enforcers having access to seizable items and/or offenders' identities. 
Figure 2.1: Extent of Protected Territory, 2004-2014

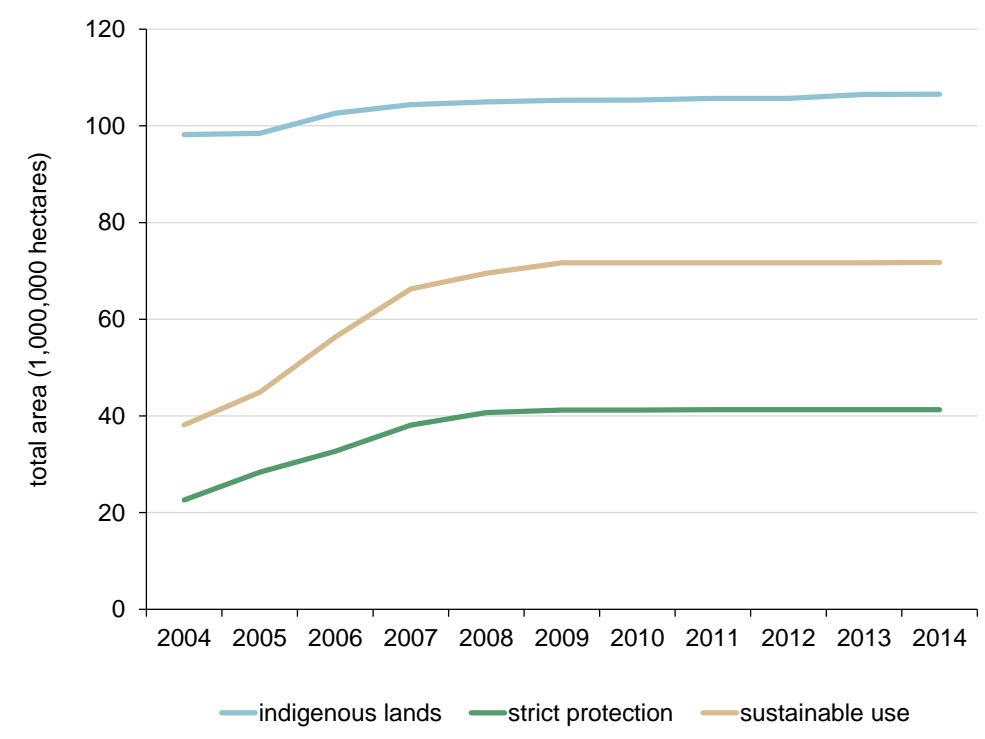

Notes: The graph presents total area under type-specific protection in the Amazon biome. Data sources: FUNAI and ISA (indigenous lands); MMA (protected areas).

authorities and are subject to different regulations. Protected areas can be either strictly protected, where no deforestation of any form is legal, or of sustainable use, where forest clearing may be legal if duly licensed and in accordance with the area's management plan. Deforestation licensing requirements are stricter inside areas of sustainable use than in private properties. Following a period of technical assessment and public consultation, protected areas are created via laws or decrees. They can be managed at federal, state, or municipal levels, but federal and state areas are far more common in the Amazon. In contrast, indigenous lands cannot be created, only recognized. Typically, this means that areas assigned as indigenous lands have traditionally been occupied by indigenous peoples. Full recognition is only granted after the area completes a multi-stage administrative process. The recognition process can be roughly broken into the following stages: assessment, physical demarcation, declaration, presidential ratification, and registry. Clearing of native vegetation in indigenous lands is only legal if performed by indigenous peoples as part of their traditional way of life.

When the PPCDAm was launched in 2004, about 38\% of Amazon biome territory was under protection as protected areas (61 million hectares) or indigenous lands (98 million hectares). Over the next decade, the extent of protected areas nearly doubled to 113 million hectares, and indigenous lands expanded to a total of 107 million hectares (see Figure 2.1). By 2014, more 
than half of the Amazon biome was under protection. In addition to promoting expansion, the action plan also inaugurated a novel siting strategy for protected territory. Through the mid-2000s, protection had been granted based on an area's biological and ecological characteristics, with the intent of conserving biodiversity and protecting natural habitats. While these criteria still played an important role in allocating protection under the PPCDAm, protected territory was henceforth assigned with an additional explicit goal — block advancing deforestation. Current and future deforestation risks were to be taken into account when granting protection, such that protected territories in high-risk zones were meant to serve as shields against forest clearing pressures.

Prior to the PPCDAm, tropical clearings concentrated along the so-called Deforestation Arc, a region that historically captured the agricultural frontier pushing into the forest (see Figure 2.2). Protected territory spread throughout the Amazon, but much of it was located in the Amazon hinterland. ${ }^{4}$ Yet, under the action plan, almost 35 million hectares of protected territory were allocated in regions under high risk of deforestation, as captured by their proximity to the Deforestation Arc (see Figure 2.3). Newly protected territory in these high-pressure zones largely consisted of protected areas for sustainable use and strictly protected areas, which could be more easily created by the government as compared to indigenous lands.

In practice, how is protection implemented? From a legal standpoint, an offender who engages in illegal forest clearing activity in protected territory is subject to harsher criminal and/or administrative penalties. Someone occupying territory in public domain, which includes both protected areas and indigenous lands, can be criminally charged and sentenced to three years of jail time (Brasil, 1966). Because Brazil's Federal Constitution assigned special preservation status to the Amazon biome, illegal deforestation in all public lands inside the biome is already subject to harsher penalties than outside it (Brasil, 1988, 1998). The country's Law of Environmental Crimes reinforces this by determining that illegal deforestation and/or degradation in all public areas of the Amazon biome are punishable with fines and two to four years of imprisonment (Brasil, 1998). Moreover, all direct and indirect harm caused to protected areas are further subject to one to five years of imprisonment (Brasil, 1998). ${ }^{5}$

\footnotetext{
${ }^{4}$ Several studies empirically document that protection in tropical forests, including the Amazon, is often located in remote areas far from deforestation pressures (DeFries et al., 2005; Joppa et al., 2008; Joppa and Pfaff, 2011).

${ }^{5}$ Although protected areas for sustainable use are often mistakenly thought to be laxer in terms of environmental regulation, this view has no legal support; if not duly licensed/authorized, deforestation in these areas is legally equivalent to forest clearing in strictly protected areas.
} 
Figure 2.2: Deforestation and Protection Before the Action Plan

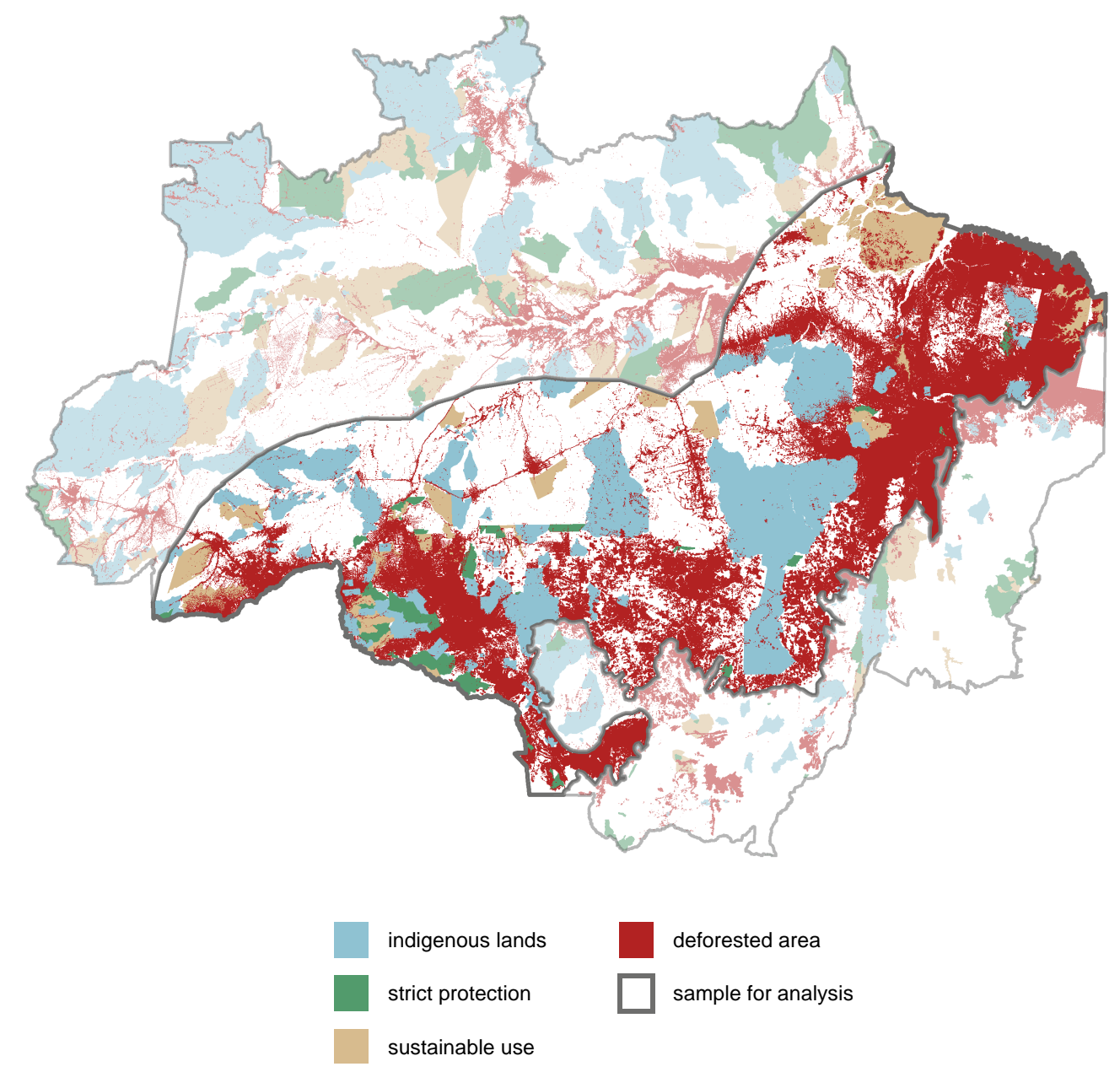

Notes: The map shows accumulated deforestation through 2004 and protected territory status in 2004, before the action plan was launched. Dimmed regions are non-sample areas (see Section 2.4.3 for sample definition). Data sources: PRODES/Inpe (deforestation); FUNAI and ISA (indigenous lands); MMA (protected areas); IBGE (Legal Amazon, Amazon biome).

Alongside criminal penalties, offenders also face administrative penalties. Illegal clearings in all public areas of the Amazon biome are subject to a fine of USD 3,000 per cleared hectare; in protected areas, this fine increases to USD 3,800 per cleared hectare. ${ }^{6}$ Protection status also allows enforcers to apply an additional penalty that doubles the total amount offenders must pay (Brasil, 2008a). In addition to the direct financial cost imposed by fines, criminal and administrative processes also carry large processing fees and legal costs. As such, even in a context of knowingly low collection rates for fines (Barreto et al., 2009; Börner et al., 2014; Schmitt, 2015), criminal and administrative charges carry a large financial burden. Fines are also typically accompanied by administrative measures aimed at further increasing this

${ }^{6}$ US dollar values calculated from Brazilian currency using the exchange rate from the period during which the associated regulations were passed. 
burden. These measures include, but are not limited to, seizure of illegally produced goods, seizure and/or destruction of machinery used for forest clearings, and production embargoes (Brasil, 2008a). Combined, criminal and administrative penalties significantly increase the expected cost of clearing Amazon forest under protection.

Beyond the existing legal framework for more severely punishing illegal deforestation inside protected territory, forest clearings in these areas are also subject to considerably greater public scrutiny. In addition to Ibama, which monitors the full extent of the Amazon, the Chico Mendes Institute for Biodiversity Conservation (ICMBio) and the Brazilian Native Peoples Foundation (FUNAI) also perform monitoring of federal protected areas and indigenous lands, respectively. Deforestation in protected territory also attracts much attention from both national and international medias, as well as from the civil society. Finally, native peoples in indigenous lands are anecdotally known to defend their territory from invasions and predatory use by third parties. Although this sort of dedicated monitoring by government agencies and local stakeholders cannot be directly quantified, it is likely that they, too, contribute to the overall sense that illegal clearings in protected territories are being more closely watched than those in their unprotected counterparts.

\subsection{4 \\ Rationale for Individual Land Use Decision}

Since the seminal work of Becker (1968), an individual's decision to engage in an illegal activity has been modeled as an optimization problem in which the individual compares the expected gain of that activity with the expected cost of getting caught and punished. Bearing this in mind, consider an environmental offender who practices illegal deforestation in a given region that holds both protected and unprotected forests. When deciding where to deforest, the cost-minimizing offender will select the area perceived as less likely to result in his getting caught and punished. Because protected territory is under greater scrutiny, offenders clearing protected forests have a higher chance of getting caught. Moreover, when caught, these offenders face more severe criminal and administrative charges, including heavier financial penalties. It is therefore reasonable to posit that the expected cost of clearing forest in protected territory would be perceived as significantly higher, ultimately inhibiting offenders from operating in these territories. As such, legal protection would grant actual protection, serving as a shield against advancing deforestation. 
Figure 2.3: Targeted Expansion of Protected Territory

(a) 2004

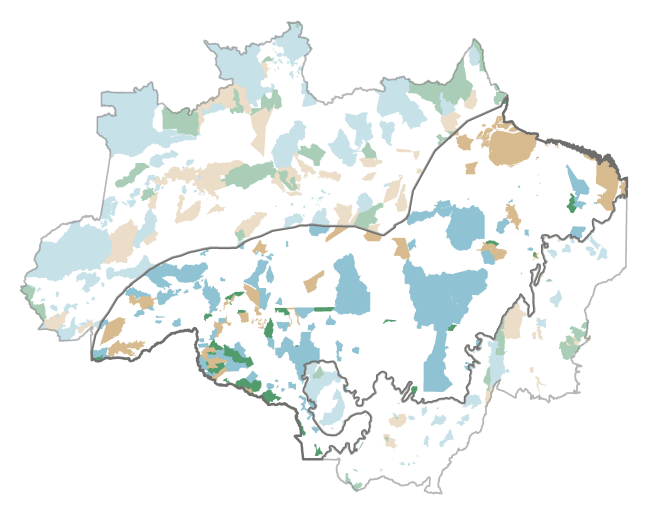

(c) 2008

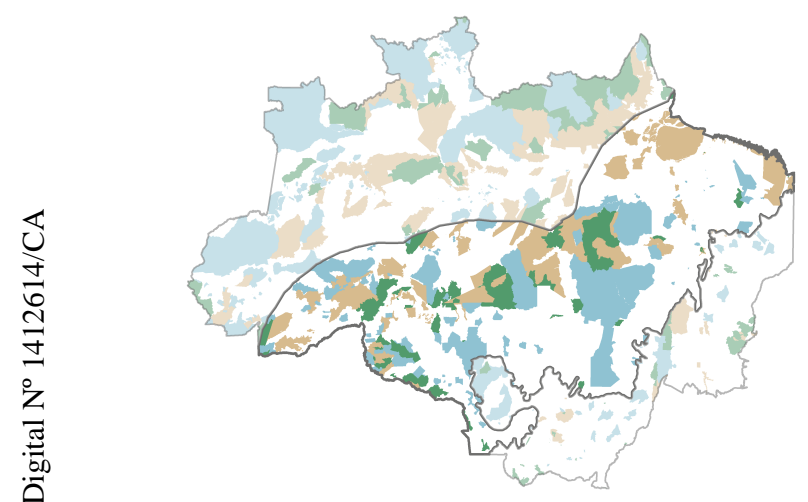

(e) 2012

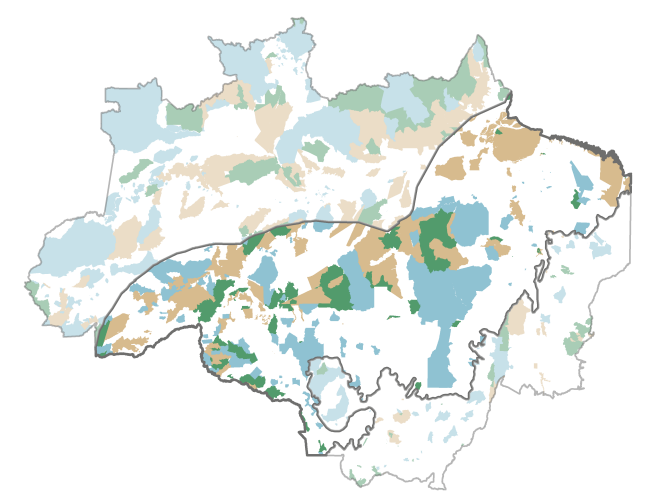

indigenous lands

strict protection (b) 2006

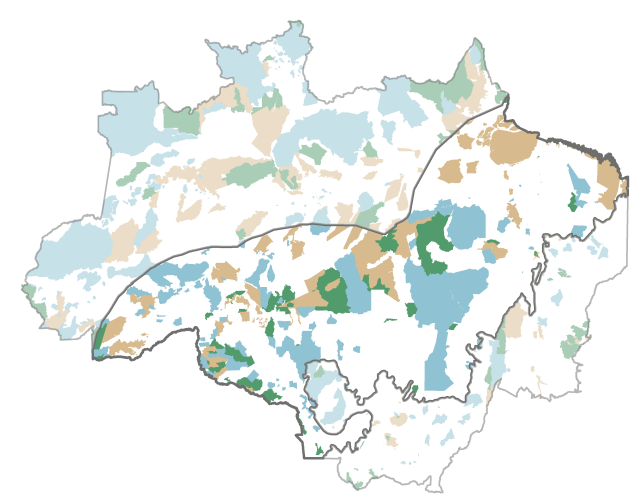

(d) 2010

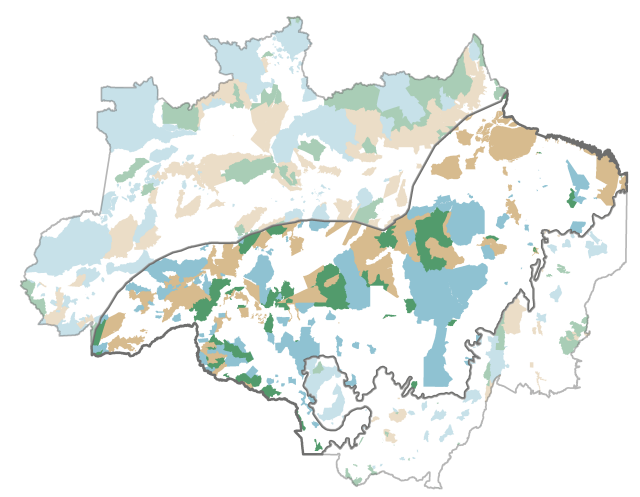

(f) 2014

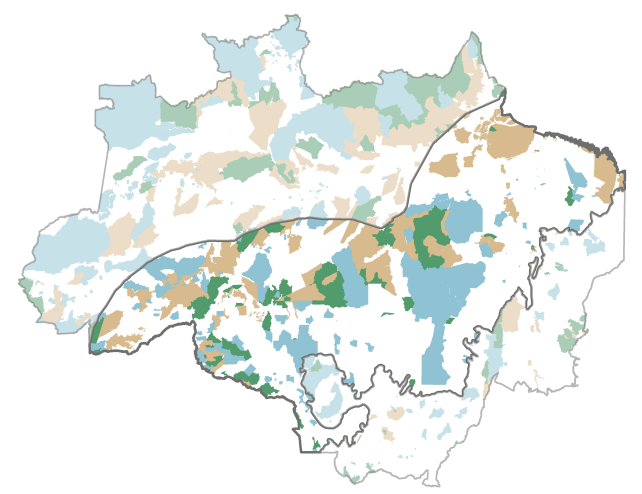

sustainable use

sample for analysis

Notes: The maps show type-specific protection status in select years. Dimmed regions are non-sample areas (see Section 2.4.3 for sample definition). Data sources: FUNAI and ISA (indigenous lands); MMA (protected areas); IBGE (Legal Amazon, Amazon biome). 


\section{3}

\section{Empirical Strategy}

The proposed empirical strategy aims at assessing protected territory's capacity to shield against deforestation by comparing forest clearing outcomes in protected versus unprotected localities under equivalent deforestation pressures. Because deforestation exhibits spatial persistence, areas close to clearing activity are likely under greater risk of being themselves deforested. In light of this, the starting point for the analysis is a test of whether the intensity of alerts in a cell's neighborhood in a given year is associated with forest clearings inside that cell the following year. A positive association indicates that neighborhood alert intensity serves as a measure of cell-level deforestation pressure. The analysis then builds on this using variation in protection status both across cells and over time to evaluate if forest clearings advance over protected versus unprotected cells differently. The benchmark estimation equation is:

$$
\begin{aligned}
\text { deforest }_{i, t}= & \sum_{n \in \partial i}\left\{\alpha_{n} \text { alert }_{n, i, t-1}+\beta_{n}\left(\text { alerts }_{n, i, t-1} * \text { protect }_{i, t-1}\right)\right\} \\
& +X_{i, t-1}^{\prime} \theta+\gamma_{i}+\delta_{t}+\varepsilon_{i, t}
\end{aligned}
$$

where deforest $t_{i, t}$ is the deforested area in cell $i$ and year $t$; for each of cell $i$ 's $n$ neighborhoods, alerts $s_{n, i, t-1}$ is a neighborhood-specific measure of deforestation pressure in year $t-1$, as measured by neighborhood alert intensity; protect $_{i, t-1}$ is an indicator that equals 1 when cell $i$ is protected in year $t-1$, and 0 otherwise; $X_{i, t-1}$ is a vector of cell-level controls for geography (cloudbased satellite visibility, weather) and observed conservation policy (local law enforcement, priority municipality status); $\gamma_{i}$ and $\delta_{t}$ are, respectively, cell and year fixed effects; and $\varepsilon_{i, t}$ is the cell-year idiosyncratic error. Estimates are robust to heteroskedasticity, and standard errors are clustered at the municipality level in all specifications, making them robust to intra-municipal serial correlation (Bertrand et al., 2004). For each cell, multiple neighborhoods are formed by concentric rings of increasing diameter around it. Dataset construction is such that each of the cell's neighborhood rings contains neither the cell itself nor any of the smaller concentric rings (see Appendix A.1). Coefficients $\alpha_{n}$ therefore capture whether forest clearings happening in a cell's neighboring region are associated with the risk of deforestation happening inside the cell; $\alpha_{n}>0$ indicates that cells facing more intense clearing activity in their surroundings are under greater deforestation pressure. In turn, interaction coefficients $\beta_{n}$ capture a differential effect for protected cells; $\beta_{n}<0$ indicates that deforestation was effectively diverted from protected cells. 
The identification of protected territory's shielding capacity fundamentally comes from the comparison of deforestation outcomes in protected versus unprotected cells exposed to equivalent deforestation pressures. This is particularly relevant in light of the discussion in the literature that the variation in deforestation pressures across the landscape have important implications for the evaluation of average protection effectiveness in the Amazon (Nepstad et al., 2006; Nolte et al., 2013; Pfaff et al., 2014, 2015b). The use of cell fixed effects controls for potentially confounding time-invariant cell characteristics, such that coefficients are estimated using within-cell variation across time. Equation 2-1 also includes year fixed effects to recover impacts net of sample-wide annual shocks, as well as a host of cell-level controls to mitigate omitted variable bias. The first set of controls focuses on geographic variables. Remote sensing data are limited by visual obstructions that block the Earth's surface from view in imagery. Satellite visibility can affect not only recorded cell deforestation, but also alerts issued inside the cell (see Appendices B.1.1 and B.1.2). The benchmark specification accounts for these effects using information on unobservable areas in satellite imagery for both forest clearing and alert data. Local weather might also be correlated with local deforestation and neighborhood alert intensity. Certain weather conditions could favor clearings by facilitating access to forested areas, enabling the use of fires, or even influencing the expected productivity and thereby the expected value of deforested land. Rainfall and temperature could also correlate with cloud coverage limiting satellite visibility. All specifications therefore include controls for average annual temperature and total annual rainfall. The second set of controls accounts for other policies aimed at combating deforestation. These are admittedly more endogenous, but serve as a robustness test for the stability of estimated coefficients. Policy controls include the indicator for cell protection status protect $_{i}$, an indicator variable flagging whether the cell belong to a priority municipality, and a measure for the intensity of alerts issued inside the cell.

The timing of the deforestation response is also a relevant component of the identification strategy. When choosing where to deforest, an offender plausibly uses observational data collected in the past to inform his present decision. Moreover, moving across Amazon forest sites, where transport infrastructure is knowingly very poor (Weinhold and Reis, 2008; Börner et al., 2014, 2015), is a time-consuming process. As such, the response in deforestation is not expected to be concurrent, but rather lagged. Equation 2-1 sets a one-year lag for most independent variables, the only 
exception being satellite visibility for deforestation outcome data.

\section{4 \\ Data}

The analysis is entirely based on spatial data that are publicly available from a variety of sources. This section provides a brief description of variables and presents descriptive statistics. The appendices contain detailed information on the empirical spatial setup (Appendix A) and data sources (Appendix B).

\subsection{1 \\ Main Variables}

Cell-level deforestation is built from georeferenced data on Amazon-wide annual deforestation increments from PRODES/Inpe (see Appendix B.1.1). The outcome of interest is deforestation increment as a share of cell area. It is calculated using vector deforestation data rasterized at the $30 \mathrm{~m}$ resolution and total minicell count for each cell.

Forest clearing alert data come from DETER/Inpe (see Appendix B.1.2). Monthly vector data on georeferenced alerts are rasterized at the $900 \mathrm{~m}$ resolution, such that a cell will take on a value of 1 if it contains an alert and a value of 0 otherwise. ${ }^{7,8}$ Neighborhood intensity is calculated as the annual number of alert cells in each neighborhood as a share of total neighborhood cell count. ${ }^{9}$

Spatial data on protection history for strictly protected areas and protected areas for sustainable use are provided by the MMA. Analogous data for indigenous lands are compiled from FUNAI and the non-governmental Socioenvironmental Institute (ISA) (see Appendix B.2). Annual protection status indicators are constructed from type-specific protected territory cover rasterized at the $900 \mathrm{~m}$ resolution, which are then used to build a general protection indicator that annually flags whether a cell was under protection of any kind.

${ }^{7}$ In practice, the rasterization algorithm assigns value 1 to a cell only if its centroid is contained within a polygon in the vector data. Because deforestation alerts can be as small as $25 \mathrm{ha}$ and the raster cells have an area of $81 \mathrm{ha}$, running the algorithm on the raw vector resulted in the loss of a large amount of alerts. I therefore created a $1 \mathrm{~km}$ buffer around all alerts and only then rasterized the alert-plus-buffer vector data, thereby ensuring that if a cell fell within $1 \mathrm{~km}$ of an alert, it would be assigned value 1 during rasterization. For simplicity, I refer to this alert-plus-buffer area simply as the alert area throughout the analysis.

${ }^{8}$ There are a few occurrences of biweekly data, particularly in earlier DETER years. For a month with two deforestation alert datasets, I overlay the biweekly data to calculate total alert area for that month, as per Inpe's recommendation.

${ }^{9}$ Missing months in vector data indicate that no alerts were issued by DETER in that month. 


\subsection{2}

\section{Controls}

The benchmark specification in Equation 2-1 includes two sets of celllevel controls, in addition to cell and year fixed effects. First, geography controls account for natural phenomena. Clouds, shadows cast by clouds, and smoke from forest fires can all affect visibility in satellite imagery. Inpe releases spatial data on land areas blocked from view for both PRODES and DETER. Satellite visibility controls for PRODES indicate the annual share of cell area suffering from visual obstructions, as captured by rasterizing vector data on unobservable areas at the $30 \mathrm{~m}$ resolution. As DETER offers monthly data, its satellite visibility control is a cell-level measure of time spent blocked from view during one year. ${ }^{10}$ Monthly data compiled by Matsuura and Willmott (2015) serve as the basis for building weather controls. The authors use multiple sources of global weather data and apply geographic extrapolations to calculate a regular georeferenced world grid of estimated temperature and rainfall over land. ${ }^{11}$ Data points in the original dataset refer to grid nodes, not cells, such that average annual temperature and total annual rainfall are calculated from the monthly data for each Amazon grid node. Because the spatial resolution for this dataset is much lower than $900 \mathrm{~m}$, cell weather values are based on the average values for all grid node values within $180 \mathrm{~km}$ of each cell to ensure all sample cells had non-missing weather data.

Second, observed policy controls address relevant conservation efforts that could affect deforestation pressures and local clearings. Two of these controls come from dataset that have already been described: the cell indicators for protection status and DETER alert area. The latter is an indicator variable if the cell itself contained a DETER alert in a given year. The last control refers to the cell being in a priority municipality. It is built from information contained in each of the MMA's annual listings of municipalities that were attributed priority status or removed from the blacklist. The 2007 Brazilian municipal division from the Brazilian Institute for Geography and Statistics (IBGE) is rasterized at the $900 \mathrm{~m}$ resolution and is used to assign each cell to a single municipality.

\footnotetext{
${ }^{10}$ As with DETER alerts, there are some months for which Inpe releases biweekly cloud coverage vector data. For these months, I intersect the biweekly data to identify areas that were blocked from view throughout the whole month. Note that this is different to the overlay method used for alerts - the procedure is performed as per Inpe's recommendation.

${ }^{11}$ This database has been extensively used in the economic literature both to evaluate the impact of climate variables on economic outcomes and to provide relevant rainfall and temperature controls (Dell et al., 2014).
} 
Figure 2.4: Amazon Spatial Boundaries and Sample Definition

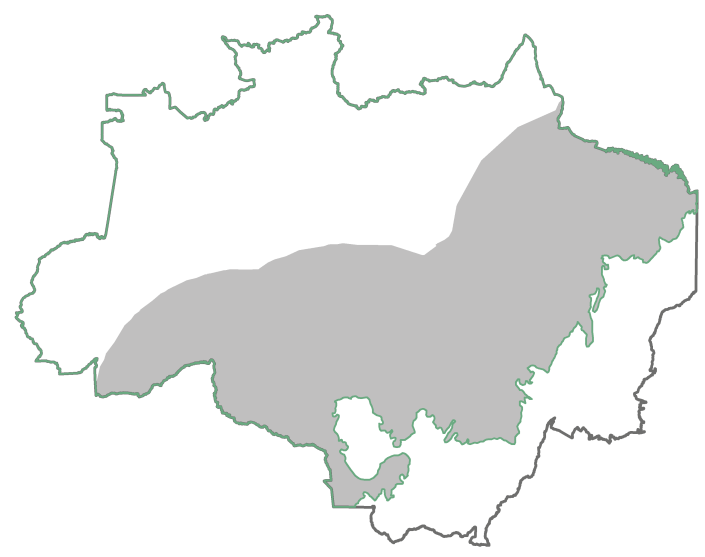

Legal Amazon border

Amazon biome border

sample for analysis

Notes: The map shows spatial boundaries for the Brazilian Legal Amazon and the Amazon biome, as well as for the analysis' spatial sample, which is defined as the area inside the Amazon biome that is within $750 \mathrm{~km}$ from its southeast border. Data sources: IBGE (Legal Amazon, Amazon biome).

Table 2.1: Sample Protection and Deforestation by Year

\begin{tabular}{|c|c|c|c|c|c|c|c|}
\hline \multirow{2}{*}{ year } & \multicolumn{3}{|c|}{ protected territory (ha) } & \multirow{2}{*}{$\begin{array}{l}\text { deforestation } \\
\text { (ha) }\end{array}$} & \multicolumn{3}{|c|}{ deforestation in protected territory (ha) } \\
\hline & strict & sustainable & indigenous & & strict & sustainable & indigenous \\
\hline 2006 & $14,390,361$ & $29,187,312$ & $43,760,741$ & 957,654 & 9,845 & 33,993 & 16,925 \\
\hline 2007 & $14,390,361$ & $31,468,158$ & $44,439,699$ & 993,454 & 7,813 & 91,605 & 19,935 \\
\hline 2008 & $16,908,733$ & $34,646,834$ & $44,602,169$ & $1,082,954$ & 11,311 & 65,311 & 30,395 \\
\hline 2009 & $17,348,376$ & $36,233,997$ & $44,891,184$ & 521,516 & 4,572 & 47,442 & 26,731 \\
\hline 2010 & $17,354,740$ & $36,235,850$ & $44,912,771$ & 481,134 & 3,144 & 38,771 & 12,718 \\
\hline 2011 & $17,420,710$ & $36,238,266$ & $45,103,968$ & 465,216 & 2,319 & 28,457 & 15,589 \\
\hline 2012 & $17,420,710$ & $36,238,347$ & $45,104,613$ & 359,672 & 2,793 & 27,550 & 11,302 \\
\hline 2013 & $17,420,710$ & $36,238,508$ & $45,104,613$ & 464,327 & 2,363 & 36,618 & 11,946 \\
\hline 2014 & $17,420,710$ & $36,238,508$ & $45,120,562$ & 409,924 & 1,364 & 38,156 & 5,743 \\
\hline
\end{tabular}

Notes: The table reports annual protected territory coverage by protection type, deforestation increment, and deforestation increment inside protected territory for the sample region. Data sources: FUNAI and ISA (indigenous lands); MMA (protected areas); PRODES/Inpe (deforestation).

\subsection{3}

\section{Descriptive Statistics}

At the $900 \mathrm{~m}$ resolution, the Amazon biome raster contains 5.2 million cells. As this implies a very high number of observations, limited computational capacity for calculating cell-level fixed effects estimators imposed a sample restriction. Figure 2.4 illustrates the spatial sample, defined as the region inside the Amazon biome that is within $750 \mathrm{~km}$ from its southeast border. ${ }^{12}$

The spatial sample contains $2,880,663$ cells. It extends over $55 \%$ of the

${ }^{12}$ Although the PPCDAm applied to the entire Brazilian Legal Amazon, over $90 \%$ of tropical deforestation over the past two decades was located inside the biome. 
Figure 2.5: Sample Protection and Deforestation

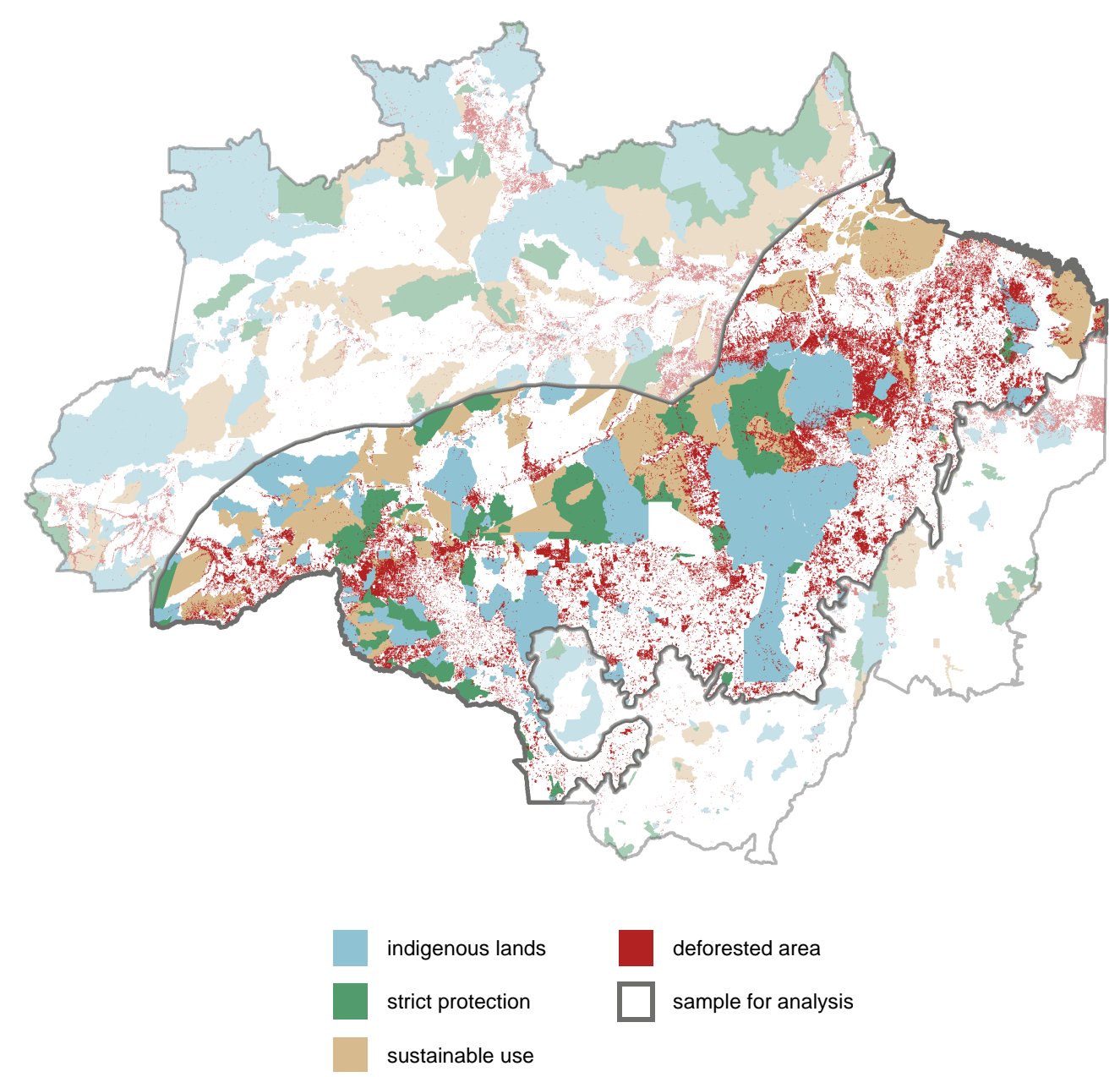

Notes: The map shows protected territory status by protection type in 2014, and total area deforested from 2007 through 2014. Dimmed regions are non-sample areas (see Section 2.4.3 for sample definition). Data sources: FUNAI and ISA (indigenous lands); MMA (protected areas); PRODES/Inpe (deforestation); IBGE (Legal Amazon, Amazon biome).

Amazon biome, and captures $45 \%$ of its protected territory (see Figure 2.5). The distribution of protection inside the sample is broadly representative of the Amazon, with protected areas for sustainable use and indigenous lands each covering about a fifth of the sample region, and strictly protected areas accounting for less than $10 \%$ of it. Table 2.1 presents protection coverage totals by type and year, showing that sample protected areas expanded by $20-25 \%$ from 2006 through 2014, while indigenous lands only grew by $3 \%$. This is consistent with Brazil's institutional framework, which allows for the creation of protected areas, but not of indigenous lands.

In contrast, deforestation during the sample period was greatly concentrated inside the sample region (see Figure 2.5). It held more than 95\% of total DETER alert area, and saw over 5.7 million hectares of cleared 
Table 2.2: Descriptive Statistics for Regression Variables

\begin{tabular}{|c|c|c|c|c|c|c|c|c|c|}
\hline & \multicolumn{9}{|c|}{ sample years } \\
\hline & 2006 & 2007 & 2008 & 2009 & 2010 & 2011 & 2012 & 2013 & 2014 \\
\hline \multicolumn{10}{|c|}{ deforestation increment ( $\%$ cell area) } \\
\hline mean & 0.0041 & 0.0043 & 0.0047 & 0.0022 & 0.0021 & 0.0020 & 0.0016 & 0.0020 & 0.0018 \\
\hline standard deviation & 0.0378 & 0.0377 & 0.0377 & 0.0244 & 0.0215 & 0.0219 & 0.0202 & 0.0241 & 0.0228 \\
\hline \multicolumn{10}{|c|}{ alerts $50 \mathrm{~km}$ ring (\% ring area) } \\
\hline mean & 0.0196 & 0.0099 & 0.0198 & 0.0118 & 0.0076 & 0.0086 & 0.0062 & 0.0073 & 0.0085 \\
\hline standard deviation & 0.0323 & 0.0153 & 0.0285 & 0.0173 & 0.0113 & 0.0139 & 0.0108 & 0.0130 & 0.0150 \\
\hline \multicolumn{10}{|c|}{ alerts $100 \mathrm{~km}$ ring ( $\%$ ring area) } \\
\hline mean & 0.0188 & 0.0098 & 0.0189 & 0.0117 & 0.0076 & 0.0086 & 0.0061 & 0.0072 & 0.0084 \\
\hline standard deviation & 0.0234 & 0.0107 & 0.0214 & 0.0114 & 0.0077 & 0.0098 & 0.0078 & 0.0094 & 0.0109 \\
\hline \multicolumn{10}{|l|}{$\mathrm{d}=1$ if protected cell } \\
\hline mean & 0.3668 & 0.3796 & 0.4021 & 0.4120 & 0.4122 & 0.4124 & 0.4124 & 0.4124 & 0.4125 \\
\hline standard deviation & 0.4819 & 0.4853 & 0.4903 & 0.4922 & 0.4922 & 0.4923 & 0.4923 & 0.4923 & 0.4923 \\
\hline \multicolumn{10}{|c|}{ unobservable PRODES (\% cell area) } \\
\hline mean & 0.0362 & 0.0268 & 0.0221 & 0.0346 & 0.0364 & 0.0271 & 0.0285 & 0.0467 & 0.0470 \\
\hline standard deviation & 0.1554 & 0.1259 & 0.1182 & 0.1506 & 0.1558 & 0.1318 & 0.1319 & 0.1727 & 0.1724 \\
\hline \multicolumn{10}{|c|}{ unobservable DETER (\% cell area) } \\
\hline mean & 0.3601 & 0.5842 & 0.4614 & 0.5468 & 0.4336 & 0.4650 & 0.3191 & 0.3257 & 0.4270 \\
\hline standard deviation & 0.0848 & 0.1317 & 0.2187 & 0.2106 & 0.2090 & 0.1687 & 0.1951 & 0.1972 & 0.2402 \\
\hline \multicolumn{10}{|l|}{ rainfall $(\mathrm{mm})$} \\
\hline mean & 2,254 & 2,135 & 2,162 & 2,223 & 2,015 & 2,157 & 2,080 & 2,215 & 2,181 \\
\hline \multirow{2}{*}{\multicolumn{10}{|c|}{ temperature (Celsius) }} \\
\hline & & & & & & & & & \\
\hline mean & 26.05 & 26.22 & 25.90 & 26.14 & 26.73 & 26.45 & 26.22 & 26.24 & 26.07 \\
\hline standa & 1.04 & 1.04 & 1.21 & 1.20 & 1.33 & 1.23 & 1.22 & 1.16 & 1.26 \\
\hline \multicolumn{10}{|c|}{$\mathrm{d}=1$ if DETER alert in cell } \\
\hline mean & 0.0198 & 0.0100 & 0.0202 & 0.0118 & 0.0076 & 0.0087 & 0.0062 & 0.0073 & 0.0085 \\
\hline standard deviation & 0.1394 & 0.0997 & 0.1407 & 0.1081 & 0.0870 & 0.0931 & 0.0785 & 0.0850 & 0.0917 \\
\hline \multicolumn{10}{|c|}{$\mathrm{d}=1$ if priority municipality } \\
\hline mean & 0.0000 & 0.0000 & 0.3142 & 0.3142 & 0.3479 & 0.3396 & 0.3506 & 0.3486 & 0.3294 \\
\hline standard deviation & 0.0000 & 0.0000 & 0.4642 & 0.4642 & 0.4763 & 0.4736 & 0.4772 & 0.4765 & 0.4700 \\
\hline
\end{tabular}

Notes: The table presents mean and standard deviations for variables used in the empirical analysis. Units are shown in parentheses; indicator variables are identified with " $\mathrm{d}=1$ ".

forest. As protection effectiveness crucially depends on local deforestation pressures, the sample region was intentionally designed to capture high-risk areas and, in doing so, assess protection's shielding capacity when faced with an actual threat. Table 2.1 provides annual areas cleared in the sample as a whole, as well as inside protected territory of each type.

Finally, Table 2.2 reports annual summary statistics for regression variables, showing that both the outcome of interest and key regressors exhibited cell-level variation across years.

\section{5}

Results

This section starts by empirically testing whether the intensity of neighborhood forest clearing alerts is associated with cell-level deforestation outcomes, and then builds on this to assess whether protection serves as a shield against forest loss. It follows with robustness checks, an investigation of heterogeneity across different types of protection and proximity to transport infrastructure, and closes with counterfactual exercises that 
hypothetically revoke protection.

\subsection{1}

\section{Main Results: Pressure and Protection}

In the current empirical setting, if neighboring forest clearing activity serves as a measure of local deforestation pressures, alert intensity in a cell's surroundings should have a non-null association with that cell's deforestation outcome. Table 2.3 presents estimated coefficients that test for the existence and reach of this association. Columns 1 through 3 only control for cell and year fixed effects, but gradually increase maximum neighborhood size in $50 \mathrm{~km}$ ring increments from $50 \mathrm{~km}$ through $150 \mathrm{~km}$; columns 4 and 5 hold maximum neighborhood size fixed, but gradually include cell-level geography and observed policy controls. Coefficients remain positive, statistically significant, and largely stable across specifications for the $50 \mathrm{~km}$ neighborhood, indicating that current clearing activity within $50 \mathrm{~km}$ of a cell are associated with increased future clearings inside that cell. Deforestation activity happening further away, beyond the $50 \mathrm{~km}$ neighborhood, does not appear to be associated with local clearing pressure. This is consistent with the idea that transportation within the Amazon is costly. As the region's vast dimensions are poorly connected by transport infrastructure, it is likely that deforestation operations are at least partially constrained by the feasibility of moving personnel, machinery, and goods across large distances. I therefore restrict the benchmark specification to a maximum ring distance of $100 \mathrm{~km}$, but only expect to see a shielding effect for protection through $50 \mathrm{~km}$. The negative, albeit less significant, coefficient for the $150 \mathrm{~km}$ neighborhood suggests a different effect might be in place for distant clearing activities, but offers little information as to what this effect might be. Because I use deforestation pressure as a tool through which to asses protected territory's shielding capacity, I delve no further into this negative effect, but conduct robustness checks to test whether it affects the analysis' key findings.

Having shown that forest clearing alerts within $50 \mathrm{~km}$ of a cell serve as a measure of local deforestation pressure, I now inspect whether protected and unprotected cells are equally affected by this pressure. If expected costs of engaging in forest clearing practices inside protected territory are higher, cell-level legal protection status should mitigate the positive relationship seen in Table 2.3. Unprotected territory is therefore expected to be more severely affected by advancing deforestation than protected territory. In light of this, Table 2.4 reports estimated coefficients for both neighborhood alert intensities and interaction terms between these intensities and cell protection 
Table 2.3: Neighborhood Clearing Activity and Local Deforestation Outcomes

\begin{tabular}{|c|c|c|c|c|c|}
\hline & \multicolumn{5}{|c|}{ deforestation increment in cell $(\mathrm{t})$} \\
\hline & (1) & $(2)$ & $(3)$ & $(4)$ & $(5)$ \\
\hline alerts $50 \mathrm{~km}(\mathrm{t}-1)$ & $\begin{array}{c}0.0338^{* *} \\
(0.0133)\end{array}$ & $\begin{array}{c}0.0339 * * \\
(0.0165)\end{array}$ & $\begin{array}{c}0.0332^{* *} \\
(0.0162)\end{array}$ & $\begin{array}{c}0.0334^{* *} \\
(0.0158)\end{array}$ & $\begin{array}{c}0.0306^{* *} \\
(0.0154)\end{array}$ \\
\hline alerts $100 \mathrm{~km}(\mathrm{t}-1)$ & & $\begin{array}{l}-0.0002 \\
(0.0117)\end{array}$ & $\begin{array}{c}0.0098 \\
(0.0102)\end{array}$ & $\begin{array}{c}0.0083 \\
(0.0100)\end{array}$ & $\begin{array}{c}0.0071 \\
(0.0098)\end{array}$ \\
\hline alerts $150 \mathrm{~km}(\mathrm{t}-1)$ & & & $\begin{array}{l}-0.0160 \\
(0.0122)\end{array}$ & $\begin{array}{l}-0.0185 \\
(0.0121)\end{array}$ & $\begin{array}{c}-0.0203^{*} \\
(0.0122)\end{array}$ \\
\hline R-squared & 0.0024 & 0.0024 & 0.0024 & 0.0033 & 0.0036 \\
\hline number of observations & $23,045,304$ & $23,045,304$ & $23,045,304$ & $23,045,304$ & $23,045,304$ \\
\hline number of cells & $2,880,663$ & $2,880,663$ & $2,880,663$ & $2,880,663$ & $2,880,663$ \\
\hline \multicolumn{6}{|l|}{ controls } \\
\hline cell fixed effects & yes & yes & yes & yes & yes \\
\hline year fixed effects & yes & yes & yes & yes & yes \\
\hline geography & no & no & no & yes & yes \\
\hline observed policy & no & no & no & no & yes \\
\hline
\end{tabular}

Notes: The table reports fixed effects coefficients for Equation 2-1 (Section 2.3). The dependent variable is the cell-level deforestation increment (deforested area in cell $i$ and year $t$ as a share of total cell area). Reported independent variables are neighborhood alert intensities in year $t-1$ (total alert area as a share of total neighborhood area). Maximum neighborhood size increases from $50 \mathrm{~km}$ (column 1) through $150 \mathrm{~km}$ (columns 2 through 3), and controls are added gradually to the specification with the maximum neighborhood (columns 4 and 5). The no/yes markers in bottom rows indicate the inclusion of the following sets of celllevel controls: (i) cell and year fixed effects; (ii) geography: measuring and monitoring satellite visibility, precipitation, and temperature; and (iii) observed policy: alert intensity, protection status, and priority municipality status. The cell-by-year panel includes 2,880,663 cells located within $750 \mathrm{~km}$ from the Brazilian Amazon biome southeast border and covers the 2006 through 2014 period. Standard errors are robust and clustered at the municipality level. Significance levels: ${ }^{* * *} \mathrm{p}<0.01,{ }^{* *} \mathrm{p}<0.05,{ }^{*} \mathrm{p}<0.10$.

status. Controls are included gradually to test the sensibility of results. The benchmark specification containing the full set of controls is presented in Table 2.4, column 3. Results show that, when exposed to the threat of deforestation, protected cells see significantly less forest clearings that similarly threatened unprotected ones. Again, estimated coefficients remain stable across the inclusion of controls, and clearing activity in the more distant neighborhood ring appears to have no significant effect on either protected or unprotected cells. Estimates indicate that the shielding effect is sizable. Under an increase of one standard deviation in the intensity of neighborhood alerts, the difference in clearings for unprotected and protected cells amounts to $3 \%$ of the sample standard deviation, or $26 \%$ of the sample mean.

Hence, at the cell level, legal protection seems to grant actual protection by serving as a shield against advancing forest clearings. This finding is consistent with Brazil's institutional framework, which implies a higher cost for clearing Amazon forest under protection due to both a greater chance of getting 
Table 2.4: Protected Territory as a Shield to Advancing Deforestation

\begin{tabular}{lccc}
\hline \hline & \multicolumn{3}{c}{ deforestation increment in cell (t) } \\
\cline { 2 - 4 } & $(1)$ & $(2)$ & $(3)$ \\
\hline & & & \\
alerts 50km (t-1) & $0.0376^{*}$ & $0.0376^{*}$ & $0.0347^{*}$ \\
alerts 50km * protected (t-1) & $(0.0204)$ & $(0.0197)$ & $(0.0191)$ \\
& $-0.0385^{*}$ & $-0.0376^{*}$ & $-0.0371^{* *}$ \\
alerts 100km (t-1) & $(0.0201)$ & $(0.0193)$ & $(0.0185)$ \\
& 0.0039 & 0.0021 & 0.0003 \\
alerts 100km * protected (t-1) & $(0.0161)$ & $(0.0150)$ & $(0.0147)$ \\
& -0.0079 & -0.0102 & -0.0117 \\
& $(0.0179)$ & $(0.0170)$ & $(0.0170)$ \\
\hline R-squared & & & \\
number of observations & 0.0025 & 0.0034 & 0.0036 \\
number of cells & $23,045,304$ & $23,045,304$ & $23,045,304$ \\
\hline controls & $2,880,663$ & $2,880,663$ & $2,880,663$ \\
\hline cell fixed effects & & & \\
year fixed effects & yes & yes & yes \\
geography & yes & yes & yes \\
observed policy & no & yes & yes \\
\hline \hline
\end{tabular}

Notes: The table reports fixed effects coefficients for Equation 2-1 (Section 2.3). The dependent variable is the cell-level deforestation increment (deforested area in cell $i$ and year $t$ as a share of total cell area). Reported independent variables are neighborhood alert intensities in year $t-1$ (total alert area as a share of total neighborhood area), and interaction terms between neighborhood alert intensities and cell protection status in year $t-1$ ( $\mathrm{d}=1$ if cell $i$ protected). All specifications contain both $50 \mathrm{~km}$ and $100 \mathrm{~km}$ neighborhood rings. The no/yes markers in bottom rows indicate the inclusion of the following sets of cell-level controls: (i) cell and year fixed effects; (ii) geography: measuring and monitoring satellite visibility, precipitation, and temperature; and (iii) observed policy: alert intensity, protection status, and priority municipality status. The cell-by-year panel includes 2,880,663 cells located within $750 \mathrm{~km}$ from the Brazilian Amazon biome southeast border and covers the 2006 through 2014 period. Standard errors are robust and clustered at the municipality level. Significance levels: ${ }^{* * *} \mathrm{p}<0.01,{ }^{* *} \mathrm{p}<0.05,{ }^{*} \mathrm{p}<0.10$.

caught and heavier penalties. Moreover, the evidence lends support to the action plan's novel siting strategy — protection effectively blocked advancing deforestation from moving into protected forests.

\subsection{2}

\section{Robustness: Extended Neighborhoods}

Results from Table 2.3 revealed that the relationship between neighborhood forest clearing activities and local deforestation pressures is not stable across increasingly distant neighborhoods. As a robustness check, I test whether the main finding that protection serves as a shield against advancing deforestation holds when accounting for alert intensity through extended neighborhoods. Even columns in Table 2.5 report results for 
Table 2.5: Robustness - Extended Neighborhoods

\begin{tabular}{|c|c|c|c|c|c|c|}
\hline & \multicolumn{6}{|c|}{ deforestation increment in cell $(\mathrm{t})$} \\
\hline & (1) & (2) & (3) & (4) & (5) & (6) \\
\hline alerts $50 \mathrm{~km}(\mathrm{t}-1)$ & $\begin{array}{c}0.0376^{*} \\
(0.0204)\end{array}$ & $\begin{array}{c}0.0373^{*} \\
(0.0202)\end{array}$ & $\begin{array}{l}0.0376^{*} \\
(0.0197)\end{array}$ & $\begin{array}{l}0.0372^{*} \\
(0.0195)\end{array}$ & $\begin{array}{l}0.0347^{*} \\
(0.0191)\end{array}$ & $\begin{array}{c}0.0343^{*} \\
(0.0189)\end{array}$ \\
\hline alerts $50 \mathrm{~km} *$ protected $(\mathrm{t}-1)$ & $\begin{array}{c}-0.0385^{*} \\
(0.0201)\end{array}$ & $\begin{array}{c}-0.0401^{* *} \\
(0.0201)\end{array}$ & $\begin{array}{c}-0.0376^{*} \\
(0.0193)\end{array}$ & $\begin{array}{c}-0.0395^{* *} \\
(0.0194)\end{array}$ & $\begin{array}{c}-0.0371^{* *} \\
(0.0185)\end{array}$ & $\begin{array}{c}-0.0393^{* *} \\
(0.0187)\end{array}$ \\
\hline alerts $100 \mathrm{~km}(\mathrm{t}-1)$ & $\begin{array}{c}0.0039 \\
(0.0161)\end{array}$ & $\begin{array}{c}0.0120 \\
(0.0148)\end{array}$ & $\begin{array}{c}0.0021 \\
(0.0150)\end{array}$ & $\begin{array}{c}0.0112 \\
(0.0142)\end{array}$ & $\begin{array}{c}0.0003 \\
(0.0147)\end{array}$ & $\begin{array}{c}0.0098 \\
(0.0140)\end{array}$ \\
\hline alerts $100 \mathrm{~km} *$ protected $(\mathrm{t}-1)$ & $\begin{array}{l}-0.0079 \\
(0.0179)\end{array}$ & $\begin{array}{l}-0.0022 \\
(0.0179)\end{array}$ & $\begin{array}{c}-0.0102 \\
(0.0170)\end{array}$ & $\begin{array}{l}-0.0043 \\
(0.0178)\end{array}$ & $\begin{array}{l}-0.0117 \\
(0.0170)\end{array}$ & $\begin{array}{l}-0.0035 \\
(0.0179)\end{array}$ \\
\hline alerts $150 \mathrm{~km}(\mathrm{t}-1)$ & & $\begin{array}{l}-0.0142 \\
(0.0182)\end{array}$ & & $\begin{array}{l}-0.0164 \\
(0.0176)\end{array}$ & & $\begin{array}{l}-0.0172 \\
(0.0172)\end{array}$ \\
\hline alerts $150 \mathrm{~km} *$ protected $(\mathrm{t}-1)$ & & $\begin{array}{l}-0.0050 \\
(0.0168)\end{array}$ & & $\begin{array}{l}-0.0049 \\
(0.0161)\end{array}$ & & $\begin{array}{l}-0.0078 \\
(0.0148)\end{array}$ \\
\hline R-squared & 0.0025 & 0.0025 & 0.0034 & 0.0034 & 0.0036 & 0.0036 \\
\hline number of observations & $23,045,304$ & $23,045,304$ & $23,045,304$ & $23,045,304$ & $23,045,304$ & $23,045,304$ \\
\hline number of cells & $2,880,663$ & $2,880,663$ & $2,880,663$ & $2,880,663$ & $2,880,663$ & $2,880,663$ \\
\hline \multicolumn{7}{|l|}{ controls } \\
\hline cell fixed effects & yes & yes & yes & yes & yes & yes \\
\hline year fixed effects & yes & yes & yes & yes & yes & yes \\
\hline geography & no & no & yes & yes & yes & yes \\
\hline observed policy & no & no & no & no & yes & yes \\
\hline
\end{tabular}

Notes: The table reports fixed effects coefficients for Equation 2-1 (Section 2.3). The dependent variable is the cell-level deforestation increment (deforested area in cell $i$ and year $t$ as a share of total cell area). Reported independent variables are neighborhood alert intensities in year $t-1$ (total alert area as a share of total neighborhood area), and interaction terms between neighborhood alert intensities and cell protection status in year $t-1$ ( $\mathrm{d}=1$ if cell $i$ protected). Odd columns replicate the gradual inclusion of controls in the benchmark specification from Table 2.4; even columns perform the same gradual inclusion of controls with an extended maximum neighborhood ring of $150 \mathrm{~km}$. The no/yes markers in bottom rows indicate the inclusion of the following sets of cell-level controls: (i) cell and year fixed effects; (ii) geography: measuring and monitoring satellite visibility, precipitation, and temperature; and (iii) observed policy: alert intensity, protection status, and priority municipality status. The cell-by-year panel includes 2,880,663 cells located within $750 \mathrm{~km}$ from the Brazilian Amazon biome southeast border and covers the 2006 through 2014 period. Standard errors are robust and clustered at the municipality level. Significance levels: ${ }^{* * *} \mathrm{p}<0.01,{ }^{* *} \mathrm{p}<0.05$, $* \mathrm{p}<0.10$.

specifications that use $150 \mathrm{~km}$ as the maximum neighborhood ring and gradually include the sets of controls. For comparison purposes, the table also reproduces coefficients from Table 2.3 in odd columns. Reassuringly, estimated coefficients remain largely robust both in magnitude and significance across specifications. Thus, accounting for clearing activities in more distant regions does not affect the finding that legal protection effectively protects territory within its domain from deforestation threats.

\subsection{3}

\section{Heterogeneity: Protection Type and Transportation Infrastructure}

This section individually explores two different dimensions of heterogeneity: protection type and proximity to transport infrastructure. So far, the analysis has treated protected territory as a single, uniform group. 
Table 2.6: Heterogeneity - Protection Types

\begin{tabular}{|c|c|c|c|}
\hline & \multicolumn{3}{|c|}{ deforestation increment in cell $(\mathrm{t})$} \\
\hline & (1) & $(2)$ & $(3)$ \\
\hline alerts $50 \mathrm{~km}(\mathrm{t}-1)$ & $\begin{array}{l}0.0368^{*} \\
(0.0200)\end{array}$ & $\begin{array}{c}0.0369^{*} \\
(0.0193)\end{array}$ & $\begin{array}{l}0.0341^{*} \\
(0.0187)\end{array}$ \\
\hline alerts $50 \mathrm{~km} *$ protected indigenous $(\mathrm{t}-1)$ & $\begin{array}{l}-0.0239 \\
(0.0205)\end{array}$ & $\begin{array}{l}-0.0222 \\
(0.0198)\end{array}$ & $\begin{array}{l}-0.0207 \\
(0.0189)\end{array}$ \\
\hline alerts $50 \mathrm{~km} *$ protected strict $(\mathrm{t}-1)$ & $\begin{array}{c}-0.0328^{*} \\
(0.0197)\end{array}$ & $\begin{array}{l}-0.0299 \\
(0.0193)\end{array}$ & $\begin{array}{l}-0.0331^{*} \\
(0.0190)\end{array}$ \\
\hline alerts $50 \mathrm{~km} *$ protected sustainable $(\mathrm{t}-1)$ & $\begin{array}{c}-0.0622^{* * *} \\
(0.0196)\end{array}$ & $\begin{array}{c}-0.0655^{* * *} \\
(0.0186)\end{array}$ & $\begin{array}{c}-0.0660 * * * \\
(0.0184)\end{array}$ \\
\hline alerts $100 \mathrm{~km}(\mathrm{t}-1)$ & $\begin{array}{c}0.0049 \\
(0.0155)\end{array}$ & $\begin{array}{c}0.0030 \\
(0.0145)\end{array}$ & $\begin{array}{c}0.0009 \\
(0.0142)\end{array}$ \\
\hline alerts $100 \mathrm{~km} *$ protected indigenous $(\mathrm{t}-1)$ & $\begin{array}{c}-0.0258^{*} \\
(0.0140)\end{array}$ & $\begin{array}{c}-0.0303^{* *} \\
(0.0132)\end{array}$ & $\begin{array}{c}-0.0333^{* *} \\
(0.0136)\end{array}$ \\
\hline alerts $100 \mathrm{~km} *$ protected strict $(\mathrm{t}-1)$ & $\begin{array}{l}-0.0048 \\
(0.0138)\end{array}$ & $\begin{array}{l}-0.0044 \\
(0.0136)\end{array}$ & $\begin{array}{c}0.0017 \\
(0.0139)\end{array}$ \\
\hline alerts $100 \mathrm{~km} *$ protected sustainable $(\mathrm{t}-1)$ & $\begin{array}{c}0.0417 \\
(0.0369)\end{array}$ & $\begin{array}{c}0.0470 \\
(0.0363)\end{array}$ & $\begin{array}{c}0.0491 \\
(0.0347)\end{array}$ \\
\hline $\begin{array}{l}\text { R-squared } \\
\text { number of observations } \\
\text { number of cells }\end{array}$ & $\begin{array}{c}0.0025 \\
23,045,304 \\
2,880,663\end{array}$ & $\begin{array}{c}0.0034 \\
23,045,304 \\
2,880,663\end{array}$ & $\begin{array}{c}0.0037 \\
23,045,304 \\
2,880,663\end{array}$ \\
\hline controls & & & \\
\hline cell fixed effects & yes & yes & yes \\
\hline year fixed effects & yes & yes & yes \\
\hline geography & no & yes & yes \\
\hline observed policy & no & no & yes \\
\hline
\end{tabular}

Notes: The table reports fixed effects coefficients for Equation 2-1 (Section 2.3). The dependent variable is the cell-level deforestation increment (deforested area in cell $i$ and year $t$ as a share of total cell area) Reported independent variables are neighborhood alert intensities in year $t-1$ (total alert area as a share of total neighborhood area), and interaction terms between neighborhood alert intensities and type-specific cell protection status in year $t-1$ ( $\mathrm{d}=1$ if cell $i$ protected). Protection types are indigenous lands (indigenous), strictly protected areas (strict), and protected areas for sustainable use (sustainable). The no/yes markers in bottom rows indicate the inclusion of the following sets of cell-level controls: (i) cell and year fixed effects; (ii) geography: measuring and monitoring satellite visibility, precipitation, and temperature; and (iii) observed policy: alert intensity, protection status, and priority municipality status. The cell-by-year panel includes 2,880,663 cells located within $750 \mathrm{~km}$ from the Brazilian Amazon biome southeast border and covers the 2006 through 2014 period. Standard errors are robust and clustered at the municipality level. Significance levels: ${ }^{* * *} \mathrm{p}<0.01,{ }^{* *} \mathrm{p}<0.05,{ }^{*} \mathrm{p}<0.10$.

Yet, Amazon protected territory is divided into three distinct categories: indigenous lands, strictly protected areas, and protected areas for sustainable use. These categories have been found to differ in terms of their impact on local deforestation outcomes, arguably due to their being allocated in regions under systematically lower or greater deforestation pressures (Nepstad et al., 2006; Nolte et al., 2013; Pfaff et al., 2014, 2015b). If a specific type of protected territory is located in a less risky area, its actual contribution to 
avoid deforestation in that area might be relatively smaller. Moreover, because each protection type has its own set of regulations regarding illegal forest conversion and associated punishments (see Section 2.2.3), the estimated shielding capacity for the full set of protected cells need not be homogeneous across protection types.

In light of this, I re-estimate protection shielding capacity, but now distinguish between the type of protection in each cell. Table 2.6 presents estimated coefficients under the gradual inclusion of controls. Shielding capacity varies across protection types. Although point estimates for this neighborhood's interaction coefficients are all negative, the shielding effect is stronger in magnitude and significance in protected areas for sustainable use. Strict protection provides some shielding, albeit at lower statistical significance, and indigenous lands do not appear to significantly block advancing clearings. Differences in regulation might explain the variation in shielding capacity across protection types, but the actual details of how different institutional settings influence shielding are yet to be understood. Finally, the significantly negative coefficient for the interaction between enforcement intensity in the outer $100 \mathrm{~km}$ ring and indigenous lands is a clear deviation from the pattern observed thus far. There is no evidence to suggest that a specific protection type was systematically assigned to more or less risky regions in the sample, so potential underlying reasons for this are still under investigation.

The second set of heterogeneity exercises assesses if shielding capacity varies according to the cell-level distance to transport infrastructure. As transportation within the Amazon is predominantly terrestrial, proximity to roads has been shown to be strongly correlated with deforestation outcomes and to drive relevant heterogeneity across the landscape (Angelsen and Kaimowitz, 1999; Chomitz and Thomas, 2003; Pfaff et al., 2007; Herrera, 2015; Pfaff et al., 2015b; Busch and Ferretti-Gallon, 2017). Data on road networks in the Brazilian Amazon come from the Brazilian National Department for Transport Infrastructure (DNIT) and are only available as a 2010 spatial cross-section. Table 2.7 presents estimated coefficients for specifications that include double and triple interactions with the cell-level distance to the nearest road. Results indicate that proximity to roads tends to nullify protection's shielding effect. This is more easily seen in Figure 2.6, which plots the difference in forest clearing outcomes between protected and unprotected cells under the same level of deforestation pressure along select percentiles of the distance to roads distribution. For cells that are very close to roads, protection seems to be incapable of holding back deforestation; as 
Table 2.7: Heterogeneity - Distance to Transport Infrastructure

\begin{tabular}{|c|c|c|}
\hline & \multicolumn{2}{|c|}{ deforestation increment in cell $(\mathrm{t})$} \\
\hline & $\begin{array}{c}(1) \\
\text { roads, all }\end{array}$ & $\begin{array}{c}(2) \\
\text { roads, paved }\end{array}$ \\
\hline alerts $50 \mathrm{~km}(\mathrm{t}-1)$ & $\begin{array}{l}-0.0097 \\
(0.0148)\end{array}$ & $\begin{array}{c}0.0260 \\
(0.0210)\end{array}$ \\
\hline alerts $50 \mathrm{~km} *$ protected $(\mathrm{t}-1)$ & $\begin{array}{l}-0.0106 \\
(0.0202)\end{array}$ & $\begin{array}{l}-0.0099 \\
(0.0226)\end{array}$ \\
\hline alerts $50 \mathrm{~km} *$ distance to road $(\mathrm{t}-1)$ & $\begin{array}{c}0.1548^{* * *} \\
(0.0435)\end{array}$ & $\begin{array}{c}0.0099 \\
(0.0110)\end{array}$ \\
\hline alerts $50 \mathrm{~km} *$ protected $*$ distance to road $(\mathrm{t}-1)$ & $\begin{array}{c}-0.1211^{* *} \\
(0.0508)\end{array}$ & $\begin{array}{l}-0.0239^{*} \\
(0.0127)\end{array}$ \\
\hline alerts $100 \mathrm{~km}(\mathrm{t}-1)$ & $\begin{array}{c}0.0164 \\
(0.0144)\end{array}$ & $\begin{array}{c}0.0274 \\
(0.0209)\end{array}$ \\
\hline alerts $100 \mathrm{~km} *$ protected $(\mathrm{t}-1)$ & $\begin{array}{l}-0.0028 \\
(0.0245)\end{array}$ & $\begin{array}{l}-0.0302 \\
(0.0318)\end{array}$ \\
\hline alerts $100 \mathrm{~km} *$ distance to road $(\mathrm{t}-1)$ & $\begin{array}{l}-0.0304 \\
(0.0276)\end{array}$ & $\begin{array}{c}-0.0357^{* *} \\
(0.0158)\end{array}$ \\
\hline alerts $100 \mathrm{~km} *$ protected $*$ distance to road $(\mathrm{t}-1)$ & $\begin{array}{l}-0.0108 \\
(0.0351)\end{array}$ & $\begin{array}{c}0.0276 \\
(0.0202)\end{array}$ \\
\hline $\mathrm{d}=1$ if protected $*$ distance to road $(\mathrm{t}-1)$ & $\begin{array}{c}0.0021^{* *} \\
(0.0009)\end{array}$ & $\begin{array}{c}-0.0024^{* *} \\
(0.0011)\end{array}$ \\
\hline $\mathrm{d}=1$ if alert issued $(\mathrm{t}-1)$ & $\begin{array}{c}0.0004 \\
(0.0007)\end{array}$ & $\begin{array}{c}0.0005 \\
(0.0007)\end{array}$ \\
\hline $\mathrm{d}=1$ if priority $(\mathrm{t}-1)$ & $\begin{array}{c}-0.0016^{* *} \\
(0.0006)\end{array}$ & $\begin{array}{c}-0.0017^{* *} \\
(0.0007)\end{array}$ \\
\hline $\mathrm{d}=1$ if protected $(\mathrm{t}-1)$ & $\begin{array}{l}-0.0005 \\
(0.0010)\end{array}$ & $\begin{array}{c}0.0034^{* * *} \\
(0.0009)\end{array}$ \\
\hline $\begin{array}{l}\text { R-squared } \\
\text { number of observations } \\
\text { number of cells }\end{array}$ & $\begin{array}{c}0.0040 \\
23,045,304 \\
2,880,663\end{array}$ & $\begin{array}{c}0.0037 \\
23,045,304 \\
2,880,663\end{array}$ \\
\hline controls & & \\
\hline $\begin{array}{l}\text { cell fixed effects } \\
\text { year fixed effects } \\
\text { geography } \\
\text { observed policy }\end{array}$ & $\begin{array}{l}\text { yes } \\
\text { yes } \\
\text { yes } \\
\text { yes }\end{array}$ & $\begin{array}{l}\text { yes } \\
\text { yes } \\
\text { yes } \\
\text { yes }\end{array}$ \\
\hline
\end{tabular}

Notes: The table reports fixed effects coefficients for Equation 2-1 (Section 2.3). The dependent variable is the cell-level deforestation increment (deforested area in cell $i$ and year $t$ as a share of total cell area). Reported independent variables are neighborhood alert intensities in year $t-1$ (total alert area as a share of total neighborhood area), and double and triple interaction terms between neighborhood alert intensities, cell protection status in year $t-1$ ( $\mathrm{d}=1$ if cell $i$ protected) and cell-level distance to nearest road (in $100 \mathrm{~km}$ ). Column headers indicate if specification refers to all roads (column 1) or only paved roads (column 2) The no/yes markers in bottom rows indicate the inclusion of the following sets of cell-level controls: (i) cell and year fixed effects; (ii) geography: measuring and monitoring satellite visibility, precipitation, and temperature; and (iii) observed policy: alert intensity, protection status, and priority municipality status. The cell-by-year panel includes 2,880,663 cells located within $750 \mathrm{~km}$ from the Brazilian Amazon biome southeast border and covers the 2006 through 2014 period. Standard errors are robust and clustered at the municipality level. Significance levels: ${ }^{* * *} \mathrm{p}<0.01,{ }^{* *} \mathrm{p}<0.05,{ }^{*} \mathrm{p}<0.10$. 
Figure 2.6: Impact Accounting for Distance to Transport Infrastructure

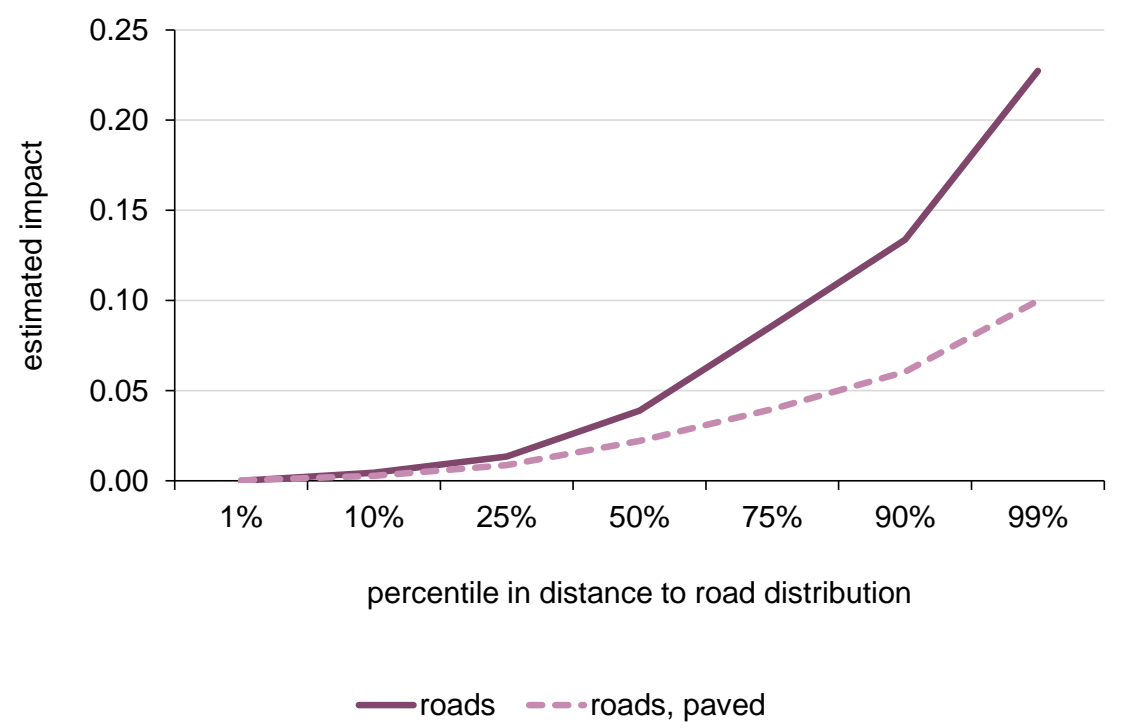

Notes: The graph plots the difference in forest clearing outcomes between protected and unprotected cells under the same level of deforestation pressure along select percentiles of the distance to roads distribution.

cells become more isolated from transport infrastructure, protection's shielding effect becomes increasingly more accentuated. This is an intuitive result considering that roads facilitate access to forest areas and might thereby increase deforestation risk. Figure 2.6 also shows that the influence of roads is not restricted solely to paved ones, corroborating the perception that the network of unpaved roads in the Amazon plays a relevant role in regional mobility.

\subsection{4}

\section{Counterfactual Exercises: Aggregate Deforested Area}

The cell-level analysis provides empirical evidence that protected territory serves as a local shield against deforestation pressures. Yet, to gain insight into the economic relevance of these cell-level effects, I conduct counterfactual exercises that explore deforestation trends under hypothetical scenarios that revoke protection. These exercises build on the benchmark specification (Table 2.4, column 3) to estimate cell-level forest clearing outcomes had protection never been assigned. In practice, this is performed by setting protection status variables to 0 across cells and years.

Figure 2.7 compares the total deforestation increment observed in sample protected territory with that estimated in the counterfactual scenario that revokes all Amazon protection. Counterfactual deforestation is systematically larger, indicating that these regions would have seen more forest clearings in the absence of protection's shielding effect. The difference between observed 
Figure 2.7: Counterfactual Exercise - No Protection

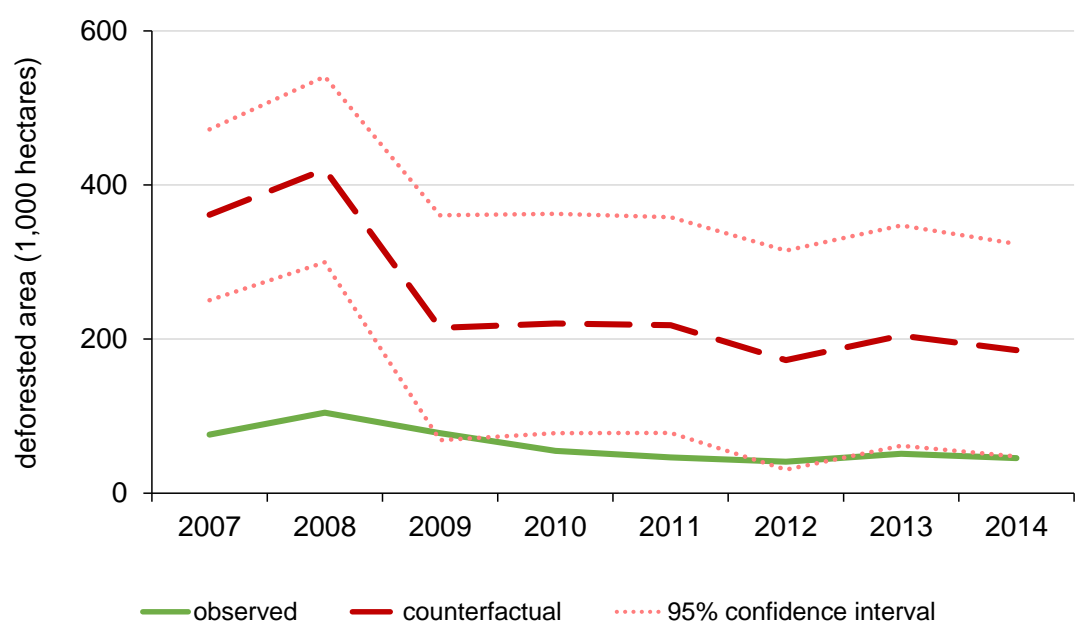

Notes: The graph plots annual deforestation in counterfactual and observed scenarios. The counterfactual scenario revokes all protected territory. Totals are calculated by adding the cell-level deforestation increment across sample cells that were under protection during part or all of the sample period.

Figure 2.8: Counterfactual Exercise - No Protection, by Type

(a) no indigenous lands

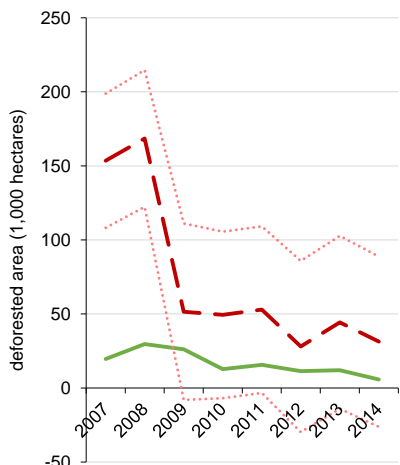

- observed (b) no strict protection

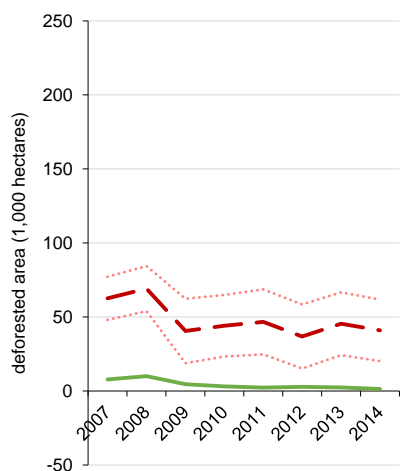

(c) no sustainable use

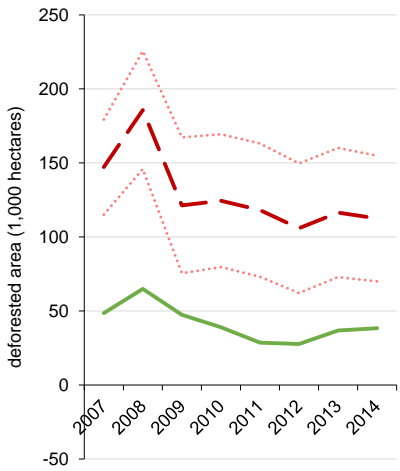

Notes: The graph plots annual deforestation in counterfactual and observed scenarios. The counterfactual scenarios revoke type-specific protected territory. Totals are calculated by adding the cell-level deforestation increment across sample cells that were under type-specific protection during part or all of the sample period.

and counterfactual deforestation is most significant in years of more intense deforestation activity, a finding that is consistent with the idea that protection serves as an effective shield insofar as areas under its domain face an actual threat.

To explore heterogeneity, this exercise is repeated for type-specific protection. Plots in Figure 2.8 are analogous to that of Figure 2.7, but each refers to a separate hypothetical scenario in which only type-specific protection is revoked. Again, protected areas exhibit stronger shielding capacity than indigenous lands, with counterfactual deforestation being 
Table 2.8: Counterfactual Exercise - No Protection, Full Sample Impact

\begin{tabular}{ccc}
\hline \hline year & \multicolumn{2}{c}{ deforested area (in hectares) } \\
\cline { 2 - 3 } & observed & $\begin{array}{c}\text { counterfactual: } \\
\text { no protection }\end{array}$ \\
\hline 2007 & $1,001,963$ & $1,010,052$ \\
2008 & $1,088,463$ & $1,083,634$ \\
2009 & 524,428 & 535,353 \\
2010 & 483,821 & 481,643 \\
2011 & 467,814 & 454,895 \\
2012 & 361,680 & 351,589 \\
2013 & 466,920 & 447,774 \\
2014 & 412,213 & 398,559 \\
\hline total & $4,807,300$ & $4,763,499$ \\
\hline \hline
\end{tabular}

Notes: The table reports annual deforestation in observed and counterfactual scenarios. The counterfactual scenario revokes all protected territory. Totals are calculated by adding the cell-level deforestation increment across all sample cells.

systematically and significantly larger than that observed across sample years. Thus, forests within the domain of strictly protected areas or protected areas for sustainable use would have suffered greater losses had it not been for legal protection. Indigenous lands, in contrast, appear to have benefited from shielding only in the very high-pressure years following the adoption of the PPCDAm. Although counterfactual deforestation under revoked indigenous lands is larger than observed, the difference between them is not statistically significant for most of the sample period.

Thus far, results corroborate protected territory's capacity to locally shield forest areas from deforestation pressures. Moreover, they serve as evidence that assigning protection to a given area influences the spatial dynamics of forest clearings in that area. This does not imply, however, that protection reduces aggregate deforestation levels. Table 2.8 reports annual deforested area in the sample, totaling deforestation outcomes in both protected and unprotected territories. There is remarkably little difference in forest loss between observed and hypothetical scenarios. As such, protection does not appear to reduce deforestation. Rather, it stands in the way of advancing clearings, which, instead of pushing forward into protected forest, then relocate to unprotected territory. Overall, these findings suggest that protection effectively deflects harm and thereby conserves the integrity of whatever lies under its domain - deflected deforestation, however, seems to finds its way to unshielded territory. 


\section{6}

\section{Final Remarks}

This analysis yields important policy implications that can potentially contribute to Brazil's goal of further reducing Amazon deforestation. The evidence that protected territories effectively shield forests within their domain from forest clearings attests to protection's effectiveness, and corroborates the action plan's use of these territories as a means of blocking advancing deforestation. Additionally, protected territories have been shown to influence regional deforestation dynamics. However, the finding that protection deflects clearings elsewhere points towards the need for policy interaction, as the strategic targeting of protected territory should be accompanied by complementary conservation efforts that effectively reduce deforestation. Exploring potential interactions could improve policy design, allowing policymakers to strengthen conservation by building on complementarities across interventions, eliminating redundancies, and mitigating potentially harmful impacts (Robalino et al., 2015; Pfaff and Robalino, 2017; Sims and Alix-Garcia, 2017). 


\section{Chapter 3 The Forest Awakens}

\section{1 \\ Introduction}

In the decade following the launch of the PPCDAm, Amazon conservation efforts were synonymous with fighting deforestation. These efforts were largely successful, directly contributing to a reduction in clearing rates of more than $80 \% .{ }^{1}$ While this remarkable deforestation slowdown drew vast attention from policymakers, academics, and the civil society, another no less remarkable - phenomenon occurred quietly (see Figure 3.1). The area covered by secondary vegetation in the Amazon increased by nearly $70 \%$, rising from less than 10 million hectares in 2004 to more than 17 million hectares ten years later (Inpe and Embrapa, 2016a). Secondary vegetation, defined as vegetation that grows in areas that have seen clear-cut deforestation, is a measure of regeneration. Thus, by 2014, nearly a quarter of the area historically cleared in the Brazilian Amazon already contained tropical forest regrowth.

That a phenomenon of this magnitude remained unnoticed seems unlikely; yet it is not an overstatement to claim that secondary vegetation was invisible from both policy and empirical perspectives. In its first decade, there were no policy efforts within the scope of the PPCDAm aimed at either promoting regeneration or protecting existing secondary vegetation. Remote sensing data on Amazon-wide regeneration was not available until the early 2010s, and - most importantly — Brazil's world-renowned satellite-based tropical forest monitoring systems, the key tools for effectively targeting Amazon law enforcement efforts, completely overlooked tropical regrowth.

This chapter explores the unique empirical setting of Amazon regeneration, particularly its invisibility to monitoring systems, to assess the existence of policy spillovers. In light of the improvement in law enforcement capacity brought about by the adoption of satellite-based high-frequency monitoring of deforestation activity, it proposes two alternative mechanisms

\footnotetext{
${ }^{1}$ See Chapter 1 for detailed descriptions of action plan policies and a survey of the associated evaluation literature.
} 
Figure 3.1: Brazilian Amazon Deforestation and Regeneration, 2000-2014

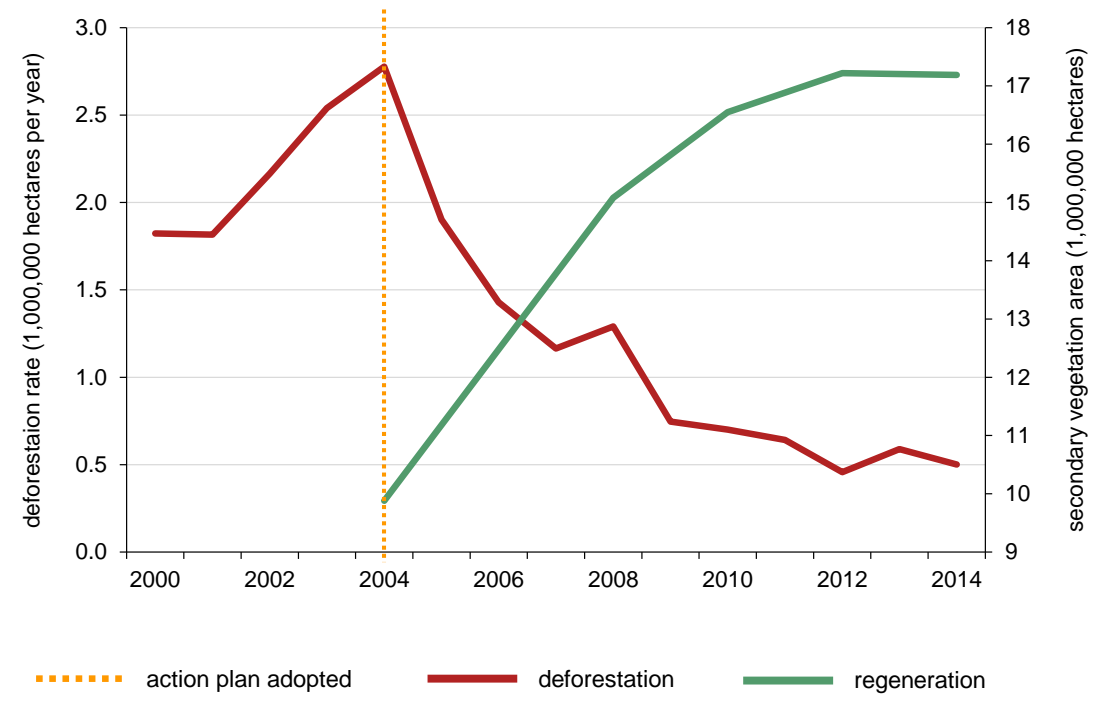

Notes: The graph plots the Brazilian Amazon annual deforestation rate and total secondary vegetation cover, and marks the year the action plan was launched. Secondary vegetation is defined as that which grows in deforested areas. Data sources: PRODES/Inpe (deforestation), TerraClass/Inpe and Embrapa (secondary vegetation).

for how environmental law enforcement targeting the clearing of primary (never deforested) vegetation might affect tropical regrowth. Both mechanisms relate the perceived risk of engaging in an illegal activity and the demand for deforested area. Clearing tropical forest without due licensing/authorization is illegal in the Brazilian Amazon, but so is using the land in areas that have been illegally deforested. ${ }^{2}$ As such, if stricter law enforcement increases the perceived risk of getting caught and punished for an environmental infraction, potential offenders might respond by altering both forest clearing and land use practices. On the one hand, offenders might seek to evade enforcement by shifting their activities to areas that are less likely to be targeted. In this scenario, instead of clearing primary forest and thereby risk getting caught by the monitoring system, offenders cut secondary forest and use these areas for production instead. Consequently, demand for previously deforested areas increases, and the extent of secondary vegetation decreases. On the other hand, enforcement might have a broad deterrence effect, causing offenders to give up on using deforested land altogether. With decreased demand for previously deforested areas, these areas are eventually abandoned, allowing a natural process of regeneration to take place and thereby increasing the extent of secondary vegetation. Hypothesized effects on regeneration in both displacement (the former) and

${ }^{2}$ See Section 2.2 for further details on deforestation as an illegal activity and associated criminal and administrative sanctioning. 
deterrence (the latter) scenarios constitute policy spillovers, as enforcement exclusively targeted the loss of primary vegetation and was not aimed at influencing forest regrowth. Yet, which mechanism dominates and, in fact, whether enforcement affected regeneration at all remain to be answered empirically.

I investigate the potential relationship between law enforcement and secondary vegetation using a spatially explicit dataset covering the full extent of the Brazilian Amazon. Although satellite-based panel data on regeneration serve as the basis for dataset construction, I argue that the long-term crosssectional difference in secondary vegetation area is less prone to measurement error than the time-series variation and is, thus, a preferable measure of the extent of regeneration. Because data on secondary vegetation are built from interpretation of satellite imagery, forest regrowth must be visible in the image. Yet, as imagery is inherently limited by the satellite's spatial resolution, it is plausible to expect that any given deforested area must accumulate sufficient natural biomass to be classified as secondary vegetation. Tropical regeneration is a time-consuming process that may take decades to occur in abandoned deforested areas (Alves et al., 1997; Aide et al., 2000; Guariguata and Ostertag, 2001), but data for secondary vegetation in the Amazon is only available for select years in the 2004 through 2014 period. Hence, to avoid noise from the time-series variation, I collapse the panel data into a crosssectional ten-year difference in secondary vegetation coverage. However, I still use information on the persistence of secondary vegetation to build an arguably more robust measure of regeneration and thereby mitigate concerns regarding misclassification of degraded forest.

Based on this spatial cross-sectional setup, and using georeferenced deforestation alerts to capture law enforcement, the analysis tests whether cell-level changes in the extent of secondary vegetation are associated with the intensity of environmental enforcement in a cell's surroundings. Results support the existence of both policy and spatial spillovers - enforcement activity happening within $20 \mathrm{~km}$ of a cell had a significant impact on regeneration outcomes inside that cell. The spillover effect is sizable. An increase of one standard deviation in the intensity of neighborhood enforcement is estimated to increase the probability of cell-level expansion in secondary vegetation coverage by $11 \%$ of the sample mean, and to increase the area of secondary vegetation inside the cell by $6 \%$ of the sample mean. Counterfactual exercises show that feasible improvements to Brazil's tropical forest monitoring system could contribute to increase secondary vegetation cover by nearly 300 thousand hectares. The overall stability of estimated 
coefficients across the inclusion of controls for spatially explicit observables suggests that the proposed strategy adequately addresses concerns regarding omitted variable bias. I interpret these findings as evidence that deforestation-oriented enforcement affected regeneration via the deterrence mechanism, in which environmental offenders, once faced with a higher perceived risk of illegal activity, abandon the region they are operating in and thereby allow a natural process of forest regrowth to occur.

The analysis also documents important heterogeneity across proximity to local remaining primary forest cover. The spillover effect of law enforcement on regeneration appears to be largest in places that have undergone neither too much nor too little deforestation: in the former, forest clearings and non-forest land use are probably more consolidated, making abandonment and subsequent regrowth less likely; in the latter, there is still relatively little area for the forest to grow back in.

Chapter 1 makes the case for the growing relevance of accounting for spillovers in the context of conservation policy impact evaluation (Baylis et al., 2016; Pfaff and Robalino, 2017). Several studies provide empirical evidence for the existence of conservation policy spillovers, but typically in contexts other than law enforcement. The most common examples are assessments of externalities from PES programs (Alix-Garcia et al., 2012, 2013; Jayachandran et al., 2017), and leakage or halo effects from protected territory (Herrera, 2015; Robalino et al., 2017). The literature assessing law enforcement under the PPCDAm has largely focused on the policy's direct impacts on deforestation. Although stricter enforcement has been shown to have significantly reduced Amazon forest clearings (Hargrave and Kis-Katos, 2013; Assunção et al., $2017 \mathrm{~b}$ ), it is the priority municipalities policy that, among all action plan efforts, has received most attention in the enforcement spillover literature. Results are mixed, with Cisneros et al. (2015) finding no evidence of the policy's deterrent effect on priority municipalities' neighbors, but both Andrade (2016) and Assunção et al. (2018b) documenting significant reductions in non-priority municipalities located near priority ones. To the best of my knowledge, this is the first assessment of tropical regeneration as a spillover of PPCDAm policies, and of law enforcement specifically, as well as the first study in the economic literature to explore the rich spatial data recently released on land use in Amazon deforested areas.

This analysis also speaks to a growing literature on the importance of tropical regeneration. The environmental services provided by secondary vegetation have been widely documented. These include, but are not limited to, carbon sequestration, reestablishment of hydrological services, soil protection, 
and creation of ecological corridors for fauna and flora (Almeida et al., 2010; Caviglia-Harris et al., 2015; Uriarte and Chazdon, 2016; Crouzeilles et al., 2017; Tyukavina et al., 2017). This chapter contributes to this literature by shedding light on how policy influences regeneration in an empirical setting where this phenomenon is happening at scale.

Finally, an important disclaimer is in order: this work in no way claims that primary and secondary forests are biologically or ecologically equivalent, nor does it mean to argue that regeneration makes up for the devastation caused to the Brazilian Amazon over years of predatory deforestation. Rather, its goal is to shed light upon a phenomenon which is sizable, ongoing, and largely unknown. A better understanding of the remarkable growth in tropical regeneration could help inform decision-makers, shape future policy, and ultimately contribute to ongoing efforts for conserving the Amazon forest while promoting regional development.

The chapter proceeds as follows: Section 3.2 describes the institutional context and proposes mechanisms through which, given this context, law enforcement could influence regeneration; Section 3.3 details the empirical strategy; Section 3.4 presents dataset and variable construction procedures; Section 3.5 reports and discusses estimation results and counterfactual simulations; and Section 3.6 concludes with policy implications.

\section{2 \\ Institutional Context}

Through 2014, tropical forest regrowth in the Amazon was largely invisible to conservation policy. This was partly due to a lack of available data. Indeed, through the early 2010s, Brazil had no system to track or measure Amazon-wide regeneration. The first map of tropical secondary vegetation, referring to land use in 2008, was only produced in 2012; it took another four years for data on 2004 and 2014 secondary vegetation cover to be released (see Appendix B.1.3). More importantly, perhaps, was the fact that, in its first decade, the PPCDAm neither promoted regeneration, nor explicitly sought to protect existing secondary vegetation. Rather, it focused exclusively on combating the clearing of primary vegetation. Considering the historically high rates of Amazon deforestation observed in the early 2000s, targeting primary forest loss seemed reasonable. Efforts undertaken within the scope of the conservation action plan were therefore built around containing primary forest clearings.

In light of this, and in a context of mostly illegal deforestation, improving environmental monitoring and law enforcement was a priority under the 
PPCDAm. The cornerstone of enforcement policy was DETER, the new satellite monitoring system. ${ }^{3}$ The adoption of DETER introduced near-realtime monitoring of forest disturbances, allowing Amazon clearings to be detected and acted upon in a more timely manner. By providing regular and high-frequency information on deforestation hot spots, it became the central tool for targeting law enforcement. However, the loss of secondary vegetation remained entirely invisible to DETER and, thus, to environmental authorities. Appendices B.1.1 and B.1.2 provide detailed explanations of the workings of Brazil's satellite-based systems to monitor and measure Amazon deforestation, but, crucial to this analysis, is the fact that the systems were built to detect solely the loss of primary vegetation. The country first started mapping Amazon deforestation the late 1980s. Since then, once an area of primary forest has been cleared, it is not revisited in future satellite imagery and becomes part of what is known as an accumulated deforestation mask. When introduced in the mid-2000s, DETER was designed to scan for signs of forest disturbance strictly outside this mask. Consequently, the loss of secondary vegetation is not accounted for in Amazon deforestation figures, nor does it trigger any forest clearing alerts in the DETER system.

This institutional setting suggests two alternative mechanisms for a potential effect of deforestation-oriented law enforcement on regeneration. On the one hand, stricter monitoring and enforcement enabled by DETER might have displaced demand for cleared areas towards secondary forest - I henceforth refer to this as the displacement channel. Because the system used to target enforcement does not detect secondary deforestation, there is a lower chance of an offender getting caught and punished if clearing secondary versus primary vegetation. Hence, a potential offender seeking to use cleared land in the Amazon could attempt to elude monitoring by shifting his deforestation activities to regenerated areas. In this scenario, one would expect to see a decrease in the extent of secondary vegetation.

Three elements arguably favored this change in forest clearing behavior. First, the extent of secondary vegetation was already sizable in the mid2000s (see Figure 3.1), providing ample supply of regenerated areas that were invisible to the monitoring system. Second, because secondary vegetation is typically sparser than primary forest, clearing these areas is likely easier and less costly. Finally, it could be argued that poorer soil quality in areas covered by secondary forest would limit displacement towards previously cleared areas, due to lower expected gains from land use. This, however, is most relevant to

\footnotetext{
${ }^{3}$ See Section 2.2 for a discussion about the predominantly illegal nature of Amazon forest clearings and a detailed description of the novel monitoring system.
} 
crop farming, which covered less than $6 \%$ of the area historically cleared in the Brazilian Amazon through 2014 (Inpe and Embrapa, 2016a). With over two thirds of Amazon deforested areas being used as pasture, which demands less nutrients from the soil, it seems reasonable to expect that potential offenders would seek to minimize their chance of getting caught, even if at a relatively minor cost to production. ${ }^{4}$

On the other hand, because using illegally cleared areas in the Amazon is illegal in and of itself, stricter monitoring and enforcement might have broadly inhibited illegal activity and thereby lowered the demand for deforested areas - I henceforth refer to this as the deterrence channel. Cleared areas that are no longer in use are often abandoned. This reduces human interference in these areas and allows a natural process of regeneration to occur. In this case, one would expect to see an increase in the extent of secondary vegetation.

The strong deterrent effect of law enforcement on aggregate primary deforestation documented in the literature (Hargrave and Kis-Katos, 2013; Assunção et al., 2017b) is consistent with either channel. If forest clearings displaced towards unmonitored areas to evade satellite-based law enforcement, Amazon secondary vegetation could have suffered significant losses after the introduction of the PPCDAm. Instead, tropical regeneration actually flourished in the action plan's first decade, increasing by about 7 million hectares (see Figure 3.1). This increase points towards a prevalence of the deterrence mechanism, but aggregate figures might hide underlying regional heterogeneity. Whether law enforcement influenced secondary vegetation at all and through which mechanisms remain to be answered by empirical assessments. As law enforcement exclusively targeted the clearing of primary vegetation, any significant effect of it on secondary vegetation regardless of the effect's sign - can be taken as evidence of policy spillovers.

\section{3}

\section{Empirical Strategy}

A key empirical challenge when looking at secondary vegetation as an outcome of interest is to account for the time it takes for a forest to regenerate. Tropical regrowth is a time-consuming phenomenon. The literature indicates that natural regeneration following the abandonment of once agricultural lands

\footnotetext{
${ }^{4}$ The case of Zona Bragantina, in eastern Pará state, indicates that the conversion of secondary forests into agricultural lands is not only a theoretical possibility, but a practical one. Vieira (2013) documents that, through 2008, the region saw reductions in both primary and secondary forest areas, alongside an increase in pasture areas in the 2000s. While not necessarily a response to enforcement activities, this anecdotal evidence supports the idea that the clearing of secondary forest areas can offer economically viable alternatives for agricultural production in the Brazilian Amazon.
} 
extends over several decades before aboveground biomass, stem density, and species richness are restored to mature forest levels, with estimates ranging from 30 to 40 years (Aide et al., 2000; Chazdon, 2008). Although reestablishing plant composition of old-growth forest is likely to take centuries (Guariguata and Ostertag, 2001), empirical assessments of Brazilian Amazon regeneration indicate that, 18 years after abandonment, secondary vegetation biomass was roughly half that of primary forest (Alves et al., 1997).

This has important implications for the detection of secondary forests in satellite imagery. Because clear-cut deforestation is a discrete process, it can be easily detected by comparing land cover images that refer to a short time difference, like a day. In contrast, regeneration is a continuous process that will only change incrementally over short periods of time. As satellite imagery is inherently limited by its spatial resolution, it is plausible to expect that any given deforested area must accumulate sufficient natural biomass to be classified as secondary vegetation during image interpretation. Shortterm time-series variation in regeneration data derived from remote sensing is therefore prone to measurement error. The proposed empirical strategy mitigates concerns about noisy time-series variation by using a long-term cross-sectional difference in secondary vegetation coverage as the outcome of interest. The section follows with a discussion of identification, and closes with details on implementation of the empirical strategy in the context of Amazon regeneration.

\subsection{1}

\section{Identification}

The empirical strategy aims at identifying if environmental law enforcement influenced tropical regeneration in a context in which secondary vegetation is invisible to monitoring systems used to target enforcement (see Section 3.2). To empirically explore the aforementioned displacement or deterrence mechanisms, the strategy tests if enforcement in a cell's neighborhood affected regeneration outcomes inside the cell. If found to be significant, estimated impacts serve as evidence of policy spillovers to the extent that enforcement during the period of interest was not aimed at either promoting or protecting secondary vegetation. In addition, significant results also point towards spatial spillovers, as they capture the effect of enforcement in one locality on regeneration outcomes in another.

The benchmark estimation equation is:

$$
\Delta_{\text {regeneration }}=\sum_{n \in \partial i} \beta_{n} \text { enforcement }_{n, i}+X_{i}^{\prime} \theta+\varepsilon_{i}
$$


where $\Delta$ regeneration $_{i}$ is the variation in regenerated area in cell $i$ over a given time period; for each of cell $i$ 's $n$ neighborhoods, en forcement ${ }_{n, i}$ is a measure of law enforcement intensity during the same time period; $X_{i}$ is a vector of cell-level controls for location, weather, satellite visibility, baseline deforested area, and observed conservation policy; and $\varepsilon_{i}$ is the cell-level idiosyncratic error. Estimates are robust to heteroskedasticity. For each cell, multiple neighborhoods are formed by concentric rings of increasing diameter around it. Coefficients $\beta_{n}$ therefore capture the average cell-level response of regeneration to enforcement occurring increasingly further away. If significant, $\beta_{n}<0$ indicates that spillovers occur via the displacement channel, in which demand for cleared land shifts towards regenerated areas, while $\beta_{n}>0$ lends support to the deterrence channel, in which previously cleared areas are abandoned and left to regenerate.

The validity of the identification strategy hinges on it adequately dealing with possible endogeneity between a cell's regeneration outcomes and law enforcement in its surroundings. Dataset construction is such that each of the cell's neighborhood rings contains neither the cell itself nor any of the smaller concentric rings (see Appendix A.1). The coefficients for neighborhood regressors therefore estimate the impact of an event occurring in the region outside a cell on an outcome observed inside that cell. The fact that Amazon regeneration is invisible to the satellite monitoring system reinforces this point, as it eliminates the risk of there being reverse causality between the outcome of interest and the key independent variables. Tackling omitted variable bias in this specification is less straightforward. As previously discussed, crosssectional time-difference data is more suitable to capture the response of a timeconsuming process like regeneration. This, however, prevents the use of fixed effects to address the reflection problem (Manski, 1993), making estimation more vulnerable to omitted variable bias. The proposed strategy mitigates this by including a host of cell-level controls (see Section 3.3.2). Although I cannot directly test whether potential sources of bias have been fully accounted for in the benchmark specification, the stability of estimated coefficients across the gradual inclusion of controls suggests that the analysis' main findings do not suffer from significant bias (see Section 3.5.1).

\subsection{2}

\section{Implementation}

The implementation of the proposed empirical strategy builds on the empirical setting for remote sensing-based measurement of Amazon regeneration. This setting drives the construction of two different outcome 
variables. First, as previously argued, the long-term cross-sectional difference in secondary vegetation coverage is a preferable measure for the extent of regeneration, as compared to potentially noisy short-term time-series variation. Panel data on Amazon regeneration are only available for select years from 2004 through 2014 (see Appendix B.1.3), such that outcome variables are determined as the cross-sectional ten-year (2004-2014) difference in cell-level secondary vegetation coverage. Yet, minor variations in this long-term difference might still capture inaccuracies from the satellite imagery interpretation procedure. To mitigate concerns about noisy measurements, the first dependent variable of interest is an indicator that flags whether expansion in regenerated area during the sample decade exceeded a minimum threshold. In benchmark specifications, it is set to $10 \%$ of cell area, equivalent to a sample average of 8.1 ha. Given the binary nature of this dependent variable, specifications that use it can be interpreted as linear probability models. I henceforth refer to this indicator as the probability-based dependent variable.

Second, the definition of secondary vegetation in the original data affects the interpretation of results. Appendix $\mathrm{C}$ provides a detailed account of the technical background to this discussion, but the logic can be summarized as follows. By construction, the original land use data do not distinguish between degraded primary forest and actual regeneration. Consequently, areas that are recorded as containing secondary vegetation might actually be covered by remaining primary vegetation, having seen no tropical regrowth at all. This is aggravated by the fact that tropical degradation is becoming increasingly relevant in the Brazilian Amazon (Souza Jr. et al., 2013; Rappaport et al., 2018). As the probability-based dependent variable does not distinguish between these two very different phenomena, a second dependent variable is built to address it. The proposed measure of non-decreasing secondary vegetation essentially sets a restrictive criteria for regeneration: once an area has been classified as secondary vegetation, it must remain as such throughout the remaining course of the time series. This measure is therefore more likely to capture actual tropical regrowth. The second dependent variables is the 2004 through 2014 cell-level difference in area of non-decreasing secondary vegetation. I henceforth refer to this indicator as the area-based dependent variable.

In practice, Equation 3-1 is estimated as:

$$
\text { regeneration }_{i}=\sum_{n \in \partial i} \beta_{n} \text { alerts }_{n, i}+X_{i}^{\prime} \theta+\varepsilon_{i}
$$

where $\Delta$ regeneration $_{i}$ is one of the two measures of secondary vegetation 
expansion in cell $i$ from 2004 through 2014; for each of cell $i$ 's $n$ neighborhoods, alerts $_{n, i}$ is a neighborhood-specific measure of forest clearing alert intensity; $X_{i}$ is the vector of cell-level controls for location (municipality, longitude/latitude), weather (temperature, precipitation), satellite visibility (visual obstructions in satellite imagery in 2004 and 2014), baseline deforested area (accumulated deforested area through 2003), and observed conservation policy (protected territory status, DETER alerts); and $\varepsilon_{i}$ is the cell-level idiosyncratic error.

The intensity of law enforcement in each neighborhood is calculated as total DETER alert area from 2006 through 2013 as a share of neighborhood area. A region with greater alert intensity is under greater deforestation pressure, but also more likely to be targeted by enforcement personnel. While the former pushes for broader clearing, the latter could deter activities that entail forest loss. The proposed strategy does not determine that alerts should exclusively capture one or the other; rather, it serves as an empirical test for which of these opposing forces prevail in practice.

Controls are either time-invariant, accumulated over the sample decade, or year-specific. Municipality indicators account for regional levels of regeneration, as affected by municipal initiatives and economic structure. To control for more specific geographic location and thereby for natural characteristics like soil quality and proximity to water, the specification includes a function of the cell's latitude/longitude coordinates including isolated, interaction, and quadratic terms. This saturated specification further adjusts for local levels of regeneration, and also addresses spatial dependence across cells in the same region. Weather variables account for average conditions that might favor or hinder tropical regeneration, while 2004 and 2014 satellite visibility controls address errors caused by obstructions blocking visual access to the Earth's surface in satellite imagery. The specification also includes total area cleared through 2003, as regeneration can only grow in deforested areas. While it would arguably be more intuitive to calculate the dependent variable as a share of deforested cell area in sample start and endpoints, endogeneity concerns keep me from doing so. Instead, dependent variables are stated as shares of cell area and the control for the baseline extent of deforestation is included. The last set of controls addresses conservation policies that might also contribute to regeneration. Policy controls include an indicator flagging whether the cell was protected at any point during the sample decade, as protection promotes isolation from human interference, and the total number of times the cell itself contained an alert, which serves as a measure of the intensity of local 
clearing activity.

Finally, implementation of the empirical strategy draws on one last aspect of the Amazon setting. The literature on ecological and biophysical determinants of regeneration shows that proximity to primary forest is a key driver of tropical regeneration (Crouzeilles et al., 2016; Latawiec et al., 2016; Uriarte and Chazdon, 2016). Although an in-depth assessment of the underlying mechanisms behind this relationship are outside the scope of this dissertation, the importance of primary forests can be broadly summarized by their role as sources of seeds and as habitats for animals that disperse seeds, pollinators, and predators of pathogens that threaten forest development. I account for the relevance of proximity to primary vegetation by building the benchmark sample from cells that contained at least $50 \%$ primary forest cover in 2004 (see Section 3.4.3). Robustness checks explore the sensitivity of results to variations in this primary forest cover threshold.

\section{4}

Data

The analysis is entirely based on spatial data that are publicly available from a variety of sources. This section provides a brief description of variables and presents descriptive statistics. The appendices contain detailed information on the empirical spatial setup (Appendix A), data sources (Appendix B), and data construction (Appendix C).

Particularly noteworthy for this chapter's analysis is the fact that the data for secondary vegetation cover in the Brazilian Amazon over the first decade of the PPCDAm are fairly new. To the best of my knowledge, this is the first empirical assessment that uses these data to explore how the action plan influenced Amazon regeneration.

\subsection{1}

\section{Main Variables}

Both probability- and area-based dependent variables are built from secondary vegetation data provided by Inpe's and Embrapa's TerraClass Amazônia (see Appendix B.1.3). Original panel data are made available as georeferenced rasters at the $30 \mathrm{~m}$ resolution. Minicell counts are used to calculate annual secondary vegetation coverage as a share of cell area and, subsequently, the 2004 through 2014 difference in regenerated cell share. This serves as the basis for the construction of an indicator variable that equals 1 if the ten-year difference is greater than or equal to 0.1 , and 0 otherwise. The indicator therefore signals whether secondary vegetation expanded over at least 
one tenth of the cell during the sample decade. The second outcome of interest uses non-decreasing secondary vegetation minicell counts to calculate the 2004 through 2014 difference in non-decreasing secondary vegetation coverage as a share of cell area (see Appendix C).

Although secondary vegetation might be maturing and growing in height during the sample period, the available data do not capture these changes. Fortunately, this does not pose a problem for identification. Because the exercise aims at detecting whether law enforcement pushed forest clearing into secondary vegetation or led to the abandonment of deforested areas and thereby allowed them to regenerate, interest lies in changes in the extent of regeneration, not its maturity or density.

The analysis uses spatial forest clearing alerts from Inpe's DETER system as a measure of the regional intensity of law enforcement (see Appendix B.1.2). ${ }^{5}$ As DETER alerts are used to target law enforcement, the greater the intensity of alerts in a given area, the more likely it is that law enforcers will visit that area. Monthly vector data on georeferenced alerts are rasterized at the $900 \mathrm{~m}$ resolution, such that a cell will take on a value of 1 if it contains an alert and a value of 0 otherwise. ${ }^{6,7}$ Neighborhood intensity is calculated as the total number of alert cells in each neighborhood over the 2006 through 2013 period as a share of total neighborhood cell count. ${ }^{8}$

\section{4 .2 \\ Controls}

The benchmark specification in Equation 3-2 includes five different sets of cell-level controls. First, it adds location controls for administrative divisions and a function of cell-level latitude/longitude. The analysis uses the 2007 Brazilian municipal division from IBGE to assign each cell to a single municipality. Latitude/longitude values refer to a cell's centroid.

\footnotetext{
${ }^{5}$ To the best of my knowledge, there is no available georeferenced data on enforcement deployment for the Brazilian Amazon.

${ }^{6}$ In practice, the rasterization algorithm assigns value 1 to a cell only if its centroid is contained within a polygon in the vector data. Because deforestation alerts can be as small as 25ha and the raster cells have an area of 81ha, running the algorithm on the raw vector resulted in the loss of a large amount of alerts. I therefore created a $1 \mathrm{~km}$ buffer around all alerts and only then rasterized the alert-plus-buffer vector data, thereby ensuring that if a cell fell within $1 \mathrm{~km}$ of an alert, it would be assigned value 1 during rasterization. For simplicity, I refer to this alert-plus-buffer area simply as the alert area throughout the chapter.

${ }^{7}$ There are a few occurrences of biweekly data, particularly in earlier DETER years. For a month with two deforestation alert datasets, I overlay the biweekly data to calculate total alert area for that month, as per Inpe's recommendation.

${ }^{8}$ Missing months in vector data indicate that no alerts were issued by DETER in that month.
} 
Second, monthly data compiled by Matsuura and Willmott (2015) serve as the basis for building weather controls. The authors use multiple sources of global weather data and apply geographic extrapolations to calculate a regular georeferenced world grid of estimated temperature and rainfall over land..$^{9}$ Data points in the original dataset refer to grid nodes, not cells, such that average annual temperature and total annual rainfall are calculated from the monthly data for each Amazon grid node. Because the spatial resolution for this dataset is much lower than $900 \mathrm{~m}$, cell weather values are the 2006 through 2013 averages of all grid node values within $180 \mathrm{~km}$ of each cell. ${ }^{10}$

Third, clouds, shadows cast by clouds, and smoke from forest fires can all affect visibility in satellite imagery and thereby introduce error in observed land use. Inpe releases information on land areas blocked from view in the $30 \mathrm{~m}$ raster TerraClass dataset (see Appendix B.1.3). Satellite visibility controls indicate the share of cell area suffering from visual obstructions in 2004 and 2014 .

Fourth, to account for the area where secondary forest could grow, the 2004 PRODES mask is used to capture baseline cell-level accumulated deforestation. This is calculated by adding across all 2004 TerraClass land use categories (including unobservable cells) in the $30 \mathrm{~m}$ raster, and is expressed as a share of total cell area.

Finally, observed policy controls address other conservation efforts that could affect local regeneration and regional law enforcement. Protected area data come from the MMA and indigenous lands data from Funai and ISA (see Appendix B.2). Protection status is captured by an indicator that flags whether a cell was under protection of any kind (indigenous lands, strictly protected areas, or protected areas for sustainable use) at any point from 2004 through 2014. The last control, the total number of DETER alerts issued in a cell from 2006 through 2013, is a measure of local forest clearing activity built from the same DETER dataset use to construct neighborhood enforcement intensities.

\subsection{3}

\section{Descriptive Statistics}

By definition, secondary vegetation can only grow in areas that have been deforested. The baseline sample therefore comprises all Amazon biome cells that contained non-null deforestation through 2003. This is equivalent to

\footnotetext{
${ }^{9}$ This database has been extensively used in the economic literature both to evaluate the impact of climate variables on economic outcomes and to provide relevant temperature and rainfall controls (Dell et al., 2014).

${ }^{10}$ This distance ensured all sample cells had non-missing weather data.
} 
Table 3.1: Sample Deforestation and Regeneration

\begin{tabular}{lccc}
\hline \hline & Brazilian Amazon & $\begin{array}{c}\text { baseline sample: } \\
\text { primary forest } \geq 0\end{array}$ & $\begin{array}{c}\text { benchmark sample: } \\
\text { primary forest } \geq 0.5\end{array}$ \\
\hline raster cell count (900m resolution) & - & $1,157,648$ & 403,191 \\
& & & \\
deforested area, historical through 2003 (ha) & $62,726,908$ & $55,762,471$ & $5,684,454$ \\
2004 secondary vegetation (ha) & $9,671,861$ & $9,307,164$ & $1,995,152$ \\
2004 non-decreasing secondary vegetation (ha) & - & $4,632,612$ & $1,126,561$ \\
& & & \\
deforested area, historical through 2013 (ha) & $74,261,876$ & $63,690,094$ & $10,322,528$ \\
2014 secondary vegetation (ha) & $17,305,640$ & $14,320,640$ & $3,445,083$ \\
2014 non-decreasing secondary vegetation (ha) & - & $9,607,376$ & $2,399,001$ \\
\hline \hline
\end{tabular}

Notes: The table reports total deforested and regenerated areas in the Brazilian Amazon, the baseline sample, and the benchmark sample. The baseline sample comprises all Amazon biome cells that contained non-null deforestation through 2003; the benchmark sample is a subset of this that is further restricted to cells that contained at least $50 \%$ primary forest cover in 2004. Areas for the Brazilian Amazon are calculated from vector data, while baseline and benchmark areas are calculated from the analysis' raster dataset. Nondecreasing secondary vegetation is a measure built for this empirical analysis (see Appendix C) and has therefore not been computed for the full extent of the Brazilian Amazon. Data sources: PRODES/Inpe (deforestation); TerraClass/Inpe and Embrapa (secondary vegetation).

selecting cells in the 2004 PRODES mask, which captures the area classified under TerraClass in 2004. The occurrence of deforestation is determined at the $30 \mathrm{~m}$ raster resolution, such that the sample includes all cells that contained at least one deforested minicell by 2003. Cells that first saw deforestation in 2004 or later are not included in the analysis to mitigate both endogeneity concerns and the chance of picking up on misclassified secondary vegetation. In light of the role played by proximity to primary vegetation in the regeneration process (see Section 3.3.2), the extent of remaining primary vegetation in the cell at baseline is used as an additional selection criteria for the benchmark sample. A cell that has seen little deforestation will likely contain more remaining primary vegetation, which typically favors tropical regrowth, but will also offer a relatively small area upon which secondary forest can grow. Because these effects pull in opposite directions, the benchmark sample is a subset of the baseline sample that is further restricted to cells containing at least 50\% primary forest cover in 2004. Primary forest cover data is also taken from the TerraClass 30m raster dataset (see Appendix B.1.1).

Table 3.1 summarizes deforestation and regeneration areas across the Brazilian Legal Amazon, the baseline sample, and the benchmark sample. Observed differences in areas across samples result from a combination of the following factors: (i) the Brazilian Legal Amazon is geographically larger than the Amazon biome (see Appendix A.2); (ii) conversion from vector to raster data might result in area discrepancies due to loss of overlapping areas and spatial precision; and (iii) baseline and benchmark samples exclude cells that contained null deforestation through 2003. The table also shows that the total 
Table 3.2: Descriptive Statistics for Regression Variables

\begin{tabular}{lcccccc}
\hline \hline & \multicolumn{2}{c}{ Brazilian } & Amazon & & \multicolumn{2}{c}{ benchmark sample } \\
\cline { 5 - 6 } & mean & std. dev. & & mean & std. dev. \\
\hline 2004 secondary vegetation (\% cell area) & 0.0220 & 0.0865 & & 0.0611 & 0.0862 \\
2004 non-decreasing secondary vegetation (\% cell area) & 0.0109 & 0.0565 & & 0.0345 & 0.0663 \\
2014 secondary vegetation (\% cell area) & 0.0366 & 0.1167 & & 0.1056 & 0.1274 \\
2014 non-decreasing secondary vegetation (\% cell area) & 0.0243 & 0.0887 & & 0.0735 & 0.1009 \\
& & & & & \\
d=1 if 2004-2014 $\Delta$ secondary vegetation $\geq 0.1$ cell area & 0.0630 & 0.2430 & & 0.2031 & 0.4023 \\
2004-2014 $\Delta$ secondary vegetation & 0.0146 & 0.0919 & & 0.0445 & 0.1181 \\
2004-2014 $\Delta$ non-decreasing secondary vegetation (\% cell area) & 0.0133 & 0.0605 & & 0.0390 & 0.0785 \\
& & & & & \\
alerts 5km neighborhood ring (\% ring area) & 0.0590 & 0.1920 & & 0.1809 & 0.3067 \\
alerts 10km neighborhood ring (\% ring area) & 0.0590 & 0.1576 & & 0.1608 & 0.2372 \\
alerts 20km neighborhood ring (\% ring area) & 0.0589 & 0.1327 & & 0.1429 & 0.1881 \\
alerts 50km neighborhood ring (\% ring area) & 0.0583 & 0.1039 & & 0.1173 & 0.1321 \\
alerts 100km neighborhood ring(\% ring area) & 0.0572 & 0.0819 & & 0.0962 & 0.0985 \\
& & & & & \\
2004 primary forest (\% cell area) & 0.7656 & 0.3853 & & 0.7958 & 0.1512 \\
total annual rainfall (mm) & & & & & \\
average annual temperature (Celsius) & 2326.69 & 448.39 & & 2182.20 & 368.65 \\
2004 unobservable TerraClass (\% cell area) & 26.41 & 0.98 & & 26.28 & 1.06 \\
2014 unobservable TerraClass (\% cell area) & 0.0108 & 0.0820 & & 0.0137 & 0.0553 \\
baseline accumulated deforestation (\% cell area) & 0.0070 & 0.0581 & & 0.0146 & 0.0682 \\
alert intensity (year average) & 0.1318 & 0.3040 & & 0.1742 & 0.1435 \\
d=1 if protected & 0.0590 & 0.3152 & & 0.2216 & 0.5766 \\
\hline \hline
\end{tabular}

Notes: The table presents mean and standard deviations for variables used in the empirical analysis. Units are shown in parentheses; indicator variables are identified with " $\mathrm{d}=1$ ".

extent of non-decreasing secondary vegetation in the analytical sample is not only sizable, but actually represents a relevant share of secondary vegetation area recorded in TerraClass: in 2004, it amounted to 4.6 million hectares, or about $50 \%$ of secondary vegetation observed in the baseline sample; in 2014, it had increased to 9.6 million hectares, totaling $67 \%$ of secondary vegetation observed in the baseline sample. Because the baseline sample excludes cells that were first deforested in 2004 or later, secondary vegetation recorded in TerraClass for the baseline sample in 2014 totals about 14.3 million hectares, not the 17 million hectares observed for the entire Brazilian Amazon (see Figure 3.1).

Table 3.2 presents mean and standard deviations for variables used in the regression analysis, including statistics for the Amazon biome for comparison with the benchmark sample. The sample selection criteria implies higher average cell-level secondary vegetation coverage and neighborhood alert intensities. This is to be expected considering that cells that have never been deforested have, by definition, null secondary vegetation. Moreover, statistics for the full Amazon make no distinction between high and low deforestation pressure zones, whereas the benchmark selection of cells that had seen some deforestation but still contained primary forest area at baseline 
likely captures high-risk areas. Hence, although the benchmark sample might not be representative of the Brazilian Amazon as a whole from the perspective of descriptive statistics, it ensures the analysis is focused on areas that were actual candidates for seeing an impact of neighboring enforcement on local regeneration. Table 3.2 also indicates that the sample exhibits relevant crosssectional variation.

Finally, descriptive statistics regarding changes in agricultural land use from 2004 through 2014 shed light on where regeneration was happening. In the baseline sample, $65 \%$ of cells where the expansion in secondary vegetation was greater than 10\% saw a reduction in pasture area, and $50 \%$ of cells where non-decreasing secondary vegetation area grew saw this same reduction. In the benchmark sample, the analogous figures are $45 \%$ and $35 \%$, respectively. Cropland, however, saw a reduction in only a tiny fraction of cells across samples. These statistics are aligned with official Amazon-wide transitions across TerraClass categories, which indicate that $33 \%$ of pasture and virtually 0\% of cropland in 2004 contained regeneration in 2014 (Inpe and Embrapa, 2016b). Thus, the expansion of secondary vegetation appears to have occurred, in its vast majority, over pasture areas.

\section{5 \\ Results}

This section starts by empirically testing the existence and reach of environmental law enforcement in a cell's neighborhood on regeneration outcomes inside the cell. It then follows with robustness checks that use alternative thresholds for defining dependent variables and samples, as well as tests for additional controls. To shed light on aggregate impacts, the section closes with counterfactual exercises that explore variations in monitoring technology.

\subsection{1}

\section{Main Results: Policy Spillovers}

If environmental law enforcement targeting primary deforestation affects tropical regeneration via either displacement or deterrence mechanisms, enforcement in one locality should significantly impact regeneration elsewhere. Table 3.3 presents estimated coefficients under the inclusion of increasingly distant neighborhoods to establish the catchment area, or reach, of this potential spillover effect. ${ }^{11}$ Column 1 starts with only

\footnotetext{
${ }^{11}$ In the hot spot policing literature, an intervention's catchment area is that within which spillovers occur (Braga et al., 1999; Braga and Bond, 2008; Taylor et al., 2011; Blattman et al., 2017). Although there are different ways to model spillovers, this literature often
} 
the nearest $5 \mathrm{~km}$ neighborhood, and columns 2 through 5 gradually add regressors for enforcement intensity in $10 \mathrm{~km}, 20 \mathrm{~km}, 50 \mathrm{~km}$, and $100 \mathrm{~km}$ neighborhoods, respectively. Coefficients in Panel A capture the impact of enforcement on the indicator variable flagging whether the 2004 through 2014 difference in secondary vegetation area was equal to or greater than one tenth of cell area, and can therefore be interpreted as differences in the probability of seeing regeneration expand over a minimum cell area threshold. Coefficients in Panel B capture the 2004 through 2014 difference in non-decreasing secondary vegetation area as a share of cell area, and can therefore be interpreted as actual area effects. All columns include the full set of cell-level controls: location (municipality, saturated longitude/latitude), weather (temperature, precipitation), satellite visibility (visual obstructions in satellite imagery in 2004 and 2014), baseline deforested area (accumulated deforestation through 2003), and observed conservation policy (protected territory status, DETER alerts). Results indicate that cell regeneration is significantly affected by enforcement activity located within $20 \mathrm{~km}$, but not farther. This holds for both dependent variables, which also exhibit fairly stable coefficients across columns.

Identification of the proposed empirical strategy ultimately depends on adequately controlling for potential sources of bias (see Section 3.3.1). In light of this, Table 3.4 reports estimated coefficients for an uncontrolled specification (column 1), as well as for the gradual inclusion of five sets of controls: location (column 2), weather (column 3), satellite visibility (column 4), baseline deforested area (column 5), and observed conservation policy (column 6). Results show that it is important to control for location, including both municipality and a saturated function of cell centroid coordinates, as expected. Reassuringly, coefficients are largely stable across the inclusion of additional controls, lending support to the proposed identification strategy. Beyond location controls, the baseline deforested area control is perhaps that which affects estimated coefficients most markedly. This is consistent with the fact that the extent of existing deforestation at baseline captures an important aspect of potential regeneration.

Henceforth, the analysis focuses on the specification with the full set of controls (Table 3.4, column 6). Estimated coefficients point towards significant spillovers, with environmental law enforcement targeting loss of primary vegetation having had a positive impact on tropical regeneration more intense enforcement activity in a cell's neighborhood was associated defines catchment areas as one fixed-width ring or several concentric rings (with increasing radii) around a given region. 
Table 3.3: Catchment Area for Law Enforcement Spillover on Regeneration

\begin{tabular}{|c|c|c|c|c|c|}
\hline & $(1)$ & $(2)$ & (3) & (4) & (5) \\
\hline \multicolumn{6}{|c|}{ Panel $A: P(\Delta$ secondary vegetation $\geq 0.1$ cell area $)$} \\
\hline alerts $5 \mathrm{~km}$ & $\begin{array}{c}0.0489^{* * *} \\
(0.0032)\end{array}$ & $\begin{array}{c}0.0203^{* * *} \\
(0.0041)\end{array}$ & $\begin{array}{c}0.0216^{* * *} \\
(0.0041)\end{array}$ & $\begin{array}{c}0.0216^{* * *} \\
(0.0041)\end{array}$ & $\begin{array}{c}0.0216^{* * *} \\
(0.0041)\end{array}$ \\
\hline alerts $10 \mathrm{~km}$ & & $\begin{array}{c}0.0537^{* * *} \\
(0.0051)\end{array}$ & $\begin{array}{c}0.0271^{* * *} \\
(0.0062)\end{array}$ & $\begin{array}{c}0.0272^{* * *} \\
(0.0062)\end{array}$ & $\begin{array}{c}0.0272^{* * *} \\
(0.0062)\end{array}$ \\
\hline alerts $20 \mathrm{~km}$ & & & $\begin{array}{c}0.0532^{* * *} \\
(0.0072)\end{array}$ & $\begin{array}{c}0.0519 * * * \\
(0.0079)\end{array}$ & $\begin{array}{c}0.0519^{* * *} \\
(0.0080)\end{array}$ \\
\hline alerts $50 \mathrm{~km}$ & & & & $\begin{array}{c}0.0042 \\
(0.0115)\end{array}$ & $\begin{array}{c}0.0045 \\
(0.0121)\end{array}$ \\
\hline alerts $100 \mathrm{~km}$ & & & & & $\begin{array}{l}-0.0018 \\
(0.0188)\end{array}$ \\
\hline R-squared & 0.1208 & 0.1211 & 0.1212 & 0.1212 & 0.1212 \\
\hline \multicolumn{6}{|c|}{ Panel B: $\Delta$ non-decreasing secondary vegetation (\% cell area) } \\
\hline alerts $5 \mathrm{~km}$ & $\begin{array}{c}0.0035^{* * *} \\
(0.0006)\end{array}$ & $\begin{array}{l}-0.0001 \\
(0.0008)\end{array}$ & $\begin{array}{c}0.0001 \\
(0.0008)\end{array}$ & $\begin{array}{c}0.0001 \\
(0.0008)\end{array}$ & $\begin{array}{c}0.0001 \\
(0.0008)\end{array}$ \\
\hline alerts $10 \mathrm{~km}$ & & $\begin{array}{c}0.0068^{* * *} \\
(0.0010)\end{array}$ & $\begin{array}{c}0.0030^{* *} \\
(0.0012)\end{array}$ & $\begin{array}{c}0.0030^{* *} \\
(0.0012)\end{array}$ & $\begin{array}{r}0.0030^{* *} \\
(0.0012)\end{array}$ \\
\hline alerts $20 \mathrm{~km}$ & & & $\begin{array}{c}0.0076^{* * *} \\
(0.0014)\end{array}$ & $\begin{array}{c}0.0075^{* * *} \\
(0.0016)\end{array}$ & $\begin{array}{c}0.0077^{* * *} \\
(0.0016)\end{array}$ \\
\hline alerts $50 \mathrm{~km}$ & & & & $\begin{array}{c}0.0002 \\
(0.0022)\end{array}$ & $\begin{array}{l}-0.0004 \\
(0.0023)\end{array}$ \\
\hline alerts $100 \mathrm{~km}$ & & & & & $\begin{array}{c}0.0038 \\
(0.0036)\end{array}$ \\
\hline R-squared & 0.1403 & 0.1404 & 0.1404 & 0.1404 & 0.1405 \\
\hline $\begin{array}{l}\text { number of observations } \\
\text { controls }\end{array}$ & 403,191 & 403,191 & 403,191 & 403,191 & 403,191 \\
\hline municipality & yes & yes & yes & yes & yes \\
\hline coordinates (lon, lat, lon $^{2}$, lat $^{2}$, lon*lat) & yes & yes & yes & yes & yes \\
\hline weather & yes & yes & yes & yes & yes \\
\hline satellite visibility & yes & yes & yes & yes & yes \\
\hline baseline accumulated deforestation & yes & yes & yes & yes & yes \\
\hline observed conservation policy & yes & yes & yes & yes & yes \\
\hline
\end{tabular}

Notes: The table reports OLS coefficients for Equation 3-2 (Section 3.3.2). The dependent variable differs across panels: an indicator for secondary vegetation expansion $(\mathrm{d}=1$ if the 2004 through 2014 difference in secondary vegetation coverage $\geq 0.1$ of cell area) in Panel A; non-decreasing secondary vegetation expansion (the 2004 through 2014 difference in non-decreasing secondary vegetation coverage as a share of cell area) in Panel B. Reported independent variables are neighborhood alert intensities (2006 through 2013 total alert area as a share of total neighborhood area). Maximum neighborhood size increases from $5 \mathrm{~km}$ (column 1) through $100 \mathrm{~km}$ (column 5). The no/yes markers in bottom rows indicate the inclusion of the following sets of cell-level controls: (i) location: municipality, saturated function of cell longitude/latitude; (ii) weather: average annual temperature, total annual precipitation; (iii) satellite visibility: visual obstructions in satellite imagery in 2004 and 2014; (iv) baseline deforested area: accumulated deforestation through 2003; and (v) observed conservation policy: protected territory status, alert intensity. The cross-sectional sample is built from 2004 through 2014 panel data. It includes all 403,191 Amazon biome cells that contained non-null deforestation through 2003 and at least $50 \%$ primary forest cover in 2004. Standard errors are robust to heteroskedasticity. Significance: ${ }^{* * *} \mathrm{p}<0.01,{ }^{* *} \mathrm{p}<0.05,{ }^{*} \mathrm{p}<0.10$.

with both a greater probability of seeing cell-level growth in secondary vegetation coverage, and a larger expansion in non-decreasing secondary vegetation at the cell level. The spillover effect is sizable. An increase of one standard deviation in the intensity of neighborhood enforcement increases 
Table 3.4: Law Enforcement Spillover on Regeneration

\begin{tabular}{|c|c|c|c|c|c|c|}
\hline & $(1)$ & $(2)$ & $(3)$ & $(4)$ & $(5)$ & $(6)$ \\
\hline \multicolumn{7}{|c|}{ Panel A: $P(\Delta$ secondary vegetation $\geq 0.1$ cell area $)$} \\
\hline alerts $5 \mathrm{~km}$ & $\begin{array}{c}0.0034 \\
(0.0035)\end{array}$ & $\begin{array}{c}0.0136^{* * *} \\
(0.0035)\end{array}$ & $\begin{array}{c}0.0136^{* * *} \\
(0.0035)\end{array}$ & $\begin{array}{c}0.0180^{* * *} \\
(0.0035)\end{array}$ & $\begin{array}{c}0.0282^{* * *} \\
(0.0035)\end{array}$ & $\begin{array}{c}0.0216^{* * *} \\
(0.0041)\end{array}$ \\
\hline alerts $10 \mathrm{~km}$ & $\begin{array}{c}0.0188^{* * *} \\
(0.0063)\end{array}$ & $\begin{array}{c}0.0246^{* * *} \\
(0.0061)\end{array}$ & $\begin{array}{c}0.0246^{* * *} \\
(0.0061)\end{array}$ & $\begin{array}{c}0.0252^{* * *} \\
(0.0061)\end{array}$ & $\begin{array}{c}0.0257^{* * *} \\
(0.0061)\end{array}$ & $\begin{array}{c}0.0272^{* * *} \\
(0.0062)\end{array}$ \\
\hline alerts $20 \mathrm{~km}$ & $\begin{array}{c}0.0540^{* * *} \\
(0.0080)\end{array}$ & $\begin{array}{c}0.0630^{* * *} \\
(0.0080)\end{array}$ & $\begin{array}{c}0.0628^{* * *} \\
(0.0080)\end{array}$ & $\begin{array}{c}0.0622^{* * *} \\
(0.0080)\end{array}$ & $\begin{array}{c}0.0540^{* * *} \\
(0.0079)\end{array}$ & $\begin{array}{c}0.0519^{* * *} \\
(0.0080)\end{array}$ \\
\hline alerts $50 \mathrm{~km}$ & $\begin{array}{l}-0.0165 \\
(0.0110)\end{array}$ & $\begin{array}{c}0.0250^{* *} \\
(0.0121)\end{array}$ & $\begin{array}{c}0.0241^{* *} \\
(0.0121)\end{array}$ & $\begin{array}{c}0.0294^{* *} \\
(0.0121)\end{array}$ & $\begin{array}{c}0.0077 \\
(0.0120)\end{array}$ & $\begin{array}{c}0.0045 \\
(0.0121)\end{array}$ \\
\hline alerts $100 \mathrm{~km}$ & $\begin{array}{c}0.0105 \\
(0.0108)\end{array}$ & $\begin{array}{c}0.0085 \\
(0.0189)\end{array}$ & $\begin{array}{c}0.0092 \\
(0.0191)\end{array}$ & $\begin{array}{c}0.0171 \\
(0.0190)\end{array}$ & $\begin{array}{c}0.0024 \\
(0.0188)\end{array}$ & $\begin{array}{l}-0.0018 \\
(0.0188)\end{array}$ \\
\hline R-squared & 0.0012 & 0.0679 & 0.0679 & 0.0975 & 0.1212 & 0.1212 \\
\hline \multicolumn{7}{|c|}{ Panel B: $\Delta$ non-decreasing secondary vegetation ( $\%$ cell area) } \\
\hline alerts $5 \mathrm{~km}$ & $\begin{array}{c}-0.0063^{* * *} \\
(0.0007)\end{array}$ & $\begin{array}{c}-0.0058^{* * *} \\
(0.0007)\end{array}$ & $\begin{array}{c}-0.0058^{* * *} \\
(0.0007)\end{array}$ & $\begin{array}{c}-0.0041^{* * *} \\
(0.0007)\end{array}$ & $\begin{array}{c}-0.0021^{* * *} \\
(0.0007)\end{array}$ & $\begin{array}{c}0.0001 \\
(0.0008)\end{array}$ \\
\hline alerts $10 \mathrm{~km}$ & $\begin{array}{c}0.0026^{* *} \\
(0.0013)\end{array}$ & $\begin{array}{c}0.0036^{* * *} \\
(0.0012)\end{array}$ & $\begin{array}{c}0.0036^{* * *} \\
(0.0012)\end{array}$ & $\begin{array}{c}0.0037^{* * *} \\
(0.0012)\end{array}$ & $\begin{array}{c}0.0038^{* * *} \\
(0.0012)\end{array}$ & $\begin{array}{c}0.0030^{* *} \\
(0.0012)\end{array}$ \\
\hline alerts $20 \mathrm{~km}$ & $\begin{array}{c}0.0095^{* * *} \\
(0.0016)\end{array}$ & $\begin{array}{c}0.0095^{* * *} \\
(0.0016)\end{array}$ & $\begin{array}{c}0.0093^{* * *} \\
(0.0016)\end{array}$ & $\begin{array}{c}0.0091^{* * *} \\
(0.0016)\end{array}$ & $\begin{array}{c}0.0075^{* * *} \\
(0.0016)\end{array}$ & $\begin{array}{c}0.0077^{* * *} \\
(0.0016)\end{array}$ \\
\hline alerts $50 \mathrm{~km}$ & $\begin{array}{l}-0.0012 \\
(0.0021)\end{array}$ & $\begin{array}{l}0.0042^{*} \\
(0.0023)\end{array}$ & $\begin{array}{c}0.0028 \\
(0.0023)\end{array}$ & $\begin{array}{c}0.0037 \\
(0.0023)\end{array}$ & $\begin{array}{l}-0.0005 \\
(0.0023)\end{array}$ & $\begin{array}{l}-0.0004 \\
(0.0023)\end{array}$ \\
\hline alerts $100 \mathrm{~km}$ & $\begin{array}{c}0.0058^{* * *} \\
(0.0020)\end{array}$ & $\begin{array}{c}0.0039 \\
(0.0036)\end{array}$ & $\begin{array}{c}0.0022 \\
(0.0036)\end{array}$ & $\begin{array}{l}0.0064^{*} \\
(0.0036)\end{array}$ & $\begin{array}{c}0.0035 \\
(0.0036)\end{array}$ & $\begin{array}{c}0.0038 \\
(0.0036)\end{array}$ \\
\hline R-squared & 0.0005 & 0.0741 & 0.0744 & 0.1164 & 0.1404 & 0.1405 \\
\hline $\begin{array}{l}\text { number of observations } \\
\text { controls }\end{array}$ & 403,191 & 403,191 & 403,191 & 403,191 & 403,191 & 403,191 \\
\hline municipality & no & yes & yes & yes & yes & yes \\
\hline coordinates (lon, lat, lon $^{2}$, lat ${ }^{2}$, lon*lat) & no & yes & yes & yes & yes & yes \\
\hline weather & no & no & yes & yes & yes & yes \\
\hline satellite visibility & no & no & no & yes & yes & yes \\
\hline baseline accumulated deforestation & no & no & no & no & yes & yes \\
\hline observed conservation policy & no & no & no & no & no & yes \\
\hline
\end{tabular}

Notes: The table reports OLS coefficients for Equation 3-2 (Section 3.3.2). The dependent variable differs across panels: an indicator for secondary vegetation expansion $(\mathrm{d}=1$ if the 2004 through 2014 difference in secondary vegetation coverage $\geq 0.1$ of cell area) in Panel A; non-decreasing secondary vegetation expansion (the 2004 through 2014 difference in non-decreasing secondary vegetation coverage as a share of cell area) in Panel B. Reported independent variables are neighborhood alert intensities (2006 through 2013 total alert area as a share of total neighborhood area). The no/yes markers in bottom rows indicate the inclusion of the following sets of cell-level controls: (i) location: municipality, saturated function of cell longitude/latitude; (ii) weather: average annual temperature, total annual precipitation; (iii) satellite visibility: visual obstructions in satellite imagery in 2004 and 2014; (iv) baseline deforested area: accumulated deforestation through 2003; and $(\mathrm{v})$ observed conservation policy: protected territory status, alert intensity. The cross-sectional sample is built from 2004 through 2014 panel data. It includes all 403,191 Amazon biome cells that contained non-null deforestation through 2003 and at least $50 \%$ primary forest cover in 2004. Standard errors are robust to heteroskedasticity. Significance: ${ }^{* * *} \mathrm{p}<0.01,{ }^{* *} \mathrm{p}<0.05,{ }^{*} \mathrm{p}<0.10$.

the probability of cell-level regeneration expansion by $11 \%$ of the sample mean, and increases the area of secondary vegetation inside the cell by $6 \%$ of the sample mean.

Figure 3.2 provides graphical representations of estimated coefficients for this benchmark specification: sub-figure (a) plots point estimates and the associated 95\% confidence interval for coefficients from Table 3.4, Panel A; sub-figure (b) is analogous for Panel B. The graphs help illustrate that the 
Figure 3.2: Law Enforcement Spillover on Regeneration

(a) $\mathrm{P}(\Delta$ secondary vegetation $\geq 0.1$ cell area $)$

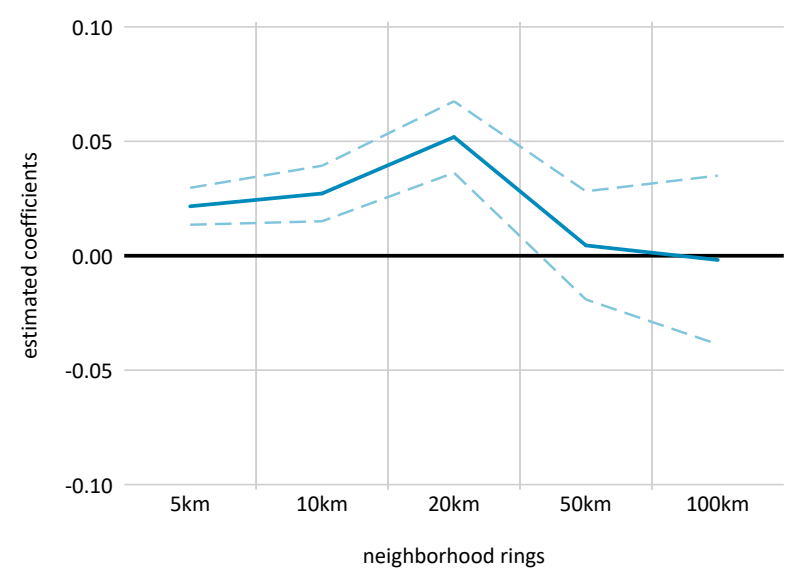

(b) $\Delta$ non-decreasing secondary vegetation (\% cell area)

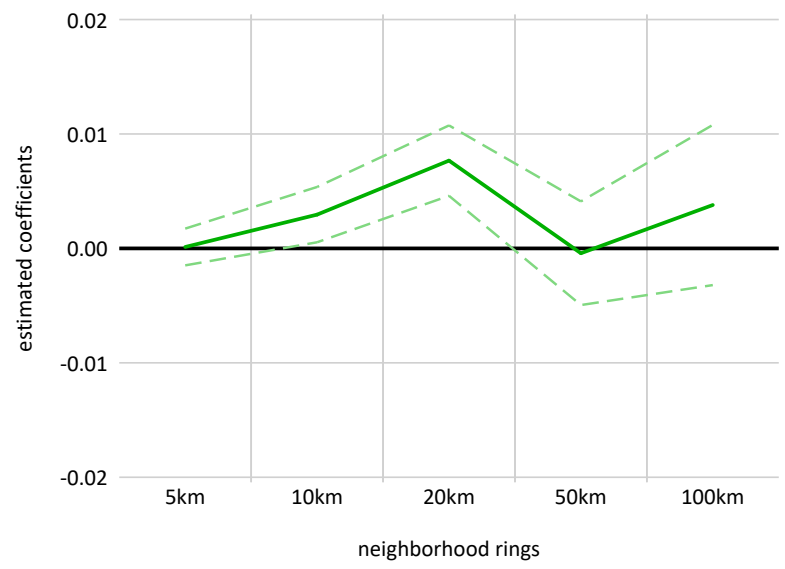

Notes: The graph plots estimated OLS coefficients for the benchmark specification (Table 3.4, column 6). The dependent variable differs across sub-figures: an indicator for secondary vegetation expansion $(\mathrm{d}=1$ if the 2004 through 2014 difference in secondary vegetation coverage $\geq 0.1$ of cell area) in sub-figure (a); nondecreasing secondary vegetation expansion (the 2004 through 2014 difference in non-decreasing secondary vegetation coverage as a share of cell area) in sub-figure (b). The sample includes all 403,191 Amazon biome cells that contained non-null deforestation through 2003 and at least $50 \%$ primary forest cover in 2004. Solid lines indicate point estimates, and dashed lines indicate $95 \%$ confidence intervals.

estimated spillover effects are not linear in distance to law enforcement. For both probability- and area-based dependent variables, the impact grows in magnitude from the smallest $5 \mathrm{~km}$ neighborhood through $20 \mathrm{~km}$, and then drops back to insignificance. This pattern suggests that proximity to recent forest clearing activity might play an important role in tropical regeneration. Regions that are very close to deforestation alerts are probably more exposed to human interference and are thus at greater risk of seeing forest disturbances. Regrowth in these regions is less likely, as captured by the smaller coefficient for the $5 \mathrm{~km}$ neighborhood. As distance to intense clearing activity increases, there is an increase in the probability of seeing secondary vegetation expansion 
and, notably, also an observed increase in the actual area of non-decreasing secondary vegetation. This latter result is particularly important in the sense that it mitigates concerns that probability-based specifications are erroneously capturing an increase in degraded primary forest, which could arguably occur at higher rates near recent forest clearing activity. Although it seems plausible that very close proximity to deforestation hot spots would inhibit regeneration, and that tropical regrowth would gradually increase as abandoned areas are further away from human interference, results do not currently offer an explanation for why this spillover effect suddenly disappears beyond $20 \mathrm{~km}$. This finding merits further empirical investigation, both from the perspective of understanding the underlying spatial dynamics and from that of identifying specificities in the Amazon empirical setting that could explain the observed phenomenon.

Overall, results support the existence of both policy and spatial spillovers. Findings can be interpreted as evidence that the deterrence channel is driving this effect. The presence of stricter enforcement regionally inhibits illegal activity, leading potential offenders to reduce their demand for deforested land. As cleared areas are abandoned, their exposure to human interference decreases, and a natural process of regeneration takes place.

\subsection{2 \\ Robustness: Alternative Dependent Variables and Samples}

Results presented thus far seem consistent with a regional deterrence effect from law enforcement contributing to the abandonment and regeneration of deforested lands. However, as the definition of the benchmark probabilitybased dependent variable and sample are based on set cutoff values, this section tests whether the findings are robust to variations in these thresholds. All robustness specifications reproduce the benchmark specification (Table 3.4, column 6) and always include the full set of controls. Estimated coefficients are reported in both table and plot formats.

To mitigate potential noise in original data, the probability-based dependent variable is built to capture a minimum mass of secondary vegetation expansion. The benchmark cutoff value of $10 \%$ of cell area sets a fairly stringent requirement for minimum regeneration expansion. Figure 3.3 portrays the density histogram for the 2004 through 2014 difference in secondary vegetation extent as a share of cell area, alongside benchmark and robustness cutoff values for dependent variable construction. The histogram shows that this benchmark cutoff successfully excludes much of the minor but still positive - variations in area growth, which would otherwise count 
Figure 3.3: Density Histogram for Difference in Secondary Vegetation Area

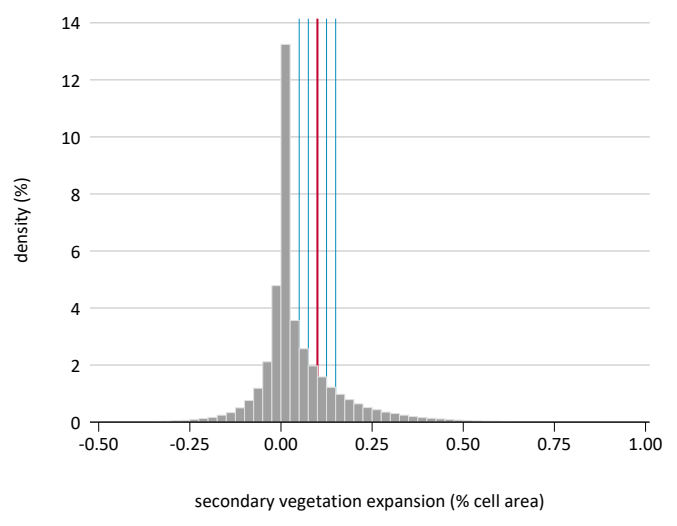

Notes: The figure plots the density histogram for the 2004 through 2014 difference in secondary vegetation extent as a share of cell area. The vertical lines represent the five alternative cutoffs for constructing an indicator that flags whether this difference met a minimum threshold. The bold red line indicates the benchmark threshold of $10 \%$ of cell area; the regular blue lines indicate the different thresholds used in robustness specifications $(5 \%, 7.5 \%, 12.5 \%$, and $15 \%)$.

as actual expansion. The first robustness test uses different cutoff values for defining the probability-based dependent variable. Table 3.5 presents estimated coefficients for cutoff values set at 5\%,7.5\%,10\% (the benchmark threshold), 12.5\%, and 15\%. For ease of comparison, Figure 3.4 plots point estimates and associated $95 \%$ confidence intervals for each of these values. Results are robust across alternative thresholds, with the intensity of law enforcement significantly increasing the probability of cell-level secondary vegetation expansion above these minimum thresholds throughout. The non-linear relationship, with effects increasing through the $20 \mathrm{~km}$ neighborhood and disappearing for larger rings, also remains robust.

The second set of robustness checks restores the dependent variable cutoff to its benchmark value and, instead, explores how results hold across different cutoff values for sample definition. Proximity to remaining primary forest typically favors tropical regrowth (see Section 3.3.2). At the same time, if a cell has seen little deforestation, it actually has a relatively small area upon which secondary forest can grow. Because these effects pull in opposite directions, the benchmark sample comprises cells that had non-null deforestation through 2003 and contained at least 50\% primary forest cover in 2004. Alternative cutoff values for minimum primary forest cover at baseline could potentially capture cells with different predominant effects. The tested values are $10 \%$, 25\%, 50\% (the benchmark threshold), 75\%, and 90\%. Table 3.6 provides descriptive statistics for deforestation and regeneration areas across benchmark and robustness samples, as defined by minimum primary forest area at baseline. 
Table 3.5: Robustness - Alternative Dependent Variables

\begin{tabular}{lccccc}
\hline \hline & $(1)$ & $(2)$ & $(3)$ & $(4)$ & $(5)$ \\
dependent variable cutoff: & $5 \%$ & $7.5 \%$ & $10 \%$ & $12.5 \%$ & $15 \%$ \\
\hline$P(\Delta$ secondary vegetation $\geq$ cell area cutoff value (in column headings) & & \\
& & & & & \\
alerts 5km & $0.0285^{* * *}$ & $0.0280^{* * *}$ & $0.0216^{* * *}$ & $0.0201^{* * *}$ & $0.0167^{* * *}$ \\
& $(0.0047)$ & $(0.0044)$ & $(0.0041)$ & $(0.0038)$ & $(0.0035)$ \\
alerts 10km & $0.0278^{* * *}$ & $0.0253^{* * *}$ & $0.0272^{* * *}$ & $0.0196^{* * *}$ & $0.0216^{* * *}$ \\
& $(0.0071)$ & $(0.0067)$ & $(0.0062)$ & $(0.0057)$ & $(0.0053)$ \\
alerts 20km & $0.0636^{* * *}$ & $0.0612^{* * *}$ & $0.0519^{* * *}$ & $0.0528^{* * *}$ & $0.0419^{* * *}$ \\
& $(0.0091)$ & $(0.0086)$ & $(0.0080)$ & $(0.0074)$ & $(0.0069)$ \\
alerts 50km & 0.0015 & 0.0055 & 0.0045 & -0.0027 & 0.0016 \\
& $(0.0138)$ & $(0.0130)$ & $(0.0121)$ & $(0.0111)$ & $(0.0103)$ \\
alerts 100km & 0.0251 & 0.0151 & -0.0018 & -0.0242 & -0.0115 \\
& $(0.0218)$ & $(0.0204)$ & $(0.0188)$ & $(0.0173)$ & $(0.0158)$ \\
R-squared & & & & & \\
& 0.1163 & 0.1204 & 0.1212 & 0.1185 & 0.1141 \\
& & & & & \\
\hline number of observations & 403,191 & 403,191 & 403,191 & 403,191 & 403,191 \\
controls & & & & & \\
municipality & yes & yes & yes & yes & yes \\
coordinates (lon, lat, lon ${ }^{2}$, lat ${ }^{2}$, lon ${ }^{*}$ lat) $)$ & yes & yes & yes & yes & yes \\
weather & yes & yes & yes & yes & yes \\
satellite visibility & yes & yes & yes & yes & yes \\
baseline accumulated deforestation & yes & yes & yes & yes & yes \\
observed conservation policy & yes & yes & yes & yes & yes \\
\hline \hline
\end{tabular}

Notes: The table reports OLS coefficients for Equation 3-2 (Section 3.3.2). The dependent variable is an indicator for secondary vegetation expansion ( $d=1$ if the 2004 through 2014 difference in secondary vegetation coverage $\geq$ a set cutoff value in terms of cell area). Each column refers to one such cutoff value: $5 \%$ in column $1 ; 7.5 \%$ in column $2 ; 10 \%$ in column 3 (benchmark); $12.5 \%$ in column 4 ; and $15 \%$ in column 5 . Reported independent variables are neighborhood alert intensities (2006 through 2013 total alert area as a share of total neighborhood area). The no/yes markers in bottom rows indicate the inclusion of the following sets of cell-level controls: (i) location: municipality, saturated function of cell longitude/latitude; (ii) weather: average annual temperature, total annual precipitation; (iii) satellite visibility: visual obstructions in satellite imagery in 2004 and 2014; (iv) baseline deforested area: accumulated deforestation through 2003; and (v) observed conservation policy: protected territory status, alert intensity. The cross-sectional sample is built from 2004 through 2014 panel data. It includes all 403,191 Amazon biome cells that contained non-null deforestation through 2003 and at least $50 \%$ primary forest cover in 2004 . Standard errors are robust to heteroskedasticity. Significance: ${ }^{* * *} \mathrm{p}<0.01,{ }^{* *} \mathrm{p}<0.05,{ }^{*} \mathrm{p}<0.10$.

As expected, the lower the minimum primary forest requirement, the more accumulated deforestation the sample has seen.

Table 3.7 presents estimated coefficients across alternative samples for the probability-based dependent variable in Panel A, and the area-based dependent variable in Panel B. Again, Figures 3.5 and 3.6 plot point estimates and associated $95 \%$ confidence intervals for the five alternative cutoff values using probability- and area-based dependent variables, respectively. Results are generally robust across alternative thresholds for both dependent variables. However, as the minimum primary forest area moves towards the extremes of the distribution, there is variation in the shape of the distance-based relationship between law enforcement and regeneration. This points towards important heterogeneity across cells in the baseline sample. At the low end of the distribution for remaining primary forest, cells that held less primary 
Figure 3.4: Robustness - Alternative Dependent Variables

(a) cutoff $=5 \%$

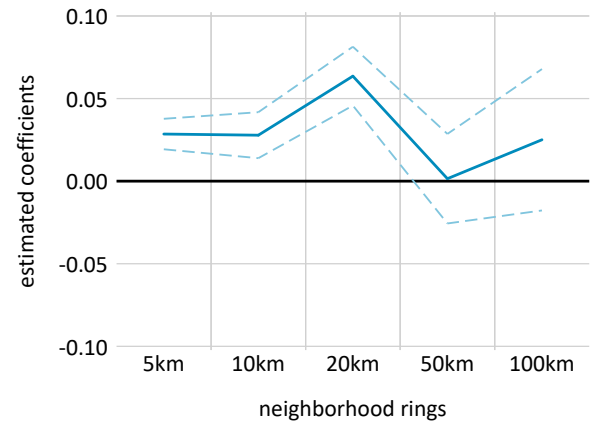

(c) cutoff $=10 \%$

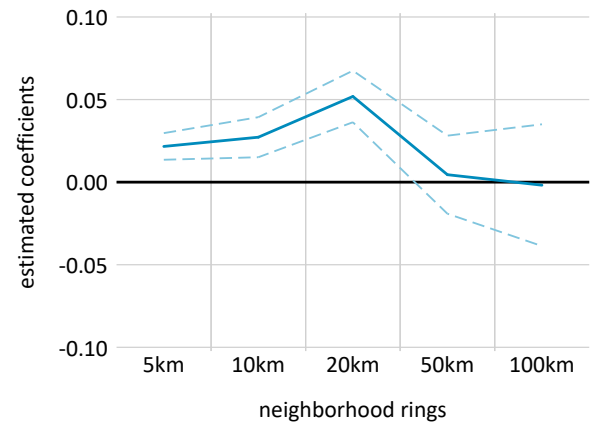

(b) cutoff $=7.5 \%$

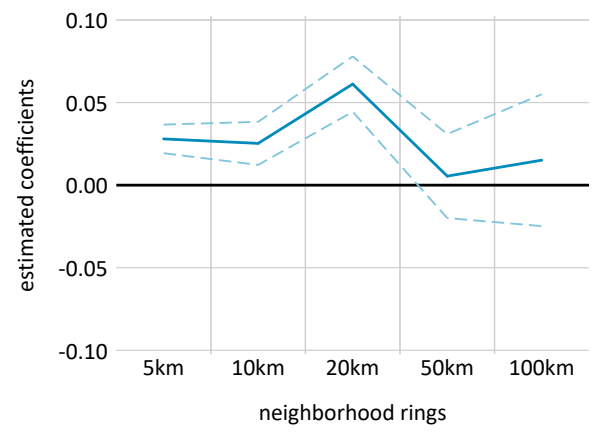

(d) cutoff $=12.5 \%$

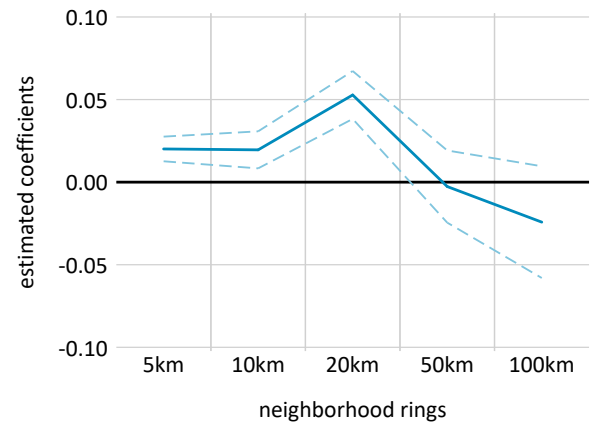

(e) cutoff $=15 \%$

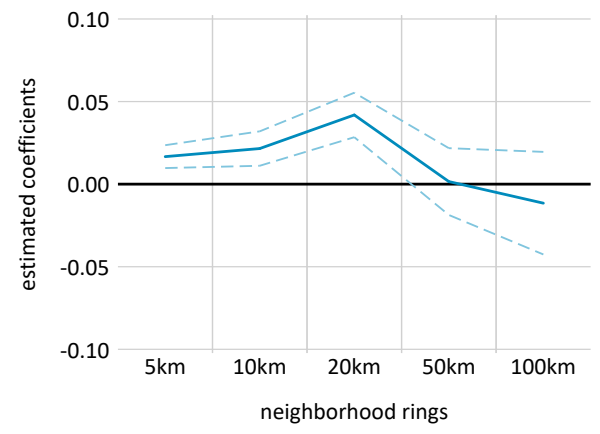

Notes: The graphs plot estimated OLS coefficients for robustness specifications using alternative cutoff values for the probability-based dependent variable (Table 3.5). The dependent variable is an indicator for secondary vegetation expansion $(\mathrm{d}=1$ if the 2004 through 2014 difference in secondary vegetation coverage $\geq$ a set cutoff value in terms of cell area). Each sub-figure refers to one such cutoff value: $5 \%$ in sub-figure (a); $7.5 \%$ in sub-figure (b); $10 \%$ in sub-figure (c) (benchmark); $12.5 \%$ in sub-figure (d); and 15\% in sub-figure (e) The sample includes all 403,191 Amazon biome cells that contained non-null deforestation through 2003 and at least $50 \%$ primary forest cover in 2004. Solid lines indicate point estimates, and dashed lines indicate $95 \%$ confidence intervals.

vegetation at baseline might have seen deforestation at earlier dates and therefore have more consolidated land use in cleared areas. The significantly negative coefficients for law enforcement in the $5 \mathrm{~km}$ neighborhood for samples that include these consolidated areas might indicate that, locally, potential offenders do displace their demand for deforested land to areas containing secondary vegetation. In contrast, at the high end of this distribution, cells 
Table 3.6: Deforestation and Regeneration Across Alternative Samples

\begin{tabular}{lccccc}
\hline \hline & \multicolumn{4}{c}{ baseline primary forest minimum (share cell area) } \\
\cline { 2 - 6 } & $10 \%$ & $25 \%$ & $50 \%$ & $75 \%$ & $90 \%$ \\
\hline raster cell count (900m resolution) & 666,563 & 556,833 & 403,191 & 250,122 & 135,225 \\
& & & & & \\
deforested area, historical through 2003 (ha) & $18,856,377$ & $12,398,219$ & $5,684,454$ & $1,774,051$ & 413,821 \\
2004 secondary vegetation (ha) & $4,828,339$ & $3,595,704$ & $1,995,152$ & 772,163 & 214,229 \\
2004 non-decreasing secondary vegetation (ha) & $2,542,601$ & $1,942,371$ & $1,126,561$ & 463,468 & 135,992 \\
& & & & & \\
deforested area, historical through 2013 (ha) & $26,055,487$ & $18,766,705$ & $10,322,528$ & $4,361,201$ & $1,590,435$ \\
2014 secondary vegetation (ha) & $7,584,578$ & $5,820,556$ & $3,445,083$ & $1,505,182$ & 523,993 \\
2014 non-decreasing secondary vegetation (ha) & $5,245,999$ & $4,045,630$ & $2,399,001$ & $1,037,194$ & 346,579 \\
\hline \hline
\end{tabular}

Notes: The table summarizes deforestation and regeneration areas across alternative samples used in robustness checks. The baseline sample includes all Amazon biome cells that contained non-null deforestation in 2003; alternative samples are further restricted to cells that met a minimum threshold for primary forest cover in 2004 (benchmark cutoff of 50\%).

with very large primary forest cover in 2004 have a higher chance of being located in the agricultural expansion frontier and thus of being intrinsically different in terms of their potential for recent and future clearings. Despite this heterogeneity, the overall patterns of estimated coefficients across alternative samples generally follow the benchmark.

Overall, robustness checks corroborate the interpretation that, when significant, law enforcement has a positive spillover effect on regeneration in near vicinities - at least in areas that have seemingly not experienced advanced consolidation in use of deforested lands.

\subsection{3}

\section{Robustness: Additional Controls}

The benchmark specification includes cell-level controls for location, weather, satellite visibility, baseline deforested area, and observed conservation policy. The set of robustness checks presented in Table 3.8 takes a closer look at controls. It starts by assessing estimated coefficients for the most endogenous set of benchmark controls, observed conservation policy (column 1), and then tests the robustness of results to the inclusion of additional controls that capture the cell's distance (in 100 kilometers) to the following: nearest road (column 2); nearest paved road (column 3); nearest municipality with population $\geq 20,000$ (column 4 ); and nearest waterway (column 5).

Results for the benchmark specification indicate that estimated coefficients for the policy controls flip signs across Table 3.8 panels. While protection reduces and local enforcement increases the probability of secondary vegetation expansion in a cell, they have the opposite effect on the extent of non-decreasing secondary vegetation. This can be explained by the 
Table 3.7: Robustness - Alternative Samples

\begin{tabular}{|c|c|c|c|c|c|}
\hline sample selection cutoff: & $\begin{array}{c}(1) \\
10 \%\end{array}$ & $\begin{array}{c}(2) \\
25 \%\end{array}$ & $\begin{array}{c}(3) \\
50 \%\end{array}$ & $\begin{array}{c}(4) \\
75 \%\end{array}$ & $\begin{array}{c}(5) \\
90 \%\end{array}$ \\
\hline \multicolumn{6}{|c|}{ Panel $A: P(\Delta$ secondary vegetation $\geq 0.1$ cell area $)$} \\
\hline alerts $5 \mathrm{~km}$ & $\begin{array}{c}0.0039 \\
(0.0033)\end{array}$ & $\begin{array}{c}0.0109^{* * *} \\
(0.0036)\end{array}$ & $\begin{array}{c}0.0216^{* * *} \\
(0.0041)\end{array}$ & $\begin{array}{c}0.0384^{* * *} \\
(0.0050)\end{array}$ & $\begin{array}{c}0.0591^{* * *} \\
(0.0064)\end{array}$ \\
\hline alerts $10 \mathrm{~km}$ & $\begin{array}{c}0.0214^{* * *} \\
(0.0050)\end{array}$ & $\begin{array}{c}0.0211^{* * *} \\
(0.0054)\end{array}$ & $\begin{array}{c}0.0272^{* * *} \\
(0.0062)\end{array}$ & $\begin{array}{c}0.0225^{* * *} \\
(0.0074)\end{array}$ & $\begin{array}{c}0.0158^{*} \\
(0.0092)\end{array}$ \\
\hline alerts $20 \mathrm{~km}$ & $\begin{array}{c}0.0434^{* * *} \\
(0.0064)\end{array}$ & $\begin{array}{c}0.0487^{* * *} \\
(0.0070)\end{array}$ & $\begin{array}{c}0.0519^{* * *} \\
(0.0080)\end{array}$ & $\begin{array}{c}0.0617^{* * *} \\
(0.0095)\end{array}$ & $\begin{array}{c}0.0572^{* * *} \\
(0.0116)\end{array}$ \\
\hline alerts $50 \mathrm{~km}$ & $\begin{array}{l}-0.0089 \\
(0.0099)\end{array}$ & $\begin{array}{c}-0.0067 \\
(0.0106)\end{array}$ & $\begin{array}{c}0.0045 \\
(0.0121)\end{array}$ & $\begin{array}{c}0.0084 \\
(0.0141)\end{array}$ & $\begin{array}{c}0.0198 \\
(0.0170)\end{array}$ \\
\hline alerts $100 \mathrm{~km}$ & $\begin{array}{l}0.0287^{*} \\
(0.0157)\end{array}$ & $\begin{array}{c}0.0244 \\
(0.0168)\end{array}$ & $\begin{array}{c}-0.0018 \\
(0.0188)\end{array}$ & $\begin{array}{l}-0.0215 \\
(0.0214)\end{array}$ & $\begin{array}{c}-0.0600^{* *} \\
(0.0242)\end{array}$ \\
\hline R-squared & 0.1140 & 0.1184 & 0.1212 & 0.1130 & 0.0924 \\
\hline \multicolumn{6}{|c|}{ Panel B: $\Delta$ non-decreasing secondary vegetation ( $\%$ cell area) } \\
\hline alerts $5 \mathrm{~km}$ & $\begin{array}{c}-0.0041^{* * *} \\
(0.0007)\end{array}$ & $\begin{array}{c}-0.0030^{* * * *} \\
(0.0007)\end{array}$ & $\begin{array}{c}0.0001 \\
(0.0008)\end{array}$ & $\begin{array}{c}0.0046^{* * *} \\
(0.0010)\end{array}$ & $\begin{array}{c}0.0069^{* * *} \\
(0.0013)\end{array}$ \\
\hline alerts $10 \mathrm{~km}$ & $\begin{array}{c}0.0039^{* * *} \\
(0.0011)\end{array}$ & $\begin{array}{c}0.0033^{* * *} \\
(0.0011)\end{array}$ & $\begin{array}{c}0.0030^{* *} \\
(0.0012)\end{array}$ & $\begin{array}{c}0.0004 \\
(0.0015)\end{array}$ & $\begin{array}{c}-0.0002 \\
(0.0019)\end{array}$ \\
\hline alerts $20 \mathrm{~km}$ & $\begin{array}{c}0.0072^{\text {*** }} \\
(0.0014)\end{array}$ & $\begin{array}{c}0.0078^{* * *} \\
(0.0015)\end{array}$ & $\begin{array}{c}0.0077^{* * *} \\
(0.0016)\end{array}$ & $\begin{array}{c}0.0079^{* * *} \\
(0.0018)\end{array}$ & $\begin{array}{c}0.0064^{* * *} \\
(0.0024)\end{array}$ \\
\hline alerts $50 \mathrm{~km}$ & $\begin{array}{c}-0.0041^{*} \\
(0.0021)\end{array}$ & $\begin{array}{c}-0.0028 \\
(0.0022)\end{array}$ & $\begin{array}{l}-0.0004 \\
(0.0023)\end{array}$ & $\begin{array}{c}0.0006 \\
(0.0026)\end{array}$ & $\begin{array}{c}0.0023 \\
(0.0033)\end{array}$ \\
\hline alerts $100 \mathrm{~km}$ & $\begin{array}{c}0.0079^{* *} \\
(0.0033)\end{array}$ & $\begin{array}{l}0.0064^{*} \\
(0.0034)\end{array}$ & $\begin{array}{c}0.0038 \\
(0.0036)\end{array}$ & $\begin{array}{c}0.0017 \\
(0.0039)\end{array}$ & $\begin{array}{c}-0.0036 \\
(0.0048)\end{array}$ \\
\hline R-squared & 0.1529 & 0.1534 & 0.1405 & 0.1092 & 0.0828 \\
\hline $\begin{array}{l}\text { number of observations } \\
\text { controls }\end{array}$ & 666,563 & 556,833 & 403,191 & 250,122 & 135,225 \\
\hline municipality & yes & yes & yes & yes & yes \\
\hline coordinates (lon, lat, $\operatorname{lon}^{2}$, lat $^{2}$, lon*lat) & yes & yes & yes & yes & yes \\
\hline weather & yes & yes & yes & yes & yes \\
\hline satellite visibility & yes & yes & yes & yes & yes \\
\hline baseline accumulated deforestation & yes & yes & yes & yes & yes \\
\hline observed conservation policy & yes & yes & yes & yes & yes \\
\hline
\end{tabular}

Notes: The table reports OLS coefficients for Equation 3-2 (Section 3.3.2). The dependent variable differs across panels: an indicator for secondary vegetation expansion $(\mathrm{d}=1$ if the 2004 through 2014 difference in secondary vegetation coverage $\geq 0.1$ of cell area) in Panel A; non-decreasing secondary vegetation expansion (the 2004 through 2014 difference in non-decreasing secondary vegetation coverage as a share of cell area) in Panel B. The spatial samples are defined as Amazon biome cells that contained non-null deforestation through 2003 and met a minimum cutoff value for primary forest cover in 2004. Each column refers to one such cutoff value: $10 \%$ in column $1 ; 25 \%$ in column $2 ; 50 \%$ in column 3 (benchmark); $75 \%$ in column 4 ; and $90 \%$ in column 5 . Reported independent variables are neighborhood alert intensities (2006 through 2013 total alert area as a share of total neighborhood area). The no/yes markers in bottom rows indicate the inclusion of the following sets of cell-level controls: (i) location: municipality, saturated function of cell longitude/latitude; (ii) weather: average annual temperature, total annual precipitation; (iii) satellite visibility: visual obstructions in satellite imagery in 2004 and 2014; (iv) baseline deforested area: accumulated deforestation through 2003; and (v) observed conservation policy: protected territory status, alert intensity. The cross-sectional sample is built from 2004 through 2014 panel data. Standard errors are robust to heteroskedasticity. Significance: ${ }^{* * *} \mathrm{p}<0.01,{ }^{* *} \mathrm{p}<0.05,{ }^{*} \mathrm{p}<0.10$. 
Figure 3.5: Robustness - Alternative Samples, Probability-Based Outcome

(a) cutoff $=10 \%$

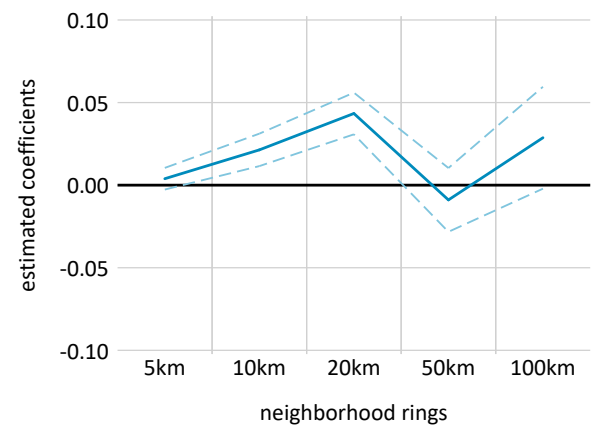

(c) cutoff $=50 \%$

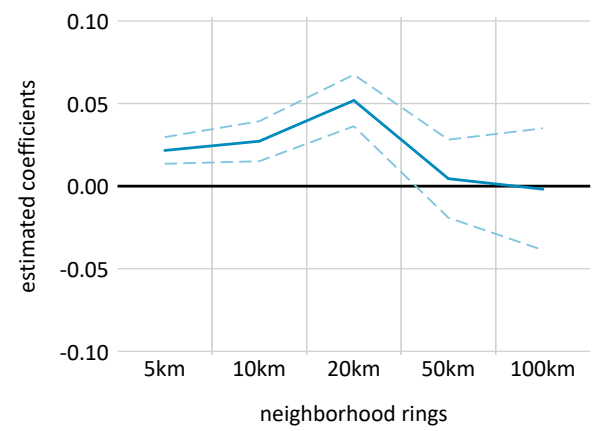

(b) cutoff $=25 \%$

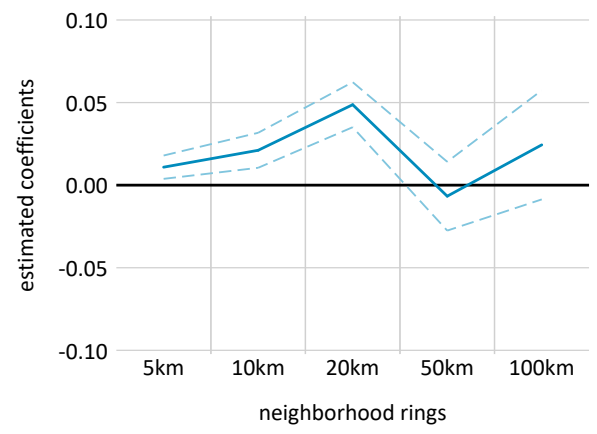

(d) cutoff $=75 \%$

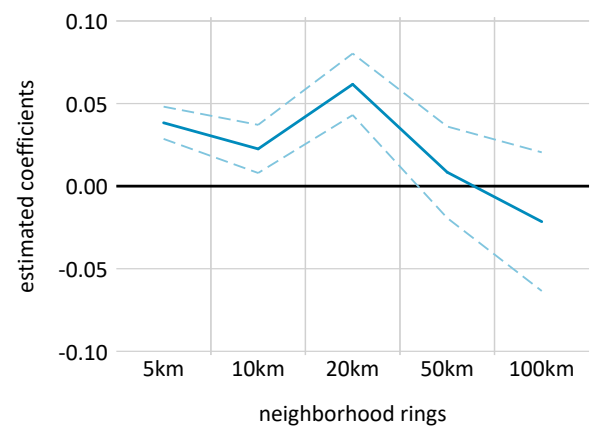

(e) cutoff $=90 \%$

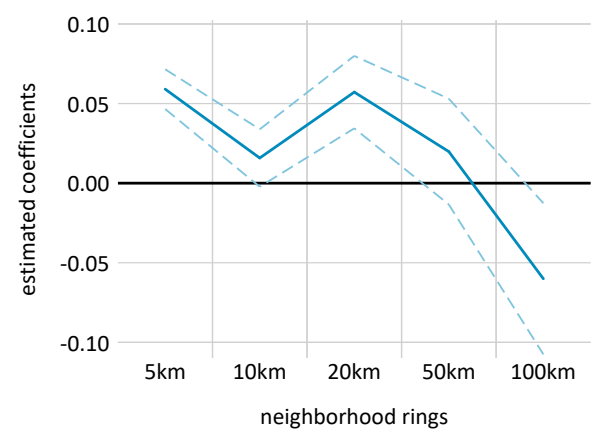

Notes: The graphs plot estimated OLS coefficients for robustness specifications using alternative cutoff values for sample definition (Table 3.7, Panel A). The dependent variable is an indicator for secondary vegetation expansion ( $\mathrm{d}=1$ if the 2004 through 2014 difference in secondary vegetation coverage $\geq 0.1$ of cell area). The samples are defined as Amazon biome cells that contained non-null deforestation through 2003 and met a minimum cutoff value for primary forest cover in 2004. Each sub-figure refers to one such cutoff value: $10 \%$ in sub-figure (a); $25 \%$ in sub-figure (b); $50 \%$ in sub-figure (c) (benchmark); $75 \%$ in sub-figure (d); and 90\% in sub-figure (e). Solid lines indicate point estimates, and dashed lines indicate $95 \%$ confidence intervals.

inherent difference between these two outcome variables. As the probability-based dependent variable does not distinguish between remaining primary vegetation and actual secondary vegetation (see Section 3.3.2), estimated coefficients might mix effects that pull in opposite directions protection is expected to increase regeneration, but decrease degradation and deforestation; greater alert intensity inside a cell indicates more intense 
Figure 3.6: Robustness - Alternative Samples, Area-Based Outcome

(a) cutoff $=10 \%$

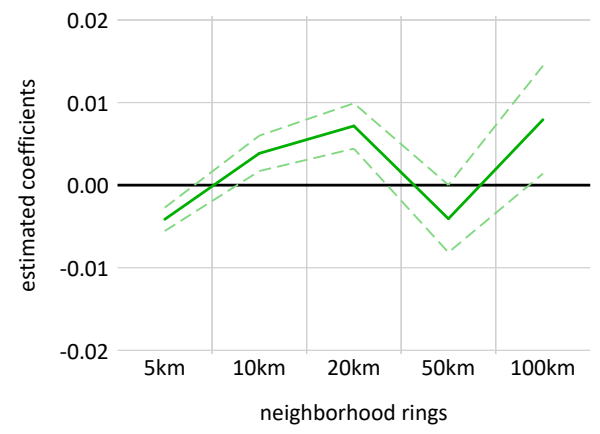

(c) cutoff $=50 \%$

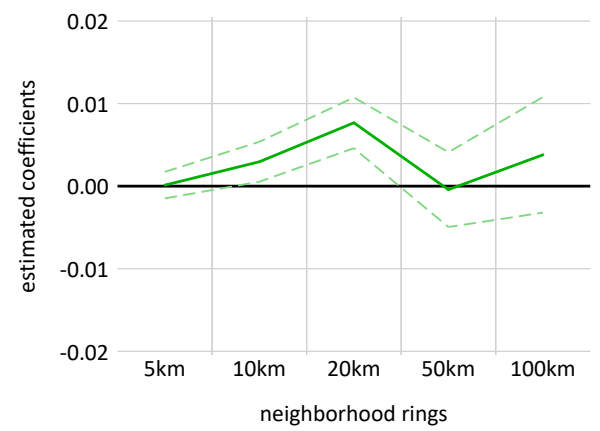

(b) cutoff $=25 \%$

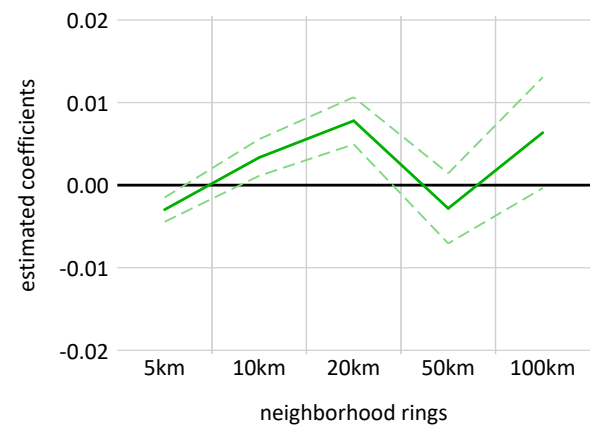

(d) cutoff $=75 \%$

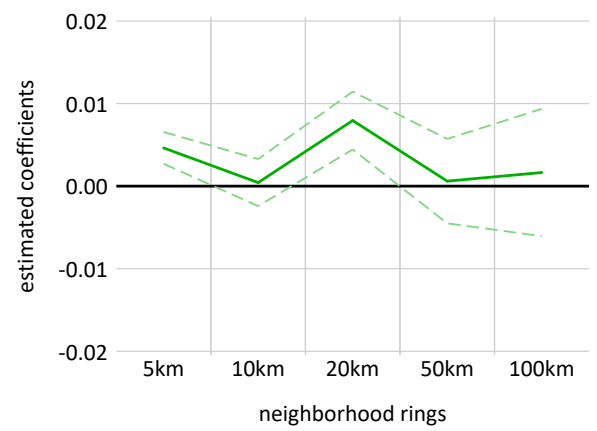

(e) cutoff $=90 \%$

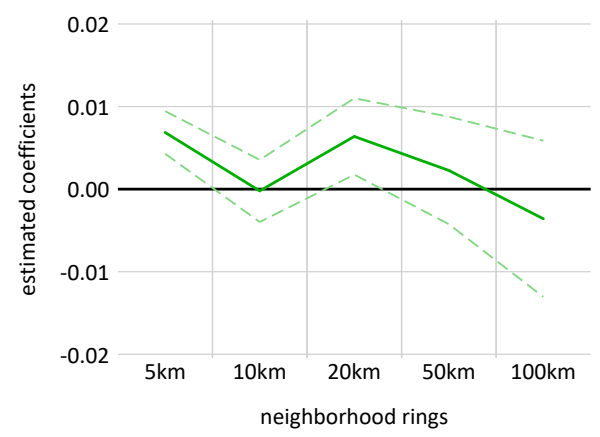

Notes: The graphs plot estimated OLS coefficients for robustness specifications using alternative cutoff values for sample definition (Table 3.7, Panel B). The dependent variable is non-decreasing secondary vegetation expansion (the 2004 through 2014 difference in non-decreasing secondary vegetation coverage as a share of cell area). The samples are defined as Amazon biome cells that contained non-null deforestation through 2003 and met a minimum cutoff value for primary forest cover in 2004. Each sub-figure refers to one such cutoff value: $10 \%$ in sub-figure (a); $25 \%$ in sub-figure (b); $50 \%$ in sub-figure (c) (benchmark); $75 \%$ in subfigure (d); and $90 \%$ in sub-figure (e). Solid lines indicate point estimates, and dashed lines indicate $95 \%$ confidence intervals.

clearing activity at the local level, which is expected to limit regrowth capacity but also capture a greater risk of degradation and deforestation. Interpreting these coefficients for the probability-based dependent variable can therefore be misleading. Thus, results for the area-based dependent variable are expected to more accurately capture the impact of these conservation policies on regeneration. Indeed, coefficients for protection are 
positive, although insignificant, and those for alert intensity are negative. This reinforces the idea that isolation favors regeneration, and that close proximity to deforestation activity significantly curbs regeneration.

The remaining columns of Table 3.8 include controls for the cell's distance to transport infrastructure, more populated municipalities, or waterways. Each of these could be interpreted as a measure of the cell's exposure to human interference. Estimated coefficients for neighborhood enforcement remain highly stable in magnitude and significance across specifications for both dependent variables. These findings lend further support to the benchmark specification, whose results do not appear to be driven by omitted variables.

\subsection{4}

\section{Counterfactual Exercises: Monitoring Capacity}

The evidence shows that regional law enforcement significantly promoted regeneration at the cell level. Yet, interpreting the magnitude of this effect when looking at a raster cell is not straightforward. To shed light on how these effects map onto aggregate sample impacts, if at all, this section presents two counterfactual exercises. In each exercise, the benchmark specification (Table 3.4, column 6) is re-estimated under a different hypothetical scenario, and the total variation in non-decreasing secondary vegetation is calculated by adding area outcomes across sample cells. Instead of looking at two outcomes of interest, as in the regression analyses, counterfactual exercises are restricted to areas of non-decreasing secondary vegetation. This implies that counterfactual estimates are conservative to the extent that they only account for variation in a subset of observed regeneration.

The first counterfactual scenario builds on the idea of enhanced monitoring of forest clearing activity. Satellite-based measuring (PRODES) and monitoring (DETER) systems have different spatial resolutions (see Appendices B.1.1 and B.1.2). While DETER provides high-frequency information with low resolution, PRODES only generates annual data but at higher resolution. Thus, it is to be expected that the detected areas of forest disturbance differ across systems, with PRODES systematically recording a larger total area of forest loss. ${ }^{12}$ Table 3.9 shows that this was, in fact, the case. Despite large variability across years (likely due to variation in satellite

\footnotetext{
${ }^{12}$ Another potential source of difference in observed areas across systems is that PRODES only detects clear-cut deforestation, while DETER is capable of detecting forest degradation. In isolation, this could result in a larger observed area of disturbance via DETER. However, this potential advantage is likely undermined by DETER's significantly poorer resolution during the sample period, DETER could only detect disturbances larger than 25ha, while PRODES detected clearings larger than 6.25ha.
} 
Table 3.8: Robustness - Additional Controls

\begin{tabular}{|c|c|c|c|c|c|}
\hline & $\begin{array}{c}(1) \\
\text { benchmark }\end{array}$ & $\begin{array}{c}(2) \\
\text { all roads }\end{array}$ & $\begin{array}{c}(3) \\
\text { paved roads }\end{array}$ & $\begin{array}{c}(4) \\
\text { large pop }\end{array}$ & $\begin{array}{c}(5) \\
\text { water }\end{array}$ \\
\hline \multicolumn{6}{|c|}{ Panel A: P(secondary vegetation expansion $>=10 \%$ of cell area $)$} \\
\hline alerts $5 \mathrm{~km}$ & $\begin{array}{c}0.0216^{* * *} \\
(0.0041)\end{array}$ & $\begin{array}{c}0.0218^{* * *} \\
(0.0041)\end{array}$ & $\begin{array}{c}0.0220^{* * *} \\
(0.0041)\end{array}$ & $\begin{array}{c}0.0216^{* * *} \\
(0.0041)\end{array}$ & $\begin{array}{c}0.0224 * * * \\
(0.0041)\end{array}$ \\
\hline alerts $10 \mathrm{~km}$ & $\begin{array}{c}0.0272^{* * *} \\
(0.0062)\end{array}$ & $\begin{array}{c}0.0276^{* * *} \\
(0.0062)\end{array}$ & $\begin{array}{c}0.0276^{* * *} \\
(0.0062)\end{array}$ & $\begin{array}{c}0.0272^{* * *} \\
(0.0062)\end{array}$ & $\begin{array}{c}0.0284^{* * *} * \\
(0.0062)\end{array}$ \\
\hline alerts $20 \mathrm{~km}$ & $\begin{array}{c}0.0519^{* * *} * \\
(0.0080)\end{array}$ & $\begin{array}{c}0.0523^{* * *} \\
(0.0080)\end{array}$ & $\begin{array}{c}0.0521^{* * *} \\
(0.0080)\end{array}$ & $\begin{array}{c}0.0519^{* * *} \\
(0.0080)\end{array}$ & $\begin{array}{c}0.0568^{* * * *} \\
(0.0080)\end{array}$ \\
\hline alerts $50 \mathrm{~km}$ & $\begin{array}{c}0.0045 \\
(0.0121)\end{array}$ & $\begin{array}{c}0.0004 \\
(0.0121)\end{array}$ & $\begin{array}{c}0.0014 \\
(0.0121)\end{array}$ & $\begin{array}{c}0.0049 \\
(0.0121)\end{array}$ & $\begin{array}{c}0.0057 \\
(0.0121)\end{array}$ \\
\hline alerts $100 \mathrm{~km}$ & $\begin{array}{l}-0.0018 \\
(0.0188)\end{array}$ & $\begin{array}{l}-0.0119 \\
(0.0189)\end{array}$ & $\begin{array}{l}-0.0132 \\
(0.0190)\end{array}$ & $\begin{array}{l}-0.0020 \\
(0.0188)\end{array}$ & $\begin{array}{c}0.0021 \\
(0.0188)\end{array}$ \\
\hline $\mathrm{d}=1$ if protected & $\begin{array}{c}-0.0086^{* * *} \\
(0.0018)\end{array}$ & $\begin{array}{c}-0.0070^{* * * *} \\
(0.0019)\end{array}$ & $\begin{array}{c}-0.0063^{* * *} \\
(0.0019)\end{array}$ & $\begin{array}{c}-0.0085^{* * * *} \\
(0.0018)\end{array}$ & $\begin{array}{c}-0.0066^{* * *} \\
(0.0018)\end{array}$ \\
\hline alert intensity & $\begin{array}{c}0.0041^{* * *} * \\
(0.0015)\end{array}$ & $\begin{array}{c}0.0040^{* * *} \\
(0.0015)\end{array}$ & $\begin{array}{c}0.0041^{* * *} \\
(0.0015)\end{array}$ & $\begin{array}{c}0.0041^{* * *} \\
(0.0015)\end{array}$ & $\begin{array}{c}0.0040^{* * *} \\
(0.0015)\end{array}$ \\
\hline distance to header variable & & $\begin{array}{c}-0.0131^{* * *} \\
(0.0022)\end{array}$ & $\begin{array}{c}-0.0105^{* * *} \\
(0.0015)\end{array}$ & $\begin{array}{l}-0.0070 \\
(0.0044)\end{array}$ & $\begin{array}{c}-0.0352^{* * *} \\
(0.0024)\end{array}$ \\
\hline R-squared & 0.1212 & 0.1213 & 0.1213 & 0.1212 & 0.1217 \\
\hline \multicolumn{6}{|c|}{ Panel B: non-decreasing secondary vegetation expansion (cell share) } \\
\hline alerts $5 \mathrm{~km}$ & $\begin{array}{c}0.0001 \\
(0.0008)\end{array}$ & $\begin{array}{c}0.0002 \\
(0.0008)\end{array}$ & $\begin{array}{c}0.0002 \\
(0.0008)\end{array}$ & $\begin{array}{c}0.0001 \\
(0.0008)\end{array}$ & $\begin{array}{c}0.0002 \\
(0.0008)\end{array}$ \\
\hline alerts $10 \mathrm{~km}$ & $\begin{array}{c}0.0030^{* *} \\
(0.0012)\end{array}$ & $\begin{array}{c}0.0030^{* *} \\
(0.0012)\end{array}$ & $\begin{array}{c}0.0030^{* *} \\
(0.0012)\end{array}$ & $\begin{array}{c}0.0030^{* *} \\
(0.0012)\end{array}$ & $\begin{array}{c}0.0031^{* *} \\
(0.0012)\end{array}$ \\
\hline alerts $20 \mathrm{~km}$ & $\begin{array}{c}0.0077^{* * *} \\
(0.0016)\end{array}$ & $\begin{array}{c}0.0078^{* * *} \\
(0.0016)\end{array}$ & $\begin{array}{c}0.0077^{* * * *} \\
(0.0016)\end{array}$ & $\begin{array}{c}0.0077^{* * *} \\
(0.0016)\end{array}$ & $\begin{array}{c}0.0084^{* * *} \\
(0.0016)\end{array}$ \\
\hline alerts $50 \mathrm{~km}$ & $\begin{array}{c}-0.0004 \\
(0.0023)\end{array}$ & $\begin{array}{c}-0.0014 \\
(0.0023)\end{array}$ & $\begin{array}{c}-0.0009 \\
(0.0023)\end{array}$ & $\begin{array}{c}-0.0004 \\
(0.0023)\end{array}$ & $\begin{array}{l}-0.0002 \\
(0.0023)\end{array}$ \\
\hline alerts $100 \mathrm{~km}$ & $\begin{array}{c}0.0038 \\
(0.0036)\end{array}$ & $\begin{array}{c}0.0014 \\
(0.0036)\end{array}$ & $\begin{array}{c}0.0019 \\
(0.0036)\end{array}$ & $\begin{array}{c}0.0038 \\
(0.0036)\end{array}$ & $\begin{array}{c}0.0044 \\
(0.0036)\end{array}$ \\
\hline $\mathrm{d}=1$ if protected & $\begin{array}{c}0.0002 \\
(0.0003)\end{array}$ & $\begin{array}{c}0.0006 \\
(0.0004)\end{array}$ & $\begin{array}{c}0.0006 \\
(0.0004)\end{array}$ & $\begin{array}{c}0.0002 \\
(0.0003)\end{array}$ & $\begin{array}{c}0.0005 \\
(0.0004)\end{array}$ \\
\hline alert intensity & $\begin{array}{c}-0.0015^{* * *} \\
(0.0003)\end{array}$ & $\begin{array}{c}-0.0015^{* * *} \\
(0.0003)\end{array}$ & $\begin{array}{c}-0.0015^{* * *} \\
(0.0003)\end{array}$ & $\begin{array}{c}-0.0015^{* * *} \\
(0.0003)\end{array}$ & $\begin{array}{c}-0.0015^{* * *} \\
(0.0003)\end{array}$ \\
\hline distance to header variable & & $\begin{array}{c}-0.0031^{* * *} \\
(0.0004)\end{array}$ & $\begin{array}{c}-0.0018^{* * *} \\
(0.0003)\end{array}$ & $\begin{array}{c}0.0002 \\
(0.0009)\end{array}$ & $\begin{array}{c}-0.0054^{* * *} \\
(0.0005)\end{array}$ \\
\hline R-squared & 0.1405 & 0.1405 & 0.1405 & 0.1405 & 0.1407 \\
\hline $\begin{array}{l}\text { number of observations } \\
\text { controls }\end{array}$ & 403,191 & 403,191 & 403,191 & 403,191 & 403,191 \\
\hline municipality & yes & yes & yes & yes & yes \\
\hline coordinates (lon, lat, lon $^{2}$, lat $^{2}$, lon*lat $^{*}$ & yes & yes & yes & yes & yes \\
\hline weather & yes & yes & yes & yes & yes \\
\hline satellite visibility & yes & yes & yes & yes & yes \\
\hline baseline accumulated deforestation & yes & yes & yes & yes & yes \\
\hline
\end{tabular}

Notes: The table reports OLS coefficients for Equation 3-2 (Section 3.3.2). The dependent variable differs across panels: an indicator for secondary vegetation expansion $(\mathrm{d}=1$ if the 2004 through 2014 difference in secondary vegetation coverage $\geq 0.1$ of cell area) in Panel A; non-decreasing secondary vegetation expansion (the 2004 through 2014 difference in non-decreasing secondary vegetation coverage as a share of cell area) in Panel B. Reported independent variables are neighborhood alert intensities (2006 through 2013 total alert area as a share of total neighborhood area) and select controls. The benchmark specification (column 1) reproduces that of Table 3.4, column 6, but with reported coefficients for observed policy controls. Additional controls capture distance (in 100 kilometers) to the following: nearest road (column 2); nearest paved road (column 3); nearest municipality with population $\geq 20,000$ (column 4); and nearest waterway (column 5), as indicated in column headers. The no/yes markers in bottom rows indicate the inclusion of the following sets of cell-level controls: (i) location: municipality, saturated function of cell longitude/latitude; (ii) weather: average annual temperature, total annual precipitation; (iii) satellite visibility: visual obstructions in satellite imagery in 2004 and 2014; and (iv) baseline deforested area: accumulated deforestation through 2003. The cross-sectional sample is built from 2004 through 2014 panel data. It includes all 403,191 Amazon biome cells that contained non-null deforestation through 2003 and at least 50\% primary forest cover in 2004. Standard errors are robust to heteroskedasticity. Significance: ${ }^{* *} \mathrm{p}<0.01,{ }^{* *} \mathrm{p}<0.05,{ }^{*} \mathrm{p}<0.10$. 
Table 3.9: Recorded Areas in Monitoring and Measuring Systems

\begin{tabular}{cccc}
\hline \hline year & $\begin{array}{c}\text { detected area } \\
\text { DETER (ha) }\end{array}$ & $\begin{array}{c}\text { detected area } \\
\text { PRODES (ha) }\end{array}$ & $\begin{array}{c}\text { detection share } \\
\text { DETER/PRODES }\end{array}$ \\
\hline 2006 & 491,457 & $1,091,857$ & $45 \%$ \\
2007 & 816,888 & $1,150,637$ & $71 \%$ \\
2008 & 438,735 & $1,336,129$ & $33 \%$ \\
2009 & 224,019 & 643,061 & $35 \%$ \\
2010 & 266,439 & 635,751 & $42 \%$ \\
2011 & 204,710 & 574,122 & $36 \%$ \\
2012 & 277,758 & 446,873 & $62 \%$ \\
2013 & 305,376 & 542,452 & $56 \%$ \\
\hline total & $\mathbf{3 , 0 2 5 , 3 8 0}$ & $\mathbf{6 , 4 2 0 , 8 8 2}$ & $\mathbf{4 7 \%}$ \\
\hline \hline
\end{tabular}

Notes: The table presents total area recorded for the Brazilian Legal Amazon in deforestation monitoring (DETER) and measuring (PRODES) systems, as well as the ratio between these areas.

visibility), the area recorded as DETER alerts is, on average, less than half that of PRODES. In light of this, the first hypothetical scenario boosts the monitoring system by allowing it to detect every deforestation patch detected in the measuring system. In practice, this means that every $900 \mathrm{~m}$ raster cell that had held non-null PRODES deforestation increment from 2006 through 2013 also held a DETER deforestation alert. ${ }^{13}$

Figure $3.7 \mathrm{a}$ plots the difference in the total area of non-decreasing secondary vegetation in counterfactual and observed scenarios. Each data point in the graph refers to a different sample, as defined by the minimum baseline primary forest cover. Counterfactual totals are systematically positive across samples, indicating that enhanced monitoring would have increased the area of non-decreasing secondary vegetation in the Amazon. For the benchmark sample, this increase totals about 280 thousand hectares and is statistically significant. Samples with lower thresholds for primary forest have roughly equal point estimates, but larger confidence intervals. This suggests that the cells with greater primary forest cover at baseline in these samples are driving the results. This finding appears to be aligned with the discussion that greater sample heterogeneity contributes to greater variability in outcomes under less stringent minimum primary forest requirements. As these requirements increase, the counterfactual point estimate decreases in size, although it remains substantial. To better contextualize this magnitude, Figures $3.7 \mathrm{~b}$ and $3.7 \mathrm{c}$ present counterfactual area differences as shares of observed deforested and regenerated areas,

\footnotetext{
${ }^{13} \mathrm{PRODES}$ deforestation increment raster data is at the $30 \mathrm{~m}$ resolution, such that the non-null deforestation increment is based on the presence of deforestation minicells.
} 
Figure 3.7: Counterfactual Exercise - Enhanced Monitoring System

(a) absolute area

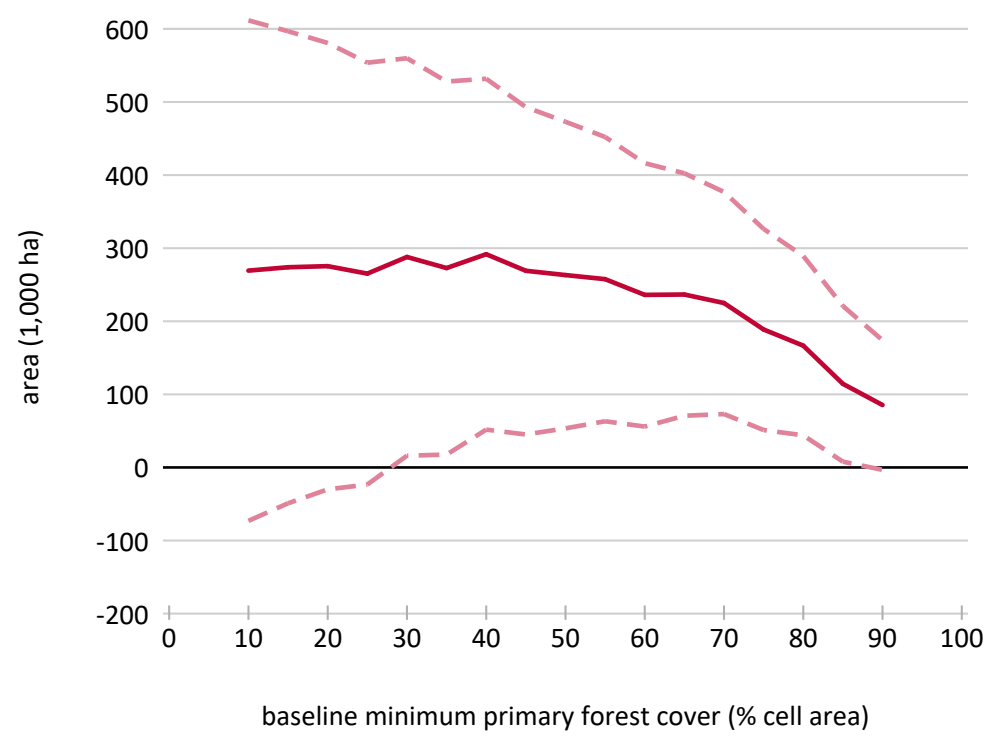

(b) as share of deforested area

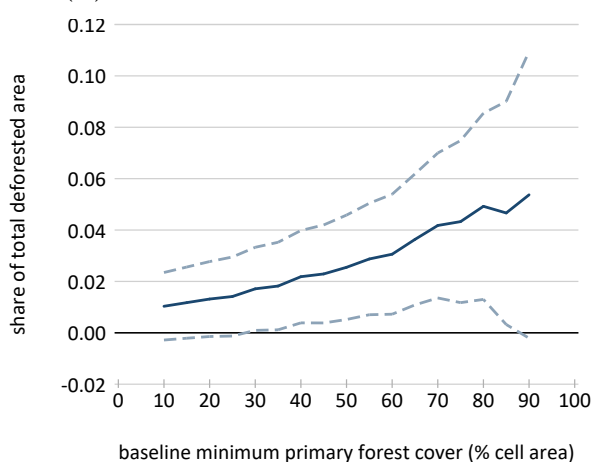

(c) as share of regenerated area

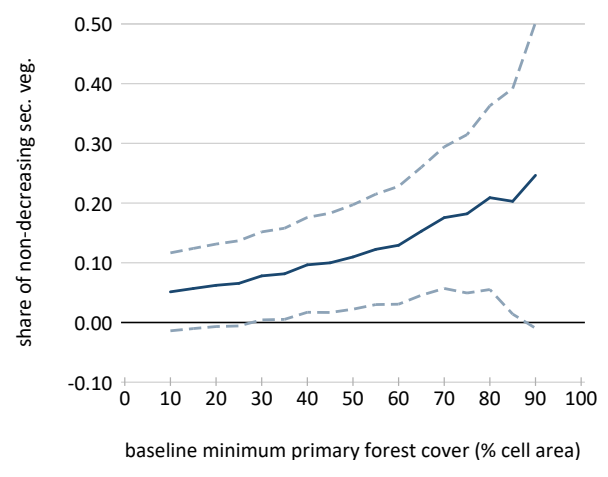

Notes: The figure illustrates the difference in total area of non-decreasing secondary vegetation in the counterfactual and observed scenarios. The counterfactual is a hypothetical scenario in which the deforestation monitoring system detected and issued alerts for all forest clearings that were recorded in the deforestation measuring system (2006 through 2013 increment). Alternative samples, plotted along the horizontal axis, are defined as Amazon biome cells that contained non-null deforestation through 2003 and met a minimum cutoff (axis) value defined in terms of primary forest cover in 2004. Solid lines indicate counterfactual estimates, and dashed lines indicate $95 \%$ confidence intervals. Results are shown as: total sample area in sub-figure (a); share of observed 2014 sample deforestation in sub-figure (b); and share of observed 2014 sample regeneration, as captured by the extent of non-decreasing secondary vegetation, in sub-figure (c). Counterfactual scenarios are built using results from the benchmark specification (Table 3.4, column 6) and setting the alert area equal to the observed deforested area (see Table 3.9).

respectively. Under the hypothetically enhanced monitoring system, non-decreasing secondary vegetation in the benchmark sample would have expanded over an additional 3\% of total deforested area. This represents growth of more than $10 \%$ of recorded non-decreasing secondary vegetation area. For samples with greater minimum primary forest areas, these shares increase substantially, but so do confidence intervals.

This exercise is particularly informative considering that Brazil recently 
Figure 3.8: Counterfactual Exercise - No Monitoring System

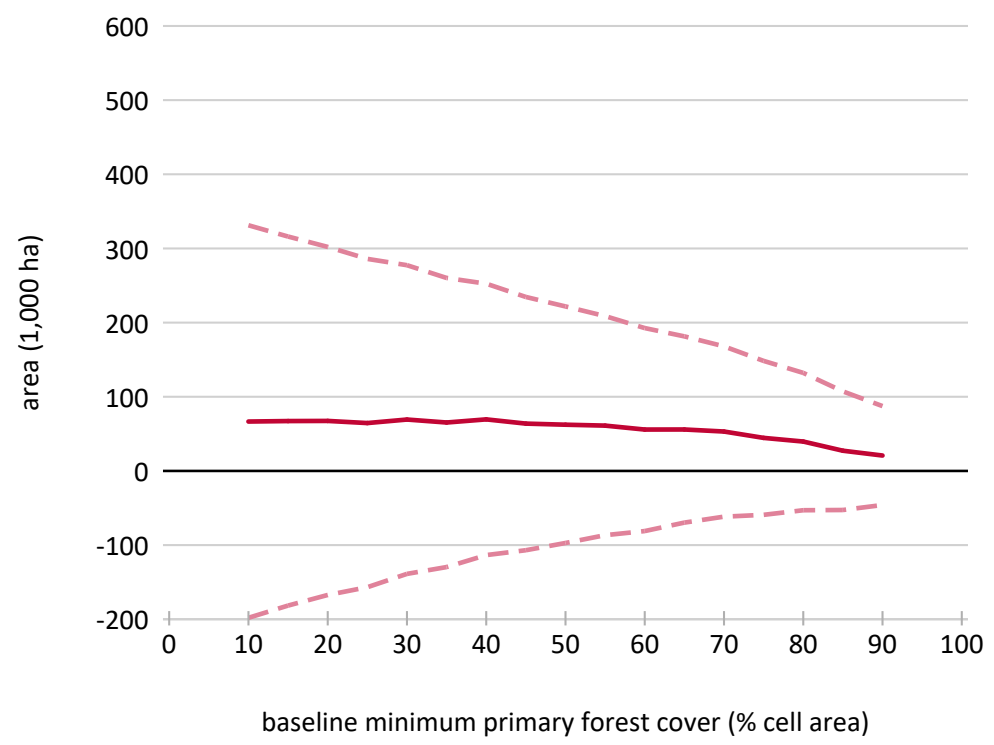

Notes: The figure illustrates the difference in total area of non-decreasing secondary vegetation in the observed and estimated counterfactual scenarios. The counterfactual is a hypothetical scenario in which there was no deforestation monitoring system (no DETER alerts). Alternative samples, plotted along the horizontal axis, are defined as Amazon biome cells that contained non-null deforestation through 2003 and met a minimum cutoff value (axis value) defined in terms of primary forest cover in 2004. Solid lines indicate counterfactual estimates, and dashed lines indicate $95 \%$ confidence intervals. Results are shown as total sample area. Counterfactual scenarios are built using results from the benchmark specification (Table 3.4, column 6) and setting the alert area equal to zero.

adopted a new monitoring system, DETER-B, which can detect areas of forest disturbance as small as 1 ha and provide more detailed information on activity within these areas (Diniz et al., 2015) - an improvement that, by far, outperforms the enhancement proposed in the counterfactual scenario. Results suggest that this new system could make significant contributions to promote Amazon regeneration.

The second, and last, counterfactual exercise proposes a diametrically opposite hypothetical scenario. In it, there is no monitoring system to issue alerts and target law enforcement, such that alert intensities in all neighborhoods are set to zero. As before, Figure 3.8 plots the difference in the total area of non-decreasing secondary vegetation, but now the counterfactual estimate is deducted from observed totals. Although point estimates are positive across all samples, suggesting that the existence of the monitoring system promoted expansion in non-decreasing secondary vegetation, they are also systematically insignificant. Little more can be said about this result without further investigation. 


\section{6}

\section{Final Remarks}

This chapter's analysis has policy implications that are both relevant and timely. From an Amazon conservation perspective, it indicates that potentially substantial policy impacts remained unaccounted for in PPCDAm effectiveness evaluations. Incorporating these impacts into policy design could significantly affect targeting and cost-benefit considerations.

Moreover, from a broader perspective, results are particularly salient in light of growing awareness regarding the need for global action to reconcile environmental and development goals. Central to this effort is the restoration of ecological integrity in degraded and deforested areas, due to its potential to mitigate climate change while improving human well-being. The emergence of international initiatives like the Bonn Challenge, which aims to restore 150 million hectares by 2020 and 350 million hectares by 2030 worldwide, attests to the mounting interest of the international community in promoting restoration at scale. Governmental commitments undertaken in the form of Nationally Determined Contributions (NDC) under the United Nations Framework Convention on Climate Change (UNFCCC) signal countries' recognition of the part they play in the pursuit of a shared interest. Brazil's NDC sets a target of reducing greenhouse gas emissions to more than $35 \%$ below its 2005 levels by 2030 , partly by restoring/reforesting 12 million hectares of forest countrywide. As an endeavor of unprecedented magnitude in the country, restoration at scale poses significant practical challenges. Knowledge regarding what contributed to the remarkable expansion of Amazon secondary vegetation, particularly in a context of heightened vulnerability for regrowth, could catalyze regeneration and thereby help Brazil achieve its environmental commitments. 


\section{Bibliography}

Abman, R. (2015). Reelection Incentives, Blacklisting and Deforestation in Brazil. San Diego State University, Department of Economics working paper.

Abman, R. (2018). Rule of Law and Avoided Deforestation from Protected Areas. Ecological Economics, 146:282-289.

Adami, M., Gomes, A. R., Beluzzo, A., Coelho, A. d. S., Valeriano, D. d. M., Ramos, F. d. S., Narvaes, I. d. S., Brown, I. F., de Oliveira, I. D., Santos, L. B., Maurano, L. E. P., Watrin, O. d. S., and Graça, P. M. L. d. A. (2017). A confiabilidade do PRODES: estimativa da acurácia do mapeamento do desmatamento no estado Mato Grosso. Anais do XVIII Simpósio Brasileiro de Sensoriamento Remoto.

Aide, T. M., Zimmerman, J. K., Pascarella, J. B., Rivera, L., and MarcanoVega, H. (2000). Forest Regeneration in a Chronosequence of Tropical Abandoned Pastures: Implications for Restoration Ecology. Restoration Ecology, 8(4):328-338.

Alix-Garcia, J. and Gibbs, H. K. (2017). Forest conservation effects of Brazil's zero deforestation cattle agreements undermined by leakage. Global Environmental Change, 47:201-217.

Alix-Garcia, J., McIntosh, C., Sims, K. R. E., and Welch, J. R. (2013). The Ecological Footprint of Poverty Alleviation: Evidence from Mexico's Oportunidades Program. The Review of Economics and Statistics, 95(2):417-435.

Alix-Garcia, J., Rausch, L. L., L'Roe, J., Gibbs, H. K., and Munger, J. (2017). Avoided Deforestation Linked to Environmental Registration of Properties in the Brazilian Amazon. Conservation Letters, pages 1-8.

Alix-Garcia, J. M., Shapiro, E. N., and Sims, K. R. E. (2012). Forest Conservation and Slippage: Evidence from Mexico's National Payments for Ecosystem Services Program. Land Economics, 88(4):613-638.

Almeida, C. A., Valeriano, D. M., Escada, M. I. S., and Rennó, C. D. (2010). Estimativa da área de vegetação secundária na Amazônia Legal Brasileira. Acta Amazonica, 40(2):289-302.

Almeida, C. A. d., Coutinho, A. C., Esquerdo, J. C. D. M., Adami, M., Venturieri, A., Diniz, C. G., Dessay, N., Durieux, L., and Gomes, A. R. (2016). High spatial resolution land use and land cover mapping of the brazilian legal amazon in 2008 using landsat-5/tm and modis data. Acta Amazonica, 46(3):291-302. 
Alston, L. J., Libecap, G. D., and Mueller, B. (2000). Land Reform Policies, the Sources of Violent Conflict, and Implications for Deforestation in the Brazilian Amazon. Journal of Environmental Economics and Management, 39:162-188.

Alves, D., Soares, J. a. V., Amaral, S., Mello, E. M. K., Almeida, S. A. S., da Silva, O. F., and Silveira, A. M. (1997). Biomass of primary and secondary vegetation in Rondônia, Western Brazilian Amazon. Global Change Biology, 3:451-461.

Andam, K. S., Ferraro, P. J., Pfaff, A., Sanchez-Azofeifa, G. A., and Robalino, J. A. (2008). Measuring the effectiveness of protected area networks in reducing deforestation. Proceedings of the National Academy of Sciences, 105(42):16089-16094.

Anderson, L. O., De Martino, S., Harding, T., Kuralbayeva, K., and Lima, A. (2016). The Effects of Land Use Regulation on Deforestation: Evidence from the Brazilian Amazon. Working paper.

Andrade, L. C. d. (2016). Spillover effects of blacklisting policy in the Brazilian Amazon. Master's thesis, Universidade de São Paulo, Faculdade De Economia, Administração e Contabilidade, Departamento de Economia.

Angelsen, A. and Kaimowitz, D. (1999). Rethinking the Causes of Deforestation: Lessons from Economic Models. World Bank Research Observer, 14(1):73-98.

Arima, E. Y., Barreto, P., Araújo, E., and Soares-Filho, B. (2014). Public policies can reduce tropical deforestation: Lessons and challenges from Brazil. Land Use Policy, 41:465-473.

Arriagada, R. A., Echeverria, C. M., and Moya, D. E. (2016). Creating Protected Areas on Public Lands: Is There Room for Additional Conservation? PLoS ONE, 11(2):e0148094.

Assunção, J., Gandour, C., Pessoa, P., and Rocha, R. (2017a). Property-level assessment of change in forest clearing patterns: The need for tailoring policy in the Amazon. Land Use Policy, 66:18-27.

Assunção, J., Gandour, C., and Roch, R. (2015). Deforestation slowdown in the Brazilian Amazon: prices or policies? Environment and Development Economics, 20(6):697-722.

Assunção, J., Gandour, C., and Rocha, R. (2017b). DETERring Deforestation in the Amazon: Environmental Monitoring and Law Enforcement. CPI \& NAPC/PUC-Rio working paper.

Assunção, J., Gandour, C., Rocha, R., and Rocha, R. (2018a). The Effect of Rural Credit on Deforestation: Evidence from the Brazilian Amazon. CPI \& NAPC/PUC-Rio working paper. 
Assunção, J., McMillan, R., Murphy, J., and Souza-Rodrigues, E. (2018b). Optimal Environmental Targeting in the Amazon Rainforest. Working paper.

Assunção, J. and Rocha, R. (2014). Getting Greener by Going Black: The Priority Municipalities in Brazil. CPI \& NAPC/PUC-Rio working paper.

Avelino, A. F. T., Baylis, K., and Honey-Rosés, J. (2016). Goldilocks and the Raster Grid: Selecting Scale when Evaluating Conservation Programs. PLoS ONE, 11(12):e0167945.

Barbier, E. B. and Burgess, J. C. (2001). The Economics of Tropical Deforestation. Journal of Economic Surveys, 15(3):413-433.

Barreto, P., Mesquita, M., Araújo, E., and Brito, B. (2009). A Impunidade de Infratores Ambientais em Áreas Protegidas da Amazônia. Technical report 13, Instituto do Homem e Meio Ambiente da Amazônia, Imazon.

Baylis, K., Honey-Rosés, J., Börner, J., Corbera, E., Ezzine-de Blas, D., Ferraro, P. J., Lapeyre, R., Persson, U. M., Pfaff, A., and Wunder, S. (2016). Mainstreaming Impact Evaluation in Nature Conservation. Conservation Letters, 9(1):58-64.

Becker, G. S. (1968). Crime and Punishment: An Economic Approach. Journal of Political Economy, 76(2):169-217.

Bertrand, M., Duflo, E., and Mullainathan, S. (2004). How Much Should We Trust Differences-in-Differences Estimates? The Quarterly Journal of Economics, 119:249-275.

Blattman, C., Green, D., Ortega, D., and Tobón, S. (2017). Pushing Crime Around the Corner? Estimating Experimental Impacts of Large-Scale Security Interventions. NBER working paper no. 23941.

Börner, J., Kis-Katos, K., Hargrave, J., and König, K. (2015). Post-Crackdown Effectiveness of Field-Based Forest Law Enforcement in the Brazilian Amazon. PLoS ONE, 10(4):e0121544.

Börner, J., Wunder, S., Wertz-Kanounnikoff, S., Hyman, G., and Nascimento, N. (2014). Forest law enforcement in the Brazilian Amazon: Costs and income effects. Global Environmental Change, 29:294-305.

Braga, A. A. and Bond, B. J. (2008). Policing Crime and Disorder Hot Spots: A Randomized Controlled Trial. Criminology, 46:577-607.

Braga, A. A., Weisburd, D. L., Waring, E. J., Mazerolle, L. G., Spelman, W., and Gajewski, F. (1999). Problem-Oriented Policing in Violent Crime Places: A Randomized Controlled Experiment. Criminology, 37:541-580.

Bragança, A. (2018). The effects of crop-to-beef relative prices on deforestation: evidence from the Tapajós Basin. Environment and Development Economics, pages $1-22$. 
Brasil (1966). Lei Agrária (Lei 4.947/1966). Brasília, DF, Brazil.

Brasil (1988). Constituição da República Federativa do Brasil. Brasília, DF, Brazil.

Brasil (1998). Lei de Crimes Ambientais (Lei 9.605/1998). Brasília, DF, Brazil.

Brasil (2007). Decreto 6.321/2007. Brasília, DF, Brazil.

Brasil (2008a). Decreto 6.514/2008. Brasília, DF, Brazil.

Brasil (2008b). Resolução 3.545 do Banco Central. Brasília, DF, Brazil.

Brasil (2012). Código Florestal (Lei 12.651/2012). Brasília, DF, Brazil.

Burgess, R., Costa, F. J. M., and Olken, B. A. (2018). Wilderness Conservation and the Reach of the State: Evidence from National Borders in the Amazon. Working paper.

Burgess, R., Hansen, M., Olken, B. A., Potapov, P., and Sieber, S. (2012). The Political Economy of Deforestation in the Tropics. The Quarterly Journal of Economics, 127:1707-1754.

Burke, M., Craxton, M., Kolstad, C. D., Onda, C., Allcott, H., Baker, E., Barrage, L., Carson, R., Gillingham, K., Graff-Zivin, J., Greenstone, M., Heal, G., Hsiang, S., Jones, B., Kelly, D. L., Kopp, K., Kotchen, M., Mendelsohn, R., Meng, K., Metcalf, G., Moreno-Cruz, J., Pindyck, R., Rose, S., Rudik, I., Stock, J., and Tol, R. S. J. (2016). Opportunities for advances in climate change economics. Science, 352:292-293.

Busch, J. and Ferretti-Gallon, K. (2017). What Drives Deforestation and What Stops It? A Meta-Analysis. Review of Environmental Economics and Policy, $11: 3-23$.

Casa Civil (2004). Plano de Ação para a Prevenção e Controle do Desmatamento na Amazônia Legal. Operational plan, Grupo Permanente de Trabalho Interministerial para a Redução dos Índices de Desmatamento da Amazônia Legal, Casa Civil, Presidência da República, Brasília, DF, Brazil.

Caviglia-Harris, J. L., Toomey, M., Harris, D. W., Mullan, K., Bell, A. R., Sills, E. O., and Roberts, D. A. (2015). Detecting and interpreting secondary forest on an old Amazonian frontier. Journal of Land Use Science, 10:442465.

Chazdon, R. L. (2008). Beyond Deforestation: Restoring Forests and Ecosystem Services on Degraded Lands2008. Science, 320:1458.

Chiavari, J. and Lopes, C. L. (2015). Brazil's New Forest Code: Part I - How to Navigate the Complexity. Technical report, Climate Policy Initiative / INPUT.

Chiavari, J., Lopes, C. L., Marques, D., Antonaccio, L., and Braga, N. (2016). Panorama dos direitos de propriedade no brasil rural: Legislação, gestão fundiária e código florestal. Technical report, Climate Policy Initiative. 
Chimelli, A. B. and Soares, R. R. (2017). The Use of Violence in Illegal Markets: Evidence from Mahogany Trade in the Brazilian Amazon. American Economic Journal: Applied Economics, 9(4):30-57.

Chomitz, K. M. and Gray, D. A. (1996). Roads, Land Use, and Deforestation: A Spatial Model Applied to Belize. The World Bank Economic Review, 10(3):487-512.

Chomitz, K. M. and Thomas, T. S. (2003). Determinants of Land Use in Amazônia: A Fine-Scale Spatial Analysis. American Journal of Agricultural Economics, 85(4):1016-1028.

Cisneros, E. (2017). The Impact of Public Policies on Deforestation in the Brazilian Amazon. PhD thesis, Universität Bonn.

Cisneros, E., Hargrave, J., and Kis-Katos, K. (2013). Unintended consequences of anti-corruption strategies: Public fiscal audits and deforestation in the Brazilian Amazon. Working paper.

Cisneros, E., Zhou, S. L., and Börner, J. (2015). Naming and Shaming for Conservation: Evidence from the Brazilian Amazon. PLoS ONE, 10(9):e0136402.

Cropper, M. and Griffiths, C. (1994). The Interaction of Population Growth and Environmental Quality. The American Economic Review: Papers and Proceedings, 84(2):250-254. Papers and Proceedings of the Hundred and Sixth Annual Meeting of the American Economic Association.

Crouzeilles, R., Curran, M., Ferreira, M. S., Lindenmayer, D. B., Grelle, C. E. V., and Benayas, J. M. R. (2016). A global meta-analysis on the ecological drivers of forest restoration success. Nature Communications, 7:11666.

Crouzeilles, R., Ferreira, M. S., Chazdon, R. L., Lindenmayer, D. B., Sansevero, J. B. B., Monteiro, L., Iribarrem, A., Latawiec, A. E., and Strassburg, B. B. N. (2017). Ecological restoration success is higher for natural regeneration than for active restoration in tropical forests. Science Advances, 3:e1701345.

DeFries, R., Hansen, A., Newton, A. C., and Hansen, M. C. (2005). Increasing Isolation of Protected Areas in Tropical Forests Over the Past Twenty Years. Ecological Applications, 15(1):19-26.

Dell, M., Jones, B. F., and Olken, B. A. (2014). What Do We Learn from the Weather? The New Climate-Economy Literature. Journal of Economic Literature, 52(3):740-798.

Diniz, C. G., de Almeida Souza, A. A., Santos, D. C., Dias, M. C., da Luz, N. C., de Moraes, D. R. V., Maia, J. S., Gomes, A. R., da Silva Narvaes, I., Valeriano, D. M., Maurano, L. E. P., and Adami, M. (2015). DETERB: The New Amazon Near Real-Time Deforestation Detection System. IEEE Journal of Selected Topics in Applied Earth Observations and Remote Sensing, 8(7):3619-3628. 
Donaldson, D. and Storeygard, A. (2016). The View from Above: Applications of Satellite Data in Economics. Journal of Economic Perspectives, 30(4):171198.

Fetzer, T. and Marden, S. (2017). Take What You Can: Property Rights, Contestability and Conflict. Economic Journal, 127:757-783.

Foster, A. D. and Rosenzweig, M. R. (2003). Economic Growth and the Rise of Forests. The Quarterly Journal of Economics, 118(2):601-637.

Gaveau, D. L. A., Curran, L. M., Paoli, G. D., Carlson, K. M., Wells, P., Besse-Rimba, A., Ratnasari, D., and Leader-Williams, N. (2012). Examining protected area effectiveness in Sumatra: importance of regulations governing unprotected lands. Conservation Letters, 5:142-148.

Gibbs, H. K., Rausch, L., Munger, J., Schelly, I., Morton, D. C., Noojipady, P., Soares-Filho, B., Barreto, P., Micol, L., and Walker, N. F. (2015). Brazil's Soy Moratorium. Science, 347:377-378.

Godar, J., Gardner, T. A., Tizado, E. J., and Pacheco, P. (2014). Actor-specific contributions to the deforestation slowdown in the Brazilian Amazon. Proceedings of the National Academy of Sciences, 111(43):15591-15596.

Godar, J., Tizado, E. J., and Pokorny, B. (2012). Who is responsible for deforestation in the Amazon? A spatially explicit analysis along the Transamazon Highway in Brazil. Forest Ecology and Management, 267:58 73.

Gollnow, F., Hissa, L. d. B. V., Rufin, P., and Lakes, T. (2018). Propertylevel direct and indirect deforestation for soybean production in the Amazon region of Mato Grosso, Brazil. Land Use Policy, 78:377-385.

Greenstone, M. and Hanna, R. (2014). Environmental Regulations, Air and Water Pollution, and Infant Mortality in India. The American Economic Review, 104(10):3038-3072.

Greenstone, M. and Jack, B. K. (2015). Envirodevonomics: A Research Agenda for an Emerging Field. Journal of Economic Literature, 53(1):5-42.

Guariguata, M. R. and Ostertag, R. (2001). Neotropical secondary forest succession: changes in structural and functional characteristics. Forest Ecology and Management, 148:185-206.

Hansen, M. C. and DeFries, R. S. (2004). Detecting Long-term Global Forest Change Using Continuous Fields of Tree-Cover Maps from 8-km Advanced Very High Resolution Radiometer (AVHRR) Data for the Years 1982-99. Ecosystems, 7:695-716.

Hansen, M. C., Stehman, S. V., Potapov, P. V., Loveland, T. R., Townshend, J. R. G., DeFries, R. S., Pittman, K. W., Arunarwati, B., Stolle, F., Steininger, M. K., Carroll, M., and Dimiceli, C. (2008). Humid tropical forest clearing from 2000 to 2005 quantified by using multitemporal and multiresolution 
remotely sensed data. Proceedings of the National Academy of Sciences, 105(27):9439-9444.

Hargrave, J. and Kis-Katos, K. (2013). Economic Causes of Deforestation in the Brazilian Amazon: A Panel Data Analysis for the 2000s. Environmental and Resource Economics, 54:471-494.

Herrera, L. D. (2015). Protected Areas' Deforestation Spillovers and Two Critical Underlying Mechanisms: An Empirical Exploration for the Brazilian Amazon. PhD thesis, University Program in Environmental Policy, Duke University.

Honey-Rosés, J., Baylis, K., and Ramírez, M. I. (2011). A Spatially Explicit Estimate of Avoided Forest Loss. Conservation Biology, 25(5):1032-1043.

Inpe (2013). Metodologia para o Cálculo da Taxa Anual de Desmatamento na Amazônia Legal. Technical report, Instituto Nacional de Pesquisas Espaciais (Inpe), Ministério da Ciência, Tecnologia e Inovação (MCTI). Original text by Gilberto Câmara, Dalton de Morisson Valeriano, and João Vianei Soares (Sep/2006). Revised by Marisa da Mota (Apr/2010) and Luis Maurano (Oct/2013).

Inpe (2017). Projeto PRODES - Monitoramento da Floresta Amazônica Brasileira por Satélite. Database, Instituto Nacional de Pesquisas Espaciais (Inpe), Ministério da Ciência, Tecnologia e Inovação (MCTI). Accessed in November 2017.

Inpe and Embrapa (2016a). TerraClass Amazônia. Database, Instituto Nacional de Pesquisas Espaciais (Inpe), Ministério da Ciência, Tecnologia e Inovação (MCTI) and Empresa Brasileira de Pesquisa Agropecuária (Embrapa), Ministério da Agricultura, Pecuária e Abastecimento (MAPA). Accessed in August 2016.

Inpe and Embrapa (2016b). TerraClass Amazônia, Sumário Executivo 2004-2014. Technical report, Instituto Nacional de Pesquisas Espaciais (Inpe), Ministério da Ciência, Tecnologia e Inovação (MCTI) and Empresa Brasileira de Pesquisa Agropecuária (Embrapa), Ministério da Agricultura, Pecuária e Abastecimento (MAPA).

IPCC (2007). Climate Change 2007. Synthesis report, Intergovernmental Panel on Climate Change.

Jayachandran, S., de Laat, J., Lambin, E. F., Stanton, C. Y., Audy, R., and Thomas, N. E. (2017). Cash for Carbon: A randomized controlled trial of payments for ecosystem services to reduce deforestation. Science, 357:267273.

Joppa, L. N., Loarie, S. R., and Pimm, S. L. (2008). On the protection of "protected areas". Proceedings of the National Academy of Sciences, 105(18):6673-6678.

Joppa, L. N. and Pfaff, A. (2011). Global protected area impacts. Proceedings of the Royal Society B: Biological Sciences, 278(1712):1633-1638. 
Koch, N., zu Ermgassen, E. K. H. J., Johanna, W., Oliveira, F., and Schwerhoff, G. (2018). Agricultural Productivity and Forest Conservation: Evidence from the Brazilian Amazon. Working paper.

Lambin, E. F., Gibbs, H. K., Heilmayr, R., Carlson, K. M., Fleck, L. C., Garrett, R. D., de Waroux, Y. l. P., McDermott, C. L., McLaughlin, D., Newton, P., Nolte, C., Pacheco, P., Rausch, L. L., Streck, C., Thorlakson, T., and Walker, N. F. (2018). The role of supply-chain initiatives in reducing deforestation. Nature Climate Change, 8:109-116.

Latawiec, A. E., Crouzeilles, R., Brancalion, P. H. S., Rodrigues, R. R., Sansevero, J. B., Santos, J. S. d., Mills, M., Nave, A. G., and Strassburg, B. B. (2016). Natural regeneration and biodiversity: a global meta-analysis and implications for spatial planning. Biotropica, 48(6):844-855.

L'Roe, J., Rausch, L., Munger, J., and Gibbs, H. K. (2016). Mapping properties to monitor forests: Landholder response to a large environmental registration program in the Brazilian Amazon. Land Use Policy, 57:193-203.

Macedo, M. N., DeFries, R. S., Morton, D. C., Stickler, C. M., Galford, G. L., and Shimabukuro, Y. E. (2012). Decoupling of deforestation and soy production in the southern Amazon during the late 2000s. Proceedings of the National Academy of Sciences, 109(4):1341-1346.

Maia, H., Hargrave, J., Gómez, J. J., and Röper, M. (2011). Avaliação do Plano de Ação para Prevenção e Controle do Desmatamento na Amazônia Legal. Technical report, Deutsche Gesellschaft für Internationale Zusammenarbeit (GIZ), Instituto de Pesquisa Econômica Aplica (Ipea), and Comissão Econômica para a América Latina e o Caribe (Cepal), Brasília, Distrito Federal, Brazil.

Manski, C. F. (1993). Identification of Endogenous Social Effects: The Reflection Problem. The Review of Economic Studies, 60(3):531-542.

Matsuura, K. and Willmott, C. J. (2015). Terrestrial Precipitation and Air Temperature: 1900-2014 Gridded Monthly Time Series (V4.01). Database, University of Delaware. Accessed in November 2016.

MCTI (2013). Estimativas anuais de emissões de gases de efeito estufa no Brasil. Technical report, Coordenação Geral de Mudanças Globais de Clima (CGMC), Secretaria de Políticas e Programas de Pesquisa e Desenvolvimento (SEPED), Ministério da Ciência, Tecnologia e Inovação (MCTI), Brasília, DF, Brazil.

Michalski, F., Metzger, J. P., and Peres, C. A. (2010). Rural property size drives patterns of upland and riparian forest retention in a tropical deforestation frontier. Global Environmental Change, 20:705-712.

Miranda, J. J., Corral, L., Blackman, A., Asner, G., and Lima, E. (2016). Effects of Protected Areas on Forest Cover Change and Local Communities: Evidence from the Peruvian Amazon. World Development, 78:288-307. 
MMA (2016). Plano de Ação para Prevenção e Controle do Desmatamento na Amazônia Legal: Plano Operativo 2016-2020. Operational plan, Ministério do Meio Ambiente (MMA), Brasília, DF, Brazil.

Mueller, B., Alston, L., Libecap, G. D., and Schneider, R. (1994). Land, Property Rights and Privatization in Brazil. The Quarterly Review of Economics and Finance, 34(Special Issue):261-280.

Nelson, A. and Chomitz, K. M. (2011). Effectiveness of Strict vs. Multiple Use Protected Areas in Reducing Tropical Forest Fires: A Global Analysis Using Matching Methods. PLoS ONE, 6:e22722.

Nepstad, D., Schwartzman, S., Bamberger, B., Santilli, M., Ray, D., Schlesinger, P., Lefebvre, P., Alencar, A., Prinz, E., Fiske, G., and Rolla, A. (2006). Inhibition of Amazon Deforestation and Fire by Parks and Indigenous Lands. Conservation Biology, 20(1):65-73.

Nolte, C., Agrawal, A., Silvius, K. M., and Soares-Filho, B. S. (2013). Governance regime and location influence avoided deforestation success of protected areas in the Brazilian Amazon. Proceedings of the National Academy of Sciences, 110(13):4956-4961.

Pacheco, P. (2009). Agrarian Reform in the Brazilian Amazon: Its Implications for Land Distribution and Deforestation. World Development, 37(8):13371347.

Pailler, S. (2018). Re-election incentives and deforestation cycles in the Brazilian Amazon. Journal of Environmental Economics and Management, 88:345-365.

Pellegrina, H. S. (2015). Agricultural Trade and the Spatial Allocation of Farmers: Implications for Deforestation in Brazil. Working paper.

Perz, S. G. and Walker, R. T. (2002). Household Life Cycles and Secondary Forest Cover Among Small Farm Colonists in the Amazon. World Development, 30(6):1009-1027.

Pfaff, A. and Robalino, J. (2017). Spillovers from Conservation Programs. Annual Review of Resource Economics, 9:299-315.

Pfaff, A., Robalino, J., Herrera, D., and Sandoval, C. (2015a). Protected Areas' Impacts on Brazilian Amazon Deforestation: Examining Conservation - Development Interactions to Inform Planning. PLoS ONE, 10(7):e0129460.

Pfaff, A., Robalino, J., Lima, E., Sandoval, C., and Herrera, L. D. (2014). Governance, Location and Avoided Deforestation from Protected Areas: Greater Restrictions Can Have Lower Impact, Due to Differences in Location. World Development, 55:7-20.

Pfaff, A., Robalino, J., Sanchez-Azofeifa, G. A., Andam, K. S., and Ferraro, P. J. (2009). Park Location Affects Forest Protection: Land Characteristics Cause Differences in Park Impacts across Costa Rica. The B.E. Journal of Economic Analysis \& Policy, 9. 
Pfaff, A., Robalino, J., Sandoval, C., and Herrera, D. (2015b). Protected area types, strategies and impacts in Brazil's Amazon: public protected area strategies do not yield a consistent ranking of protected area types by impact. Philosophical Transactions of the Royal Society B, 370:20140273.

Pfaff, A., Robalino, J., Walker, R., Aldrich, S., Caldas, M., Reis, E., Perz, S., Bohrer, C., Arima, E., Laurance, W., and Kirby, K. (2007). Road Investments, Spatial Spillovers, and Deforestation in the Brazilian Amazon. Journal of Regional Science, 47(1):109-123.

Pfaff, A. S. P. (1999). What Drives Deforestation in the Brazilian Amazon? Evidence from Satellite and Socioeconomic Data. Journal of Environmental Economics and Management, 37:26-43.

Rappaport, D. I., Morton, D. C., Longo, M., Keller, M., Dubayah, R., and dos Santos, M. N. (2018). Quantifying long-term changes in carbon stocks and forest structure from Amazon forest degradation. Environmental Research Letters, 13:065013.

Richards, P. D. and VanWey, L. (2016). Farm-scale distribution of deforestation and remaining forest cover in Mato Grosso. Nature Climate Change, 6:418 425 .

Robalino, J., Pfaff, A., and Villalobos, L. (2017). Heterogeneous Local Spillovers from Protected Areas in Costa Rica. Journal of the Association of Environmental and Resource Economists, 4(3):795-820.

Robalino, J., Sandoval, C., Barton, D. N., Chacon, A., and Pfaff, A. (2015). Evaluating Interactions of Forest Conservation Policies on Avoided Deforestation. PLoS ONE, 10(4):e0124910.

Robalino, J. A. and Pfaff, A. (2012). Contagious development: Neighbor interactions in deforestation. Journal of Development Economics, 97(2):427436.

Rosa, I. M. D., Souza, C., and Ewers, R. M. (2012). Changes in Size of Deforested Patches in the Brazilian Amazon. Conservation Biology, 26(5):932-937.

Rudorff, B. F. T., Adami, M., Aguiar, D. A., Moreira, M. A., Mello, M. P., Fabiani, L., Amaral, D. F., and Pires, B. M. (2011). The Soy Moratorium in the Amazon Biome Monitored by Remote Sensing Images. Remote Sensing, 3:185-202.

Salum, M. R. B., Gomes, A. R., and Diniz, C. G. (2011). Validação do mapeamento de vegetação secundária do projeto TerraClass para município de Bragança, Estado do Pará. Anais do XV Simpósio Brasileiro de Sensoriamento Remoto.

Schmitt, J. (2015). Crime sem castigo: a efetividade da fiscalização ambiental para o controle do desmatamento ilegal na Amazônia. PhD thesis, Centro de Desenvolvimento Sustentável, Universidade de Brasília, Brasília, DF. 
SFB (2017). Cadastro Ambiental Rural. Database, Serviço Florestal Brasileiro (SFB), Ministério do Meio Ambiente (MMA). Accessed on November, 07, 2017.

Shah, P. and Baylis, K. (2015). Evaluating Heterogeneous Conservation Effects of Forest Protection in Indonesia. PLoS ONE, 10(6):e0124872.

Sills, E. O., Herrera, D., Kirkpatrick, A. J., Brandão Jr, A., Dickson, R., Hall, S., Pattanayak, S., Shoch, D., Vedoveto, M., Young, L., and Pfaff, A. (2015). Estimating the Impacts of Local Policy Innovation: The Synthetic Control Method Applied to Tropical Deforestation. PLoS ONE, 10(7):e0132590.

Sims, K. R. E. (2010). Conservation and development: Evidence from Thai protected areas. Journal of Environmental Economics and Management, 60:94-114.

Sims, K. R. E. (2014). Do Protected Areas Reduce Forest Fragmentation? A Microlandscapes Approach. Environmental and Resource Economics, 58:303-333.

Sims, K. R. E. and Alix-Garcia, J. M. (2017). Parks versus PES: Evaluating direct and incentive-based land conservation in Mexico. Journal of Environmental Economics and Management, 86:8-28.

Soares-Filho, B., Moutinho, P., Nepstad, D., Anderson, A., Rodrigues, H., Garcia, R., Dietzsch, L., Merry, F., Bowman, M., Hissa, L., Silvestrini, R., and Maretti, C. (2010). Role of Brazilian Amazon protected areas in climate change mitigation. Proceedings of the National Academy of Sciences, 107(24):10821-10826.

Souza Jr., C. M., Siqueira, J. V., Sales, M. H., Fonseca, A. V., Ribeiro, J. G., Numata, I., Cochrane, M. A., Barber, C. P., Roberts, D. A., and Barlow, J. (2013). Ten-Year Landsat Classification of Deforestation and Forest Degradation in the Brazilian Amazon. Remote Sensing, 5:5493-5513.

Souza-Rodrigues, E. (2018). Deforestation in the Amazon: A Unified Framework for Estimation and Policy Analysis. Working paper.

Stern, N. (2008). The Economics of Climate Change. The American Economic Review: Papers and Proceedings, 98(2):1-37. Papers and Proceedings of the One Hundred Twentieth Annual Meeting of the American Economic Association.

Taylor, B., Koper, C. S., and Woods, D. J. (2011). A randomized controlled trial of different policing strategies at hot spots of violent crime. Journal of Experimental Criminology, 7:149-181.

Turubanova, S., Potapov, P. V., Tyukavina, A., and Hansen, M. (2018). Ongoing primary forest loss in Brazil, Democratic Republic of the Congo, and Indonesia. Environmental Research Letters, 13:074028. 
Tyukavina, A., Hansen, M. C., Potapov, P. V., Stehman, S. V., SmithRodriguez, K., Okpa, C., and Aguilar, R. (2017). Types and rates of forest disturbance in Brazilian Legal Amazon, 2000-2013. Science Advances, 3:e1601047.

Uriarte, M. and Chazdon, R. L. (2016). Incorporating natural regeneration in forest landscape restoration in tropical regions: Synthesis and key research gaps. Biotropica, 48(6):915-924.

Vieira, I. C. G. (2013). Dinâmica de uso da terra e regeneração de florestas em uma paisagem antrópica do leste do Pará. In C. Peres, J. Barlow, T. Gardner, I. C. G. Vieira (Eds.), Conservação da Biodiversidade em Paisagens Antropizadas do Brasil (pp. 83-93). Curitiba, Paraná: Editora Universidade Federal do Paraná, UFPR.

Vieira, I. C. G., Almeida, A. S. d., Davidson, E. A., Stone, T. A., Carvalho, C. J. R. d., and Guerrero, J. B. (2003). Classifying successional forests using Landsat spectral properties and ecological characteristics in eastern Amazônia. Remote Sensing of Environment, 87:470-481.

Weinhold, D. and Reis, E. (2008). Transportation costs and the spatial distribution of land use in the Brazilian Amazon. Global Environmental Change, 18:54-68. 


\section{Appendix A \\ Spatial Setup}

\section{A.1 \\ Georeferenced Raster Structure}

A raster is a matrix data structure that represents a regular grid of cells. For a given variable of interest taking on a range of possible values, each raster cell can hold one, and only one, value. Georeferenced rasters contain spatial information that associate it with a well defined region of the world's surface: (i) the coordinate reference system, which determines the origin and set of spatial axes to be used with geographical coordinates; (ii) the spatial extent, which defines the minimum and maximum limits of the area covered by the raster; and (iii) the spatial resolution, which sets raster cell size and thereby, given (i) and (ii), determines the number of rows/columns in a raster. In georeferenced rasters, each cell holds a specific position in space, as marked by the coordinates of that cell's centroid. This enables the recovery of spatial relationships, such as the distance between two cells. Moreover, it allows for the tracking of the same cell across different rasters, as long as all share the same coordinate reference system, extent, and spatial resolution.

The coordinate reference system used for dataset construction is the unprojected 1969 South American Datum (SAD69). All mentions of metric distances are metric equivalences of measures actually in degrees. The spatial resolution is set at $900 \mathrm{~m}$, such that the raster unit is a square raster cell with an area of 81ha. Construction of variables stated as shares of cell area are based on georeferenced rasters with the higher $30 \mathrm{~m}$ resolution. Typically, each of the $900 \mathrm{~m}$ cells contains 900 of the $30 \mathrm{~m}$ minicells, though the existence of spatial boundaries may result in lower minicell count in frontier cells. Shares are always calculated in terms of total cell-specific minicell count. Each minicell is associated with its respective parent cell using an indexation algorithm. Figure A.1 depicts cells, minicells, and the relationship between them.

Cell neighborhoods refer to the areas covered by concentric rings of increasing diameter around the cell. Larger neighborhoods do not contain smaller ones, and the cell itself is excluded from the smallest neighborhood. Figure A.2 illustrates raster cell neighborhoods. All cells within a given 
Figure A.1: Raster Grid, Cell, and Minicell

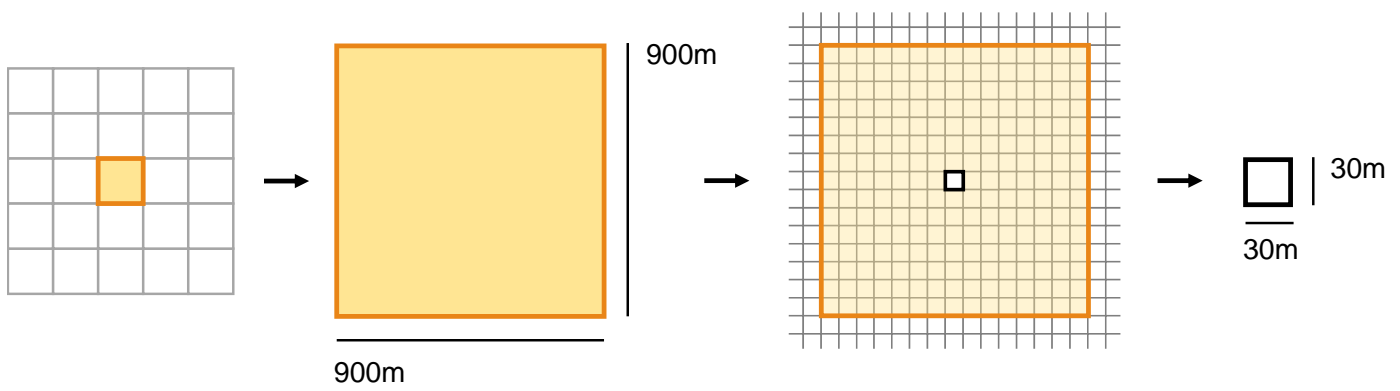

Notes: The figure illustrates the basic structure of the raster data used in the empirical analyses. The grid is composed of $900 \mathrm{~m}$ by $900 \mathrm{~m}$ square cells, which, in turn, subdivides into $30 \mathrm{~m}$ by $30 \mathrm{~m}$ square minicells. The cells and minicells in the figure are not drawn to scale.

Figure A.2: Raster Cell Neighborhoods
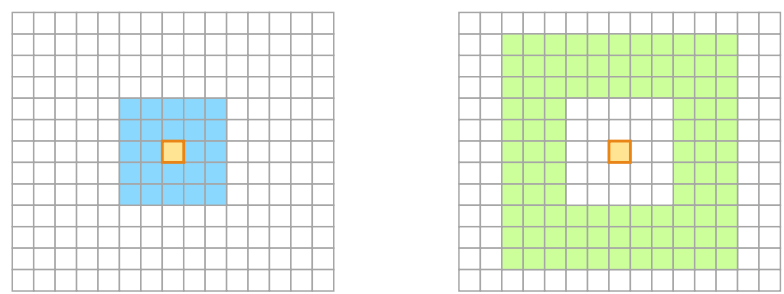

Notes: The figure illustrates raster cell neighborhoods, as determined by concentric rings of increasing diameter around the cell. Larger neighborhoods do not contain smaller ones, and the cell itself is excluded from the smallest neighborhood.

neighborhood are weighed equally, despite variation in distance to and direction from the central cell.

\section{A.2}

\section{Geographical Regions}

The Brazilian Legal Amazon is a geopolitical administrative subdivision that encompasses Acre, Amapá, Amazonas, Mato Grosso, Pará, Rondônia, Roraima, and Tocantins states, as well as the western part of Maranhão state. The Amazon biome is entirely contained within the Legal Amazon, but is defined based on biophysical and ecological criteria. Figure 2.4 maps the Brazilian Legal Amazon and Amazon biome. IBGE provides vector data indicating spatial boundaries for both. When rasterized at the $900 \mathrm{~m}$ resolution, the Brazilian Legal Amazon and Amazon biome territories contain about 6.3 and 5.2 million cells, respectively. 


\section{Appendix B \\ Data Sources and Descriptions}

\section{B.1}

\section{Land Cover and Land Use}

Brazil's systems for detecting tropical forest loss are widely recognized as being at the forefront of national efforts to combat deforestation (Tyukavina et al., 2017). The country has used satellite imagery to map and quantify Amazon deforested area since the late 1980s. Today, it operates three different remote sensing-based programs for the Amazon. The programs interact, but each serves a specific goal: (i) measure annual tropical deforestation; (ii) monitor tropical forest disturbance; and (iii) classify land use in deforested areas.

\section{B.1.1 \\ Measuring Deforestation}

The Project for Monitoring Deforestation in the Legal Amazon (PRODES), established by Inpe in 1988, provides georeferenced data on annual tropical deforested area. The system detects forest clearings by comparing, for any given area, satellite imagery from years $t-1$ and $t$ to detect changes in land cover. When an area is identified as deforested in satellite imagery, it is classified as part of that year's deforestation increment; as of the following year, it is taken as accumulated deforestation and is not revisited. Accumulated deforestation is known as the "PRODES mask". The top panel in Figure B.1 presents a conceptual illustration of how PRODES works: in year 1 , the system maps and records deforested area; in year 2, the system no longer looks for clearings inside this area, but maps and records new patches of cleared forest outside it; in year 3 and beyond, this process repeats itself, with total deforested area through the previous year being incorporated into the PRODES mask and the system looking for new deforestation outside this mask. This setup has two important consequences. First, PRODES only detects the clearing of primary vegetation (forest that has never been cut down). Second, and relatedly, it is an incremental system, such that, for each year of data, it provides information on newly deforested 
Figure B.1: Satellite Systems for Detecting Forest Disturbances

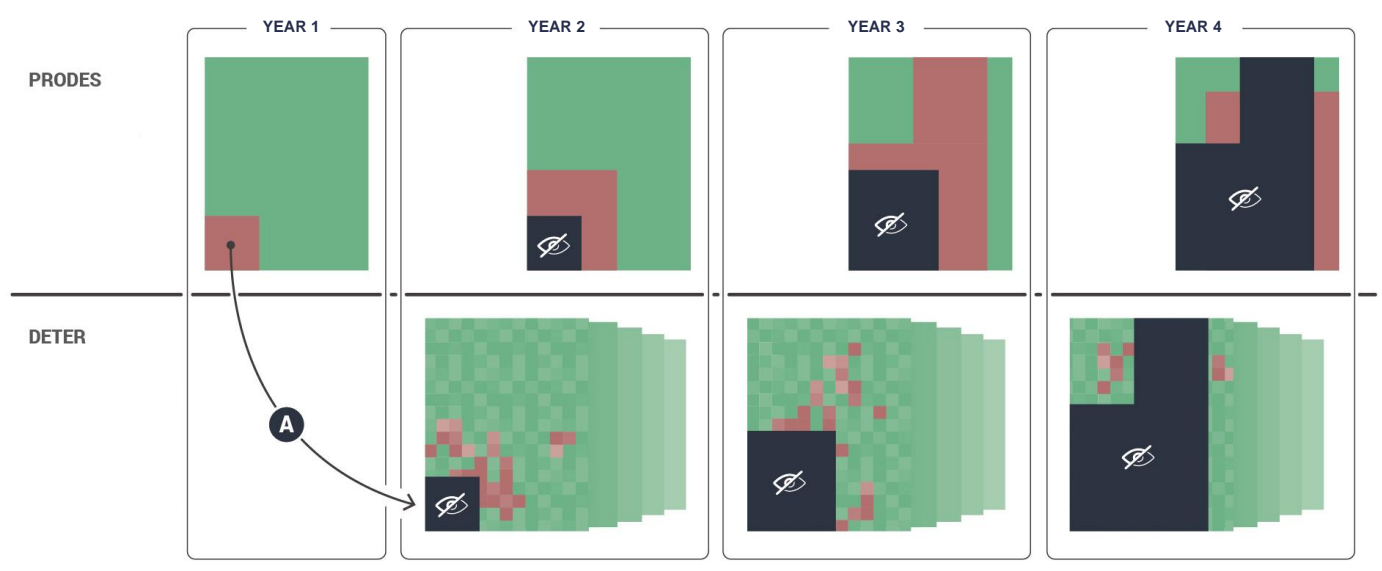

Notes: The figure presents a conceptual illustration of how satellite-based PRODES and DETER systems operate at an annual basis. The top panel refers to PRODES: in year 1, the system maps and records deforested area; in year 2, the system no longer looks for clearings inside this area, but maps and records new patches of cleared forest outside it; as of year 3, the process repeats itself. PRODES data is annual. The bottom panel refers to DETER: in year 1, the system takes input from PRODES (region A); in year 2, the system looks for signs of disturbance in forest areas outside the PRODES mask and issues deforestation hot spot alerts accordingly; at the end of year 2, PRODES will either confirm or reject deforested status for these areas, and only those that are confirmed are incorporated into the PRODES mask; in year 3 and beyond, the process repeats itself, with DETER always looking for signs of forest disturbance in forest areas outside the mask. DETER alerts are forwarded to law enforcement daily, but data is made publicly available in monthly aggregates. Both PRODES and DETER are built to only capture loss of primary tropical vegetation.

areas, but never reclassifies previously cleared areas. This implies that the PRODES mask is, by construction, non-decreasing in area.

The system classifies land cover throughout the full extent of the Brazilian Legal Amazon into five categories of mutually-exclusive classes: forest (standing primary vegetation), deforestation, bodies of water, non-forest (areas that have never been covered by tropical vegetation), and residue (a minor residual category). Only tropical forest areas can ever be deforested, as PRODES is not technically fit to compute the clearing of other types of vegetation. Although the Brazilian Legal Amazon is mostly covered by tropical forest, some areas, particularly those outside the Amazon biome, are naturally covered by savanna-like cerrado vegetation - these areas are classified as non-forest in PRODES and are not accounted for in official Amazon deforestation statistics. Because clouds, shadows cast by clouds, and smoke from fires obstruct visibility in satellite imagery, some areas might be classified into a sixth category: non-observable areas. Actual land cover in these areas is only classified once the visual obstruction clears.

PRODES was created, and is still used, to calculate the Amazon-wide deforestation rate. While the deforestation increment measures total visible deforested area, the deforestation rate accounts for an estimate of cleared forest areas that were partially or entirely blocked from view during remote sensing. 
The rate thereby attempts to more closely capture the speed at which the Amazon was cleared, while the increment reflects when the cleared area became known to authorities. ${ }^{1}$ Only the deforestation increment is made available as spatial data.

PRODES uses imagery from Landsat class satellites with a spatial resolution of 20 to $30 \mathrm{~m}$. When the system was implemented, technical limitations restricted detection to deforestation patches larger than 6.25ha. Today, although smaller patches are detected, processed, and forwarded to environmental authorities, public data are restricted to patches larger than 6.25ha to preserve comparability across the time series. In addition, the system only detects areas that have been clear-cut, so selective logging and forest degradation are not included. Deforested area measured by PRODES has been validated both internally, via Inpe-led field-based accuracy evaluations (Adami et al., 2017), and externally, via third-party independent interpretation of satellite imagery (Souza Jr. et al., 2013; Turubanova et al., 2018). Cross-validations only refer to clear-cut deforestation, as PRODES does not detect tropical degradation. As expected, analyses that account for degradation estimate larger areas of affected forest (Souza Jr. et al., 2013; Tyukavina et al., 2017).

Inpe annually releases updates to the PRODES series in vector format, such that year $t$ data contain a spatial history of all areas deforested through that year and their associated year of deforestation. However, deforestation years do not refer to calendar years. To minimize cloud cover and thereby maximize visibility of the Earth's surface, satellite images from the Amazon dry season are typically used. Hence, for a given year $t$, PRODES measures deforestation that happened from August of the previous year $(t-1)$ through July of that year $(t)$. The datasets in this dissertation are built to fit this August-through-July window. For simplicity, I refer to this time frame simply as "year" throughout the analyses.

Figure B.2a plots total deforested area for the 2006 through 2014 sample period. PRODES vector data are currently available through 2016, but the historical spatial series is only comparable through 2014. This is because, in 2015, Inpe implemented a mask shift - a non-linear spatial displacement to adjust for inaccuracies that accumulated over time. Unfortunately, during this procedure, the full history of clearings prior to 2013 was collapsed and all areas cleared until then became aggregated under the 2012 year reference. As restricting the sample to the post-2012 period would result in the loss of seven

\footnotetext{
${ }^{1}$ See Inpe (2013) for a detailed account of PRODES methodology and deforestation rate estimation details.
} 
Figure B.2: Detected Forest Disturbances

(a) measuring deforestation: deforested area, 2006-2014

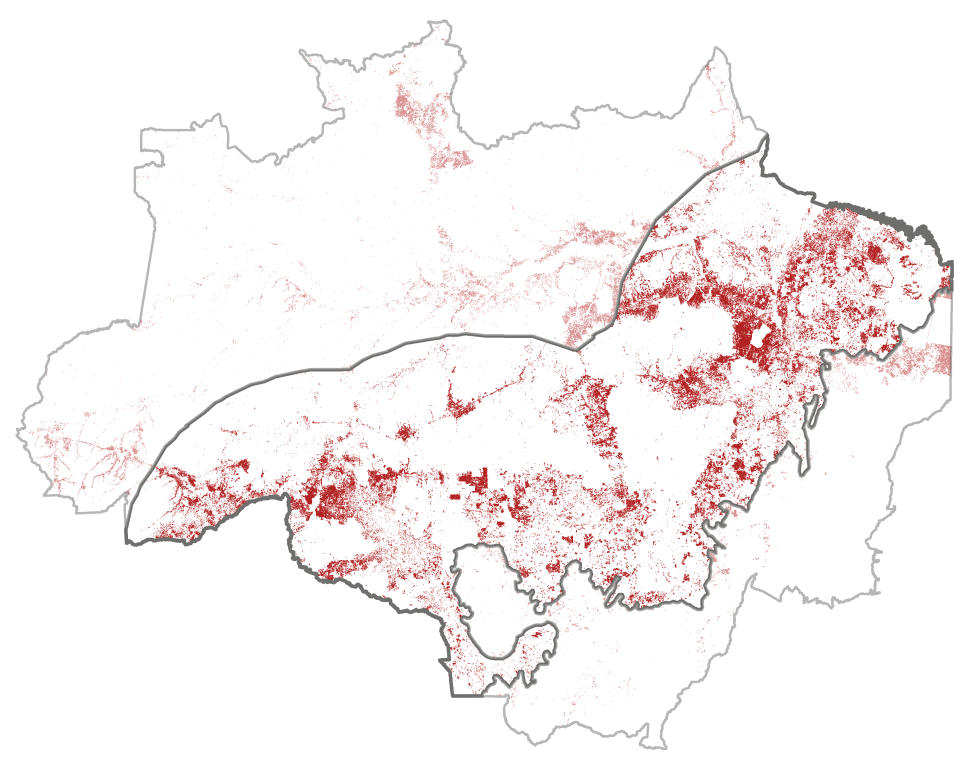

(b) monitoring deforestation: alert area, 2006-2014

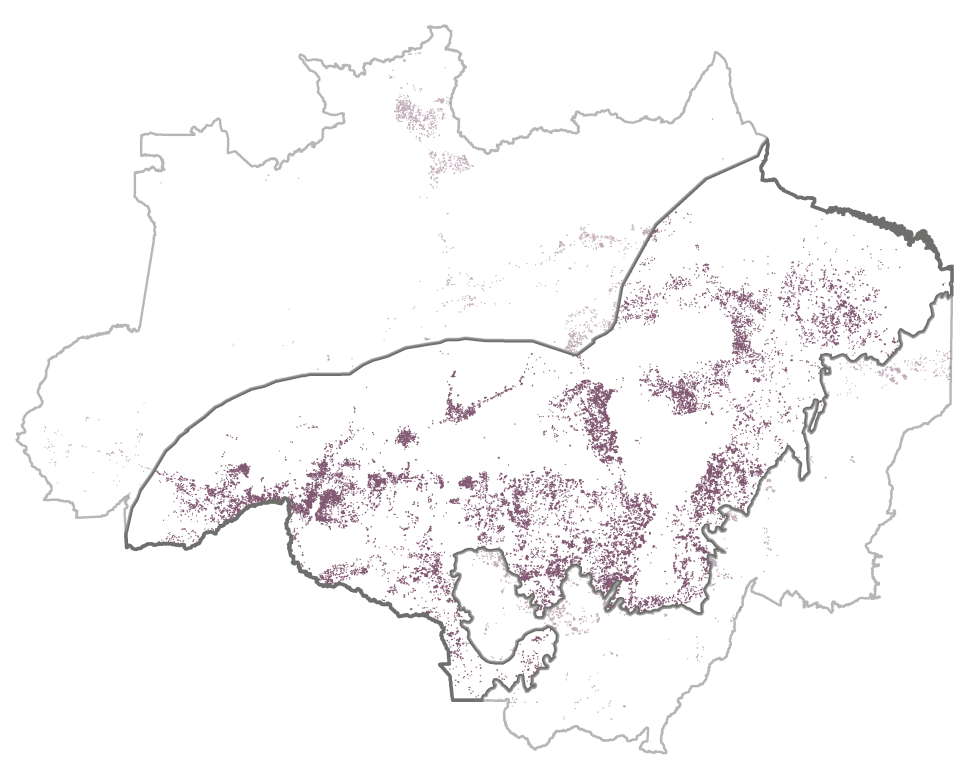

deforested area

deforestation alerts

sample for analysis

Notes: The maps plot forest disturbances detected by PRODES and DETER in the 2006 through 2014 period. Sub-figure (a) shows deforested area captured in PRODES, which detects clearings larger than 6.25ha; sub-figure (b) shows forest clearing alert area captured in DETER, which detects clearings and degraded areas larger than 25ha. Dimmed regions are non-sample areas for the analysis in Chapter 2 (see Section 2.4.3 for sample definition). Data sources: PRODES/Inpe (deforestation); DETER/Inpe (alerts); IBGE (Legal Amazon, Amazon biome). 
years of law enforcement data, the analyses use pre-shift PRODES data. This sets 2014 as the sample's final year.

\section{B.1.2}

\section{Monitoring Deforestation and Degradation}

DETER is a satellite-based system, developed and operated by Inpe, that provides near real-time identification of forest clearing activity. Like PRODES, DETER compares current satellite images with earlier ones, scanning for changes in forest land cover. Upon detection, potential forest disturbances map onto georeferenced alerts signaling areas of forest clearing activity. These alerts are sent to the environmental law enforcement authority and serve as the basis for targeting Amazon law enforcement.

DETER builds on the PRODES system to the extent that it only scans for forest disturbances outside the PRODES mask. The bottom panel in Figure B.1 illustrates the procedure: DETER needs year 1 input from PRODES (deforested area in year 1, labeled $\mathrm{A}$ in the figure); in year 2, the system looks for signs of disturbance in forest areas outside the PRODES mask and issues deforestation hot spot alerts accordingly; at the end of year 2, PRODES will either confirm or reject deforested status for these areas, and only those that are confirmed are incorporated into the PRODES mask; in year 3 and beyond, the process repeats itself, with DETER always looking for signs of forest disturbance in forest areas outside the mask.

DETER covers the full extent of the Brazilian Legal Amazon, but only detects signs of disturbance in areas classified as forest in PRODES; again, cerrado areas are not included. It originally used images from the MODIS sensor on the Terra satellite, which has a spatial resolution of $250 \mathrm{~m}$. The system can therefore only detect forest clearings larger than 25 ha. This relatively poor spatial resolution was compensated by both increased temporal frequency (the satellite revisits any given area within the Brazilian Legal Amazon daily) and the ability to detect not only clear-cut deforestation, but also forest degradation. Since 2015, Inpe has operated DETER alongside DETER-B. The new system also serves to issue georeferenced alerts for recent forest degradation and deforestation activity, but it detects changes in land cover in patches larger than 1ha, albeit at lower temporal frequency (Diniz et al., 2015).

Despite its high frequency, DETER data is aggregated at a monthly basis for public release in vector format. DETER was implemented in 2004, but remained in experimental mode through mid-2005. Thus, although a few months of data are available for 2004 and early 2005, consistent remote sensing 
data on DETER alerts only starts in the second half of 2005. The first year of DETER data is therefore set at 2006 throughout the empirical analyses. Figure B.2b plots total alert area during the sample period.

\section{B.1.3}

\section{Mapping Land Use in Deforested Areas}

As PRODES and DETER are land cover classification systems, they provide information on whether natural phenomena covering the Earth's surface have undergone change. Yet, once an area is deforested, whatever happens within that area is regarded as land use. TerraClass Amazônia, a joint effort between Inpe and the Brazilian Enterprise for Agricultural Research (Embrapa), provides land use data for all deforested areas throughout the Brazilian Legal Amazon. The system identifies eleven different land use categories: four types of pasture (grassy, shrubby, exposed soil, under regeneration); cropland (predominantly annual crops); secondary vegetation (detailed in what follows); reforestation (commercial forests of exotic species); urban; mining; mosaic of uses (where no single use can be discerned); and others (a residual category). ${ }^{2}$ If clouds, shadows cast by clouds, or smoke from fires obstruct visibility in imagery, the blocked area is classified as unobservable. For a given year, TerraClass provides current land use data within the full extent of the PRODES mask; that is, within deforested area accumulated through the previous year. It is thus an accumulated, not an incremental, dataset that allows for the identification of transitions across different land uses over time.

TerraClass defines secondary vegetation as areas that were once clear-cut, but currently contain trees and/or shrubs. It includes neither pasture under regeneration, nor commercial reforestation. This category therefore captures tropical regeneration. Figure B.3 shows secondary vegetation mapped in each Amazon state in 2014. Although land use data are now available for 2004 and biannually from 2008 through 2014, they were not processed and released in chronological order. TerraClass 2008 was the first to be released, but only in 2012. Data for 2010 and 2012 followed, and data for 2004 and 2014 were simultaneously released in mid-2016.

As TerraClass uses the same Landsat imagery as PRODES, it has a spatial resolution of $30 \mathrm{~m}$. The data are publicly released in both vector and raster formats at the same original spatial resolution, such that there is no loss of information from operating in either format. ${ }^{3}$ In light of this, and because

\footnotetext{
${ }^{2}$ See Almeida et al. (2016) for a full description of TerraClass classes and methodology.

${ }^{3}$ This is not the case for PRODES, for which raster data are available, but only at lower spatial resolution.
} 
Figure B.3: Regeneration by Amazon State, 2014
(a) Acre
(b) Amapá
(c) Amazonas
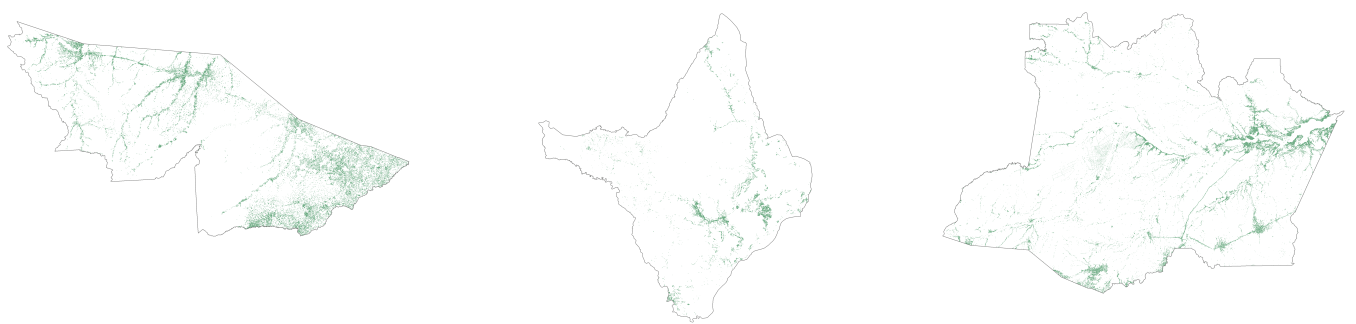

(d) Maranhão

(e) Mato Grosso

(f) Pará
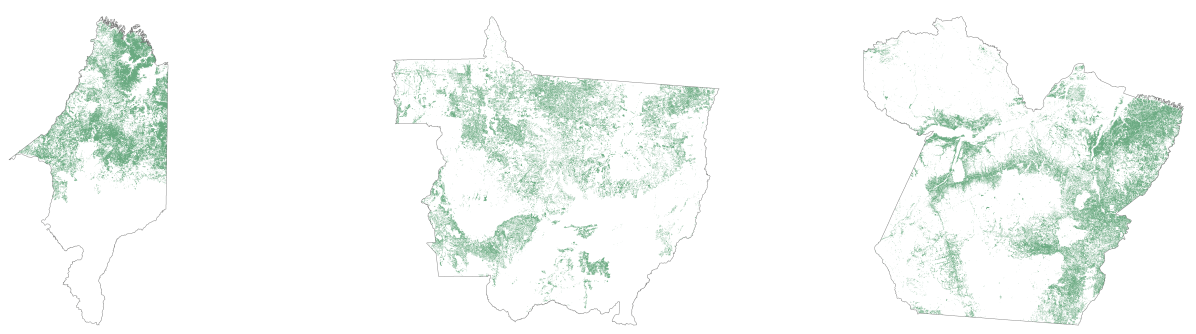

(g) Rondônia

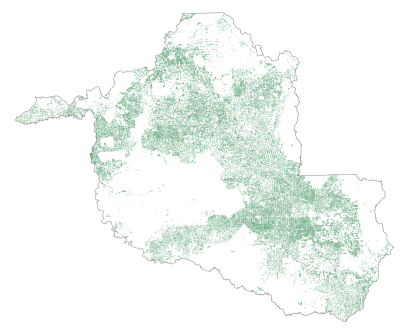

(h) Roraima

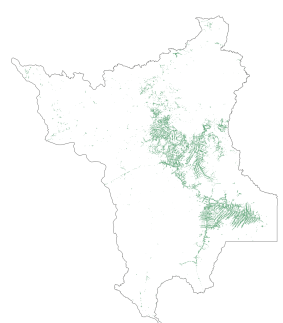

(i) Tocantins

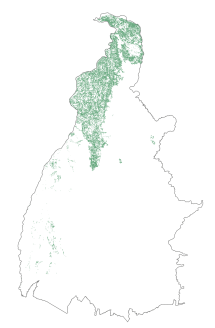

Notes: The maps plot secondary vegetation area by Amazon state in 2014. States are not to scale across sub-figures. Because secondary vegetation patches are small at the sate-level scale, it is difficult to see the difference across years in print. Although available for other years, maps are therefore restricted to 2014 for illustrative purposes only. Data sources: TerraClass/Inpe and Embrapa (secondary vegetation); IBGE (states).

vector data for secondary vegetation are extremely heavy and computationally demanding, datasets for this dissertation use TerraClass raster data.

\section{B.2}

\section{Protected Territory}

FUNAI publicly releases spatial vector data for indigenous lands throughout the country. This dataset contains date variables for each of the indigenous territory recognition stages (see Section 2.2.3), enabling the construction of a georeferenced annual panel. Despite being the official source 
for information on indigenous lands in Brazil, the FUNAI dataset contains several occurrences of missing data for date variables. I address these gaps using information from ISA, which compiles its own historical record of the many recognition stages for indigenous territories. ISA data are publicly available online and were collected using a data-scrapping algorithm. The ISA-based dates fill in the gaps in FUNAI data, but never replace them. Throughout this dissertation, an indigenous land is only regarded as protected when it has completed the declaration stage, at which point its spatial boundaries have been published via ordinance. ${ }^{4}$

Spatial vector data on protected areas come from the Brazilian Ministry of the Environment (MMA). The georeferenced dataset contains information on each area's date of creation and protection type (strictly protected areas or protected areas for sustainable use).

${ }^{4}$ Chiavari et al. (2016) support this cutoff stage, stating that indigenous territories are only protected once they have been declared. 


\section{Appendix C \\ Data Construction}

\section{C.1}

\section{Non-Decreasing Secondary Vegetation}

Although TerraClass has performed well in internal accuracy checks (Salum et al., 2011; Almeida et al., 2010), the classification of forest regrowth is an empirically challenging endeavor. There are two main reasons for this - one inherent to the use of satellite imagery, the other a consequence of the design of Brazil's satellite-based systems. First, because data on secondary vegetation are built from interpretation of satellite imagery, regrowth must be visible in the image to be detected. As imagery is limited by the satellite's spatial resolution, it is plausible to expect that any given deforested area must accumulate sufficient natural biomass to be classified as secondary vegetation. Yet, tropical regeneration is a time-consuming process that may extend over decades (Alves et al., 1997; Aide et al., 2000; Guariguata and Ostertag, 2001). It is therefore likely that areas that are already under regeneration may take several years to show up in satellite-based land use classification systems.

Second, and the focus of this Appendix section, is the fact that Brazil's land use classification system cannot distinguish degraded primary forest from actual secondary vegetation. This is best understood with the help of a simplified illustration of how on-the-ground realities map onto satellite imagery-based land use categories. Figure C.1 represents scenarios for a given area under correct classification and misclassification of secondary vegetation. It indicates how this area is classified under PRODES and TerraClass in each of these scenarios over time. Consider a forested area in the correct classification scenario (Figure C.1a). While left intact (through year $t-1$ in this example), tropical vegetation is classified as forest in PRODES. In year $t$, it suffers clear-cut deforestation and falls under the deforestation increment PRODES category. Starting in year $t+1$, the area is part of the PRODES mask, and is henceforth classified in the TerraClass system. Suppose the area deforested in year $t$ was used as pasture for one year after cleared and then abandoned, allowing regrowth. TerraClass therefore classifies the area as pasture in year $t+1$ and as secondary vegetation from year $t+2$ onwards. 
Figure C.1: Satellite-Based Classification of Regeneration

(a) correct classification: actual secondary vegetation

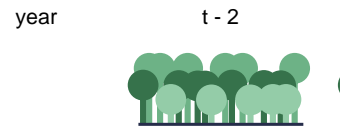

PRODES

TerraClass forest

out of scope

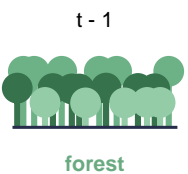

forest

out of

scope

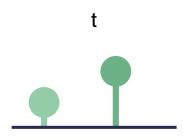

deforestation increment

out of

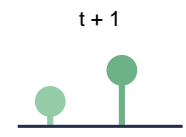

mask

pasture

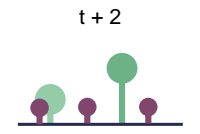

mask

secondary vegetation

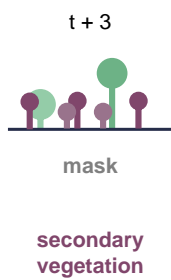

(b) misclassification: degraded primary vegetation

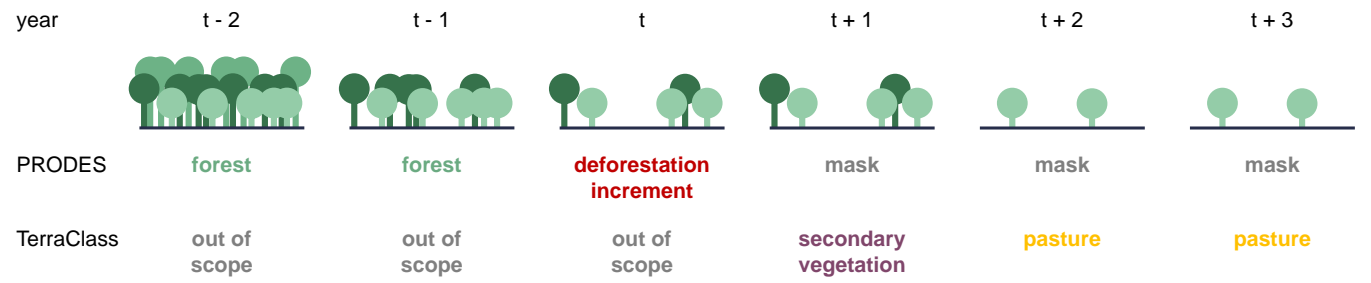

Notes: The figure represents alternative scenarios for correct classification and misclassification of secondary vegetation in satellite imagery. It provides both PRODES and TerraClass categories for a given area over time in each of these scenarios. Panel (a) portrays correct classification. While left intact (through year $t-1$ in this example), tropical vegetation is classified as forest in PRODES. In year $t$, it suffers clear-cut deforestation and falls under the deforestation increment PRODES category. Starting in year $t+1$, the area is part of the PRODES mask, and is henceforth classified in the TerraClass system. Suppose the area deforested in year $t$ was used as pasture for one year after cleared and then abandoned, allowing regrowth. TerraClass therefore classifies the area as pasture in year $t+1$ and as secondary vegetation from year $t+2$ onwards. In this case, the secondary vegetation classification actually captures vegetation that has grown in areas that were once clear-cut - it is therefore correctly classified. Panel (b) portrays misclassification. The vegetation is not left intact, but rather suffers degradation over time through year $t-1$. Yet, because PRODES only detects clear-cut deforestation, early and medium stages of degradation are classified as forest in PRODES through year $t-1$. In year $t$, when it has been sufficiently degraded and has lost enough biomass to look like a deforested area in satellite imagery, it is classified as deforestation increment in PRODES. Again, from year $t+1$ onward, PRODES incorporates this area into its mask, making it available for classification under TerraClass. In year $t+1$, because TerraClass detects vegetation in the deforested area, the remaining (but degraded) primary forest is classified as secondary vegetation. This is consistent with the TerraClass definition for secondary vegetation category - areas that were once clear-cut, but currently contain trees and/or shrubs. The misclassification in TerraClass occurs due to the fact that the area was never clear-cut, thereby violating the assumption that whatever vegetation found in it is tropical regrowth.

This is taken to be correct classification of tropical regeneration, because it captures vegetation that has grown in areas that were once clear-cut.

Now take an alternative scenario in which the forested area is not left intact, but rather suffers degradation over time through year $t-1$ (Figure C.1b). However, because PRODES only detects clear-cut deforestation, early and medium stages of degradation are classified as forest in PRODES. The crucial difference in this scenario is that, in year $t$, the area has not suffered clear-cut deforestation. Instead, it has been sufficiently degraded and has lost enough biomass to look like a deforested area in satellite imagery, at which point it is classified as deforestation increment in PRODES. Again, 
from year $t+1$ onward, PRODES incorporates this area into its mask, making it available for classification under TerraClass. In year $t+1$, because TerraClass detects vegetation in the deforested area, the remaining (but degraded) primary forest is classified as secondary vegetation. Indeed, this is consistent with the TerraClass definition for secondary vegetation category - areas that were once clear-cut, but currently contain trees and/or shrubs. The misclassification in TerraClass occurs due to the fact that the area was never clear-cut, thereby violating the assumption that whatever vegetation found in it is tropical regrowth. This is regarded as a misclassification in quantifying regeneration, because it can overestimate the area covered by secondary vegetation. This is particularly concerning in light of the increasing relevance of tropical degradation, as compared to clear-cut deforestation, in the Brazilian Amazon (Souza Jr. et al., 2013; Rappaport et al., 2018).

In light of this, I draw on the biophysical nature of forest processes to propose an alternative measure of secondary vegetation that is arguably less vulnerable to misclassification errors. While an area under regeneration typically sees an increase in biomass over time, one under degradation sees the opposite trend. It is thus likely that, as degradation continues, a given area will eventually cease to look like secondary vegetation and will be classified in TerraClass according to some other use, like pasture. In Figure C.1b, this is shown starting in year $t+2$. Considering that the permanence of secondary vegetation status differs across scenarios of correct versus incorrect classification, I use it as the basis for building a more conservative measure of tropical regeneration, which I call "non-decreasing secondary vegetation". This measure only considers an area as containing tropical regrowth if it meets two criteria: (i) once classified as secondary vegetation, it never ceases to be secondary vegetation; and (ii) it has been classified as secondary vegetation for at least two consecutive TerraClass years. The first criteria aims at avoiding the misclassification depicted in Figure C.1b. The only exception to this rule is for areas in which satellite visibility is compromised by visual obstructions, as these do not indicate a change in land use, but a technical limitation in the imagery interpretation system. Thus, unobservable is the only non-regeneration TerraClass category that does not break secondary vegetation permanence. The second criteria sets a stringent filter for regeneration by ignoring all areas that have no panel history of regeneration status and can therefore not be duly assessed in terms of permanence. Non-decreasing secondary vegetation areas are regarded as such from the first time they appear as secondary vegetation. The classification algorithm detects permanence by using the full (five-year) 
Figure C.2: Non-decreasing Secondary Vegetation Classification Algorithm

\begin{tabular}{|c|c|c|c|c|c|c|}
\hline \multicolumn{5}{|c|}{ TerraClass category } & \multicolumn{2}{|c|}{$\begin{array}{l}\text { minicell classified as non-decreasing } \\
\text { secondary vegetation in ...? }\end{array}$} \\
\hline 2004 & 2008 & 2010 & 2012 & 2014 & 2004 & 2014 \\
\hline sec. veg. & sec. veg. & sec. veg. & sec. veg. & sec. veg. & yes & yes \\
\hline sec. veg. & sec. veg. & unobserved & unobserved & sec. veg. & yes & yes \\
\hline forest & forest & sec. veg. & sec. veg. & sec. veg. & no & yes \\
\hline forest & sec. veg. & unobserved & unobserved & sec. veg. & no & yes \\
\hline forest & sec. veg. & unobserved & unobserved & unobserved & no & yes \\
\hline pasture & pasture & sec. veg. & sec. veg. & sec. veg. & no & yes \\
\hline sec. veg. & sec. veg. & pasture & pasture & pasture & no & no \\
\hline sec. veg. & sec. veg. & pasture & pasture & sec. veg. & no & no \\
\hline forest & pasture & sec. veg. & sec. veg. & pasture & no & no \\
\hline forest & sec. veg. & unobserved & unobserved & pasture & no & no \\
\hline forest & forest & forest & forest & sec. veg. & no & no \\
\hline
\end{tabular}

Notes: The figure presents possible land use classification histories at the raster minicell level over time and indicates how the decision algorithm classifies non-decreasing secondary vegetation minicell status in 2004 and 2014 based on this history. Land use categories refer to the 30m raster minicell. "Sec. veg." stands for secondary vegetation; pasture is used here merely as an example of a non-regeneration land use category that would be visible in satellite imagery, but the algorithm applies to all observable non-regeneration categories.

TerraClass time series to construct indicator variables that capture whether the $30 \mathrm{~m}$ raster minicell contained non-decreasing secondary vegetation in 2004 and 2014. ${ }^{1}$ Figure C.2 summarizes the history-based decision algorithm.

Although the assessment of forest regrowth in Chapter 3 looks at the 2004 through 2014 cross-sectional difference in the extent of secondary vegetation, classification of non-decreasing secondary vegetation is based on high-resolution raster minicell data spanning the complete TerraClass historical series, and not just sample beginning and end data points. Moreover, because temporal permanence is the key classification criteria, non-decreasing secondary vegetation likely excludes fallow lands containing tropical regrowth. This increases the likelihood that the proposed measure capture secondary vegetation that grows as a result of the abandonment of deforested areas, and not as part of an agricultural production cycle (Vieira et al., 2003; Perz and Walker, 2002). Hence, if a minicell is classified as non-decreasing secondary vegetation, there is a greater chance that it actually does contain tropical regeneration. In this sense, non-decreasing secondary vegetation measure is a more stringent and, thus, more conservative definition for regeneration.

\footnotetext{
${ }^{1}$ The age of secondary vegetation could also be used as a measure of the likelihood of an area classified as secondary vegetation being actual regeneration versus degraded primary vegetation. To the best of my knowledge, these data are not available for the Brazilian Amazon.
} 